


\section{UNIVERSITV CF ILLINOIS : DRARY \\ AT URBANA-CHAMPAIGN \\ (. OLOGY}





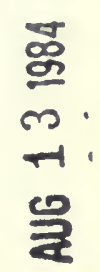






\section{0 \\ FIELDIANA \\ Geology}

Published by Field Museum of Natural History

Volume 40

British Carboniferous Malacostraca

FREDERICK R. SCHRAM

February 23, 1979 



\title{
FIELDIANA: GEOLOGY
}

\author{
A Continuation of the \\ GEOLOGICAL SERIES \\ of
}

FIELD MUSEUM OF NATURAL HISTORY

VOLUME 40

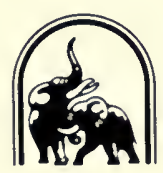

FIELD MUSEUM OF NATURAL HISTORY CHICAGO, U.S.A. 

British Carboniferous Malacostraca 



\section{FIELDIANA Geology}

Published by Field Museum of Natural History

Volume 40

\section{British Carboniferous Malacostraca}

\section{FREDERICK R. SCHRAM}

Department of Zoology

Eastern Illinois University

and

Research Associate

Field Museum of Natural History

Present address:

Department of Paleontology

San Diego Natural History Museum

February 23, 1979

Publication 1293 
Dedicated to my wife, Joan, without whose assistance, encouragement, and cheap-but-nutritious meals this work could not have been undertaken and completed 


\section{FOREWORD}

The following delightful passage comes from the Rev. T. Brown (1861, p. 394) and illustrates the philosophic and theologic ecstacies engendered by the study of fossil shrimp. It is offered here as a classic bit of Victoriana, if not of strict science.

"A single remark of a general kind I may be permitted to offer. One of the most delightful passages in PALEY's "Natural Theology" is his description of the shrimp, and the proof of the goodness of God in communicating such manifest enjoyment of life to these lower orders of being, diffusing such happiness among myriads of His creatures. When we look back into the old creations of geology with their predaceous races, covered with bony armature, and furnished with instruments of destruction so formidable, we are ready to feel as if the world must have been a scene only of darkness and terror; yet the light of God's love must have shone then as now, and perhaps the little crustacean here before us may give some indication of this truth. If PALEY can stand on our modern shores, and, amidst the social instincts of its shrimps, can point to the fulness of their enjoyment as a proof of the goodness of God, I know not why, in the little Gampsonyx of these primeval rocks, evidently not less social in its instincts, we may not read the same lesson, and feel that then of old, as now, the world which He had made bore witness that 'God is love'." 



\begin{abstract}
The British Carboniferous malacostracan fauna is reviewed and a revision of the Hoplocarida and Eumalacostraca of that fauna is presented. No detailed revision of Phyllocarida is attempted with the exception of the Hoplostraca. Four new genera and three new species are described. Twenty-one species constitute the fauna: $A n$ thracocaris scotica, Anthracophausia dunsiana, Bairdops elegans, Belotelson traquairi, Crangopsis eskdalensis, C. socialis, Joanellia elegans, Kallidecthes eagari, Minicaris brandi, Palaeocaris retractata, Perimecturus parki, Pleurocaris annulatus, Praeanaspides praecursor, Pseudogalathea macconochiei, Pseudotealliocaris etheridgei, Pygocephalus cooperi, P. dubius, Sairocaris elongata, Tealliocaris woodwardi, Waterstonella grantonensis, and a possible tyrannophontid stomatopod ("Perimecturus" pattoni).
\end{abstract}


Library of Congress Catalog Card No.: 77-94677

ISSN 0096-2651

PRINTED IN THE UNITED STATES OF AMERICA 


\section{TABLE OF CONTENTS}

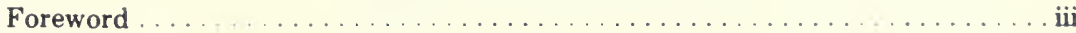

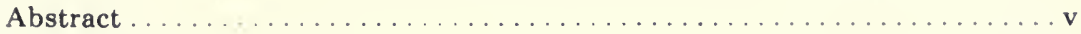

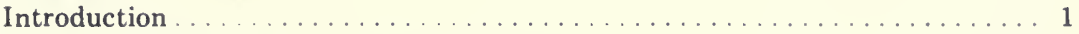

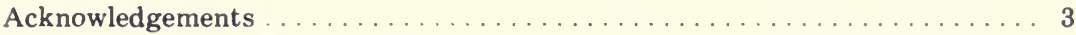

Stratigraphy and register of localities ................... 5

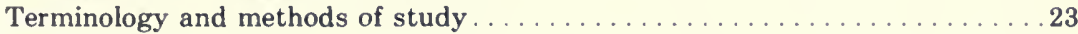

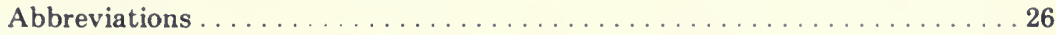

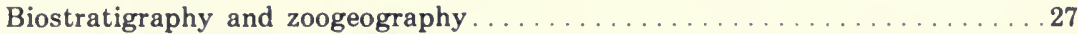

Systematic Descriptions . . . . . . . . . . . . . . . . . . . . 33

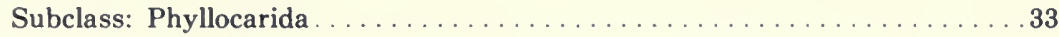

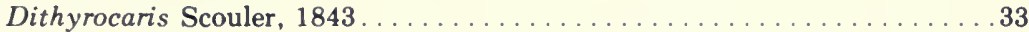

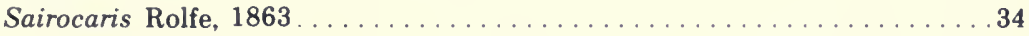

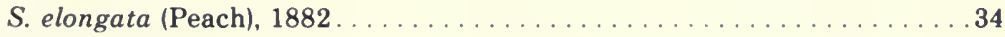

Subclass: Hoplocarida . . . . . . . . . . . . . . . . . . . . . . . . 39

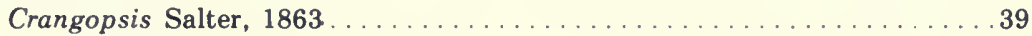

C. socialis (Salter), $1861 \ldots \ldots \ldots \ldots$. . . . . . . . . . . . . . . . . . . 40

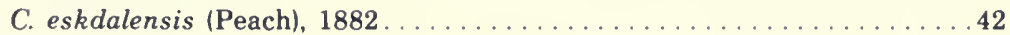

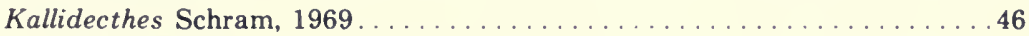

$K$. eagari sp. nov.......................... 46

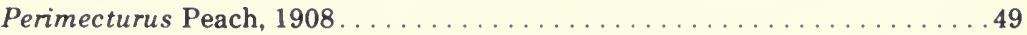

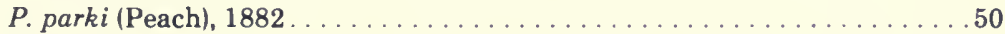

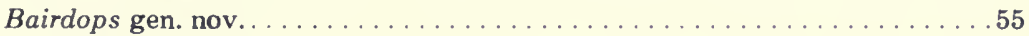

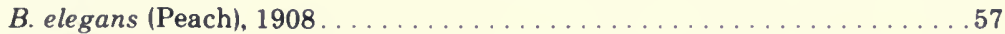

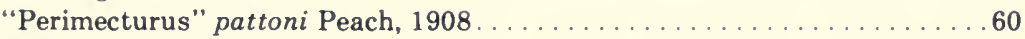

Subclass: Eumalacostraca ...........................61

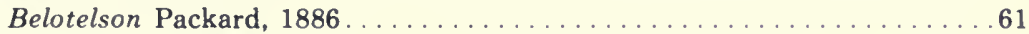

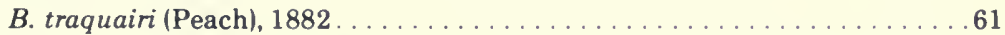

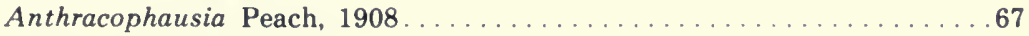

A. dunsiana Peach, 1908 . . . . . . . . . . . . . . . . . . . .67

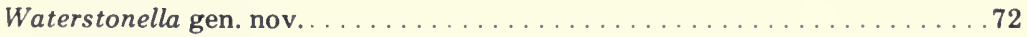

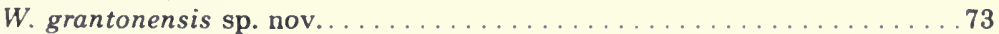

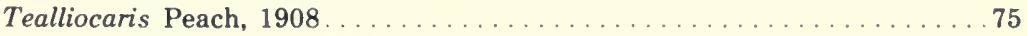

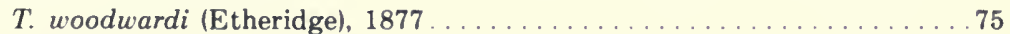

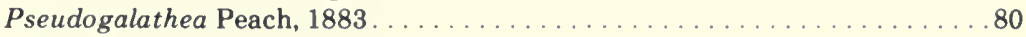

P. macconochiei (Etheridge), 1879 . . . . . . . . . . . . . . . 80

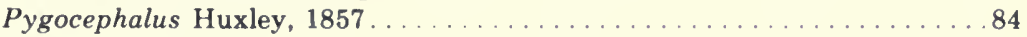

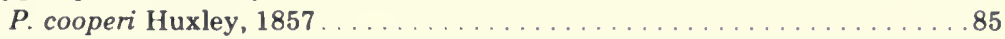

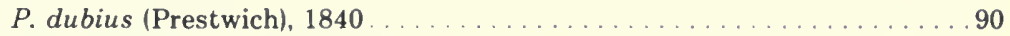

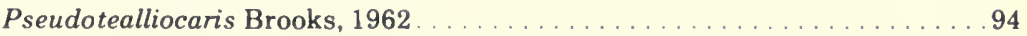

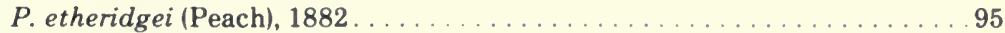

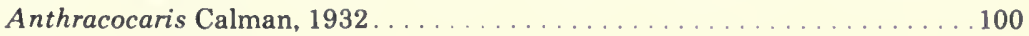

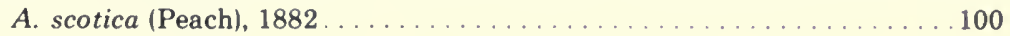


iix

Pleurocaris Calman, 1911.............................103

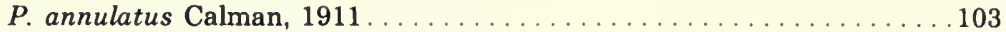

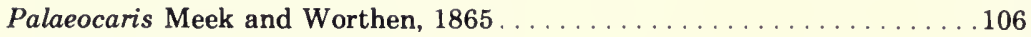

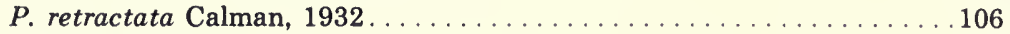

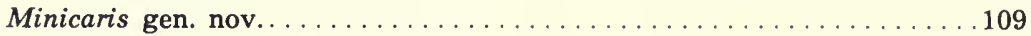

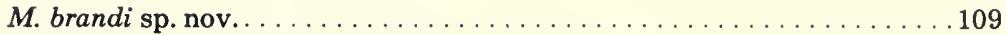

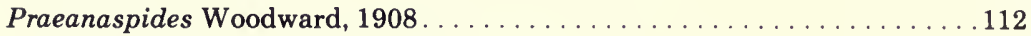

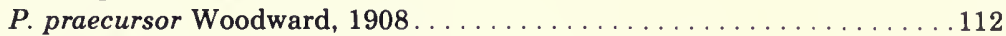

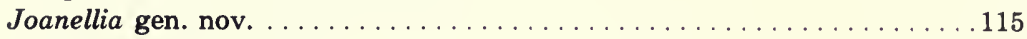

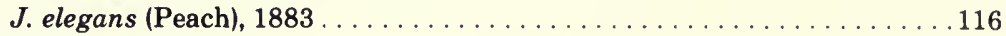

Materials . . . . . . . . . . . . . . . . . . . . . . . . . . . . . 119

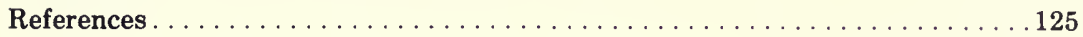




\section{INTRODUCTION}

The British Carboniferous Malacostraca have been known since 1840 when Prestwich named Apus dubius. Since that time some 52 species have been named-the peak of this activity occurring in 1908 when B. N. Peach monographed the Carboniferous Malacostraca of Scotland. Yet these crustacean forms have never been considered important aspects of the Late Paleozoic fauna, nor were they thought to occur too frequently. This despite the fact that the appearance and early evolution of the Malacostraca coincides with the decline and eventual disappearance of the trilobites and the eurypterids-two important groups of marine arthropods of the Early Paleozoic-and that Paleozoic malacostracans are quite common in the near-shore marine and brackish to freshwater facies in which they occur.

The reason for this neglect probably lies in the chaotic state of Paleozoic higher malacostracan taxonomy. This monograph provides a single concise work of reference on the British Carboniferous higher malacostracans.

Several problems have been encountered in the course of this study which must be enumerated for a proper understanding of this monograph and the manner in which it was prepared.

First, and most disconcerting, is the large number of named taxa. Most of the Paleozoic eumalacostracans were described in the late 1800 's when slight variations in morphology, size, or preservation frequently served as a basis for a specific or generic definition. For example, Peach (1908) recognized three species of his 1883 genus Pseudogalathea, which appear to be merely size and preservational variants of one form. This practice stemmed in part from the fact that these early workers were geologists with little or no background in biology or knowledge of extant species. This lack of background can be clearly seen in the work of Peach. Subsequent to the publication of G. O. Sars' (1895) monograph on the Challenger Expedition schizopodous malacostracans, and W. T. Calman's 
(1897) discussion of the first extant syncarid, Anaspides tasmaniae, Peach (1908) was able to see his Carboniferous animals in a new light and made constant comparative and pictorial references to living forms in relation to the fossils in his monograph.

The reliability of previous observers has varied widely. My examination of actual specimens and comparison with original descriptions by some of these men usually showed good correspondence (though there may have been some questions about interpretation or taxonomic placement which are related to better understanding with time rather than defects in original observations). In contrast, on some specimens it was impossible to see such structures as statocysts, luminescent organs, or genitalia reported by Peach (1908). Disintegration of fossil specimens with time is known to occur, especially if pyrite is present. Some of the original localities have continued to produce over the years, and specimens collected by me are of equal or better preservation than those found in the 1800's. Brooks (1962b) presented some reconstructions of British Carboniferous shrimp based on study of the literature, but these have not proved entirely adequate. For example, the reconstruction of Perimecturus elegans which Brooks offers is based on material I believe encompasses two species in two separate genera. Brooks (1969) subsequently examined the British material but has published only a summary.

There is also a problem in locating some types of the British Malacostraca. For instance, those of Peach's species Crangopsis magna, C. minuta, and C. hastata are missing. Peach apparently had a habit of giving specimens away either for trade or as gifts. Whether the missing specimens were given away or simply misplaced in some museum collection is not known. Some species were described from specimens in private collections (for example, Woodward's species Palaeocaris burnetti and Anthrapalaemon grossarti holti) which were never deposited in a museum and have since been dispersed and lost. Efforts to trace them have not been successful.

Another problem arises in attempting to relate a part of an animal, especially when poorly preserved, to whole individuals. Peach (1908) described several rather poorly preserved shrimp tails. The whole genus Paleomysis includes only species known from tails, as is true of the species Crangopsis hastata. It is difficult to associate a poorly preserved tail named Paleomysis dunlopi with any of six or seven species which are based on whole specimens from the Glencartholm Volcanic Beds in which it occurs. 


\section{ACKNOWLEDGEMENTS}

A monograph of this kind can not be produced without the assistance and co-operation of many people.

Several, however, deserve special mention. Heading the list is my wife, Joan, who did most of the photographic and record-keeping work. Dr. Charles Waterston, Keeper of Geology, Royal Scottish Museum, extended the hospitality and use of the facilities of that institution and Mr. William Baird, Assistant Curator of Fossil Invertebrates there, assisted in pinpointing locality coordinates. Dr. Euan Clarkson, University of Edinburgh, helped explore some of the old collecting localities in Scotland. Mr. Peter Brand, Institute of Geological Sciences (I.G.S.), Edinburgh, was untiring in locating material in that collection of both recognized and all-but-forgotten localities with fossil crustaceans. Dr. William Ramsbottom, I.G.S., Leeds, helped on matters concerning the English Coal Measures localities. Dr. Michael Eagar, Manchester University Museum, was of great help on questions of faunistics and stratigraphy and in trying to locate lost private collections (this last, was, alas, unsuccessful though not through lack of his efforts).

Other people to be thanked include Professor Harry Whittington, Cambridge University; Dr. Robert Wilson and Mr. Douglas Graham, I.G.S. Edinburgh; Ms. D. M. Gregory, I.G.S. Leeds; Dr. Richard Fortey and Mr. Sam Morris, British Museum (Natural History); Dr. Ian Rolfe, Hunterian Museum, Glasgow; Messrs. Charles Palmer and Euan Campbell, Kelvingrove Museum, Glasgow; Mr. Peter Dickson, Manchester University; Dr. I. Strachan, Birmingham University; Mr. H. P. Powell, Oxford University; Mr. Ian Morrison, Dick Institute, Kilmarnock; Dr. Michael Bassett, National Museum of Wales; Dr. Alex Livingston and Messrs. Robert Reekie, John Evans, and George Holliday of the Royal Scottish Museum; the personnel in the map room of the National Library of Scotland; Mr. Harley Holt, Eastern Illinois University; and Dr. Adrian Rushton, I.G.S., London. 
The following people saw all or chapters of the manuscript and offered constructive criticism: Prof. Whittington, Dr. W. W. Black, P. Brand, E. N. K. Clarkson, W. H. C. Ramsbottom, W. D. I. Rolfe, W. W. A. Rushton, C. Waterston, R. B. Wilson, and J. M. Schram. Mr. Mark Drone was of technical assistance in assembling the final figures and manuscript.

Eastern Illinois University contributed funds toward the publication of this monograph. 


\section{STRATIGRAPHY AND REGISTER OF LOCALITIES}

A great deal of effort is being made by members of the Institute of Geological Sciences to attain solutions to various problems of interbasin correlations. This paleontological monograph, however, is not the place to deal with such stratigraphic issues still in flux. An effort has been made to incorporate some of the latest stratigraphic information, with the assistance of I.G.S. personnel. But the wellknown chart of Francis in Craig (1965, p. 344) is used as a point of reference in this monograph (fig. 1). The old localities in the literature can be more easily fitted into such a stratigraphic scheme which will later afford a basis for comparison of faunas both within and without Britain.

An effort has been made to assemble information on localities where Carboniferous Malacostraca were found. This was done for several reasons. First, there was an obvious benefit for this monograph as being a useful reference work. Second, there was a need to establish a framework for determining stratigraphic positions as well as geographic locality. Third, by combining stratigraphic with taxonomic information one could decide the possible identity of poorly preserved or fragmentary specimens from the same or stratigraphically equivalent localities.

The localities given in the literature were used as a basis. Grid coordinates were determined from Ordinance Survey sheets (7th ed.). Many of the localities noted by me on museum labels have not been previously mentioned in the literature. The localities given are the most explicit that can be taken from labels, registers, field notes, and/or map co-ordinates. The personnel at the Institute of Geological Sciences in Edinburgh and Leeds were of great assistance in this effort, as well as Mr. William Baird of the Royal Scottish Museum and Dr. Michael Eagar of the Manchester Museum.

Numbers are given to each locality for convenient reference. The numbers tend to be grouped geographically and are used in reference in the text and materials listings. 


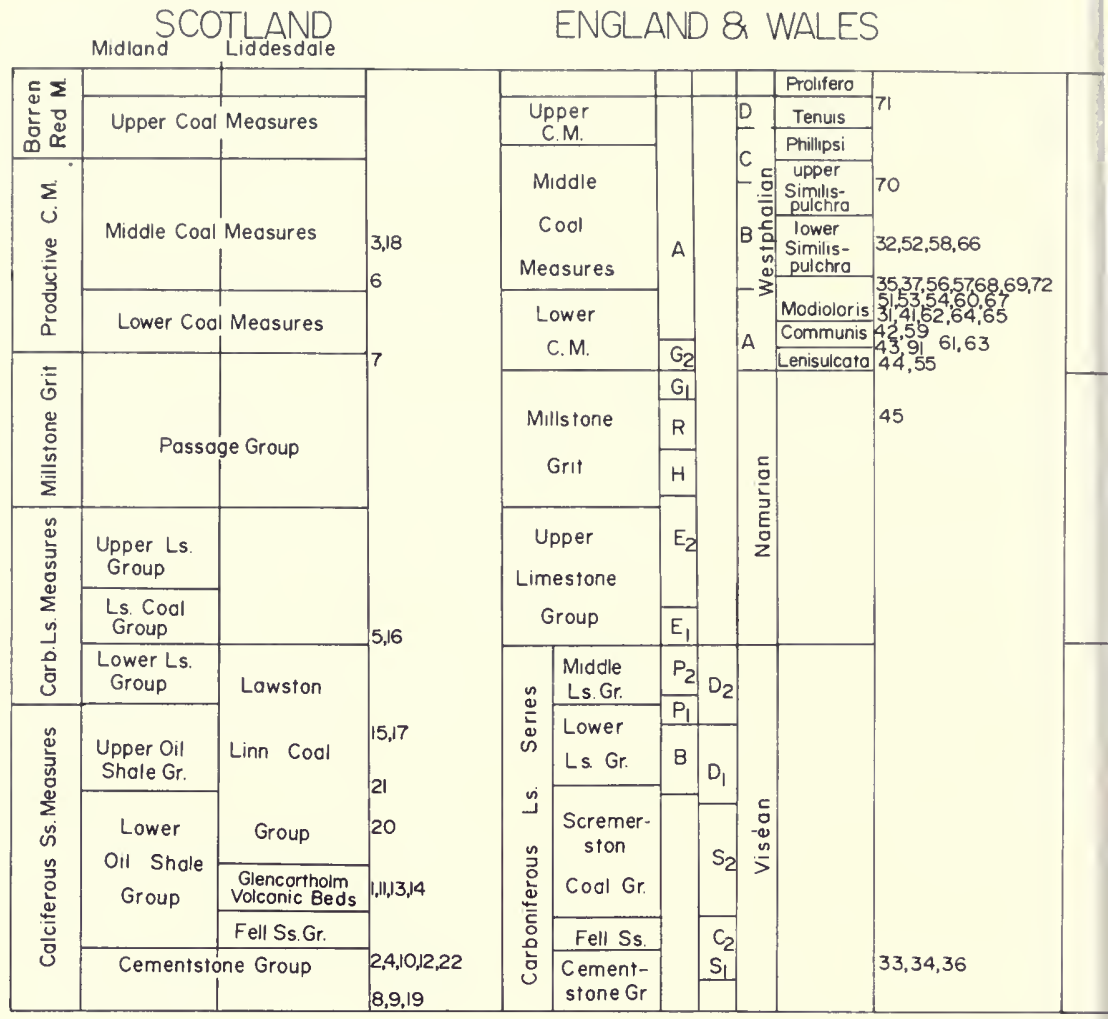

6 


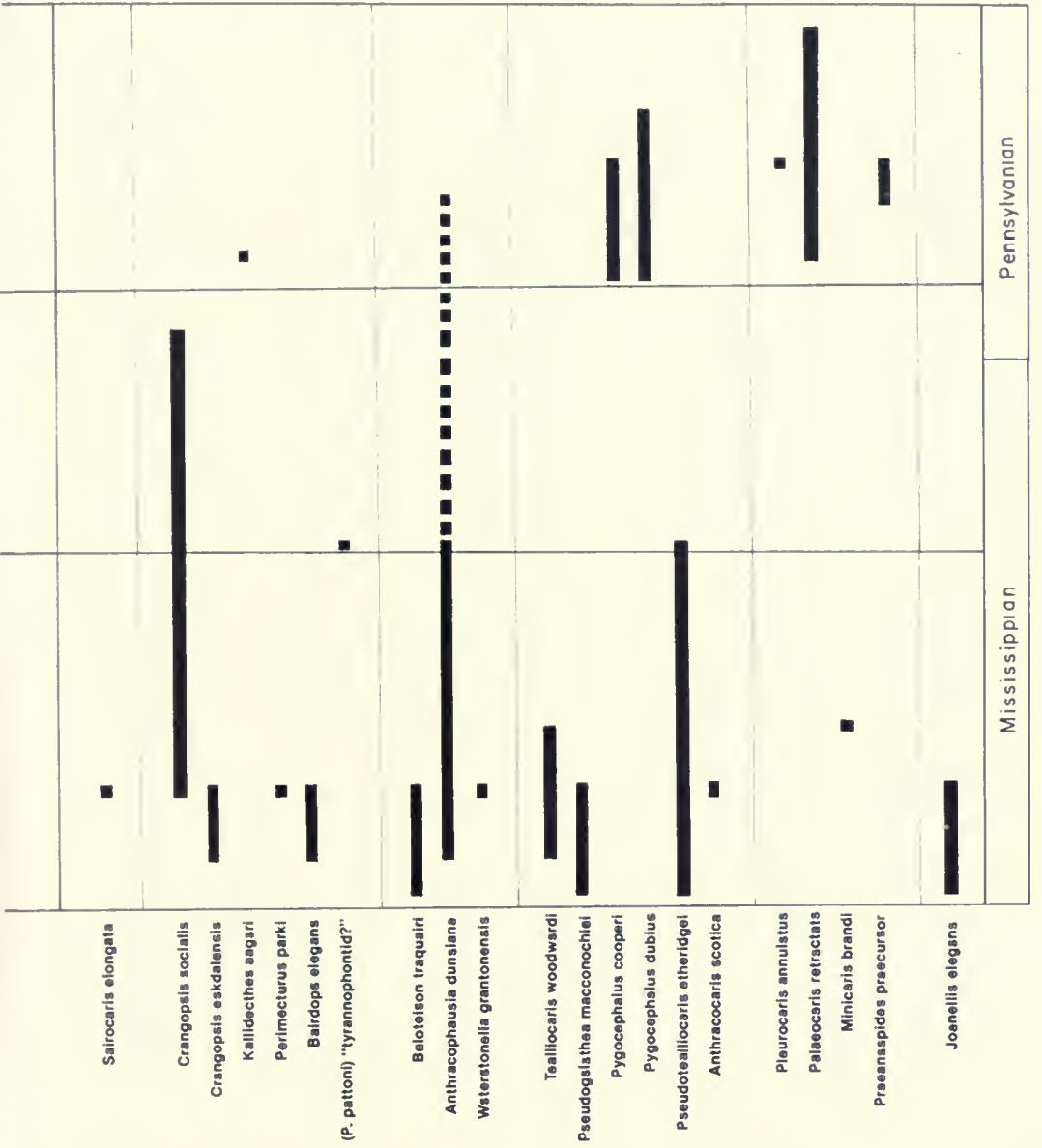

FIG. 1. Stratigraphic position of the localities with British Carboniferous malacostracans with the stratigraphic ranges of species. Stratigraphic chart modified from Francis, table 92, in Craig (1965). For explanation of locality numbers, refer to register of localities. 
When appropriate information existed on associated faunas other than malacostracans I have appended such as "remarks" to the locality concerned. Presence of holotype $\left(^{*}\right)$ or lectotype $(* *)$ is designated in the faunal lists which follow.

1. Locality. -River Esk (NY 3779), Glencartholm, 11/2 miles below Langholm, Dumfriesshire.

Stratum.-Glencartholm Volcanic Beds (many specimens from the "scorpion bed"), Lower Oil Shale Group (Upper Border Group), Calciferous Sandstone Measures, Dinantian.

Fauna.-Percentage of species from a census of the collections of Glencartholm of the I.G.S., Edinburgh.

Sairocaris elongata**

Crangopsis eskdalensis** $28.7 \%$

Perimecturus parki**

$6.4 \%$

Bairdops elegans**

Belotelson traquairi** $7.0 \%$

Anthracophausia dunsiana

Pseudogalathea macconochiei

$6.4 \%$

Pseudotealliocaris etheridgei**

$1.8 \%$

Anthracocaris scotica**

$22.5 \%$

Joanellia elegans **

Remarks. - This is perhaps the most important assemblage for fossil crustaceans in the British Carboniferous, the fauna being rich and well preserved. It approached such famous North American assemblages as the Mazon Creek faunas of the Illinois Pennsylvanian or Bear Gulch fauna of the Montana Mississippian, and combined with these will be of considerable importance in understanding malacostracan evolution.

The Glencartholm beds were characterized by Lumsden et al. (1967) as composed of interbedded tuffs, sediments, and tuffaceous sediments. Lavas are at the base and the sediments are shales and mudstones with bands of limestone and cementstone, a few thin sandstones and one or two coals with seat-earth underclays.

The fauna is basically marine with some terrestrial elements in distinct beds. Peach and Horne (1903) point out that the diverse fauna and fine preservation are found only in this one of several exposures of the Glencartholm Volcanic Beds. The fossils seem to occur in distinct associations in particular beds, e.g., the fish and crustaceans are typically found underneath a band in which Orthoceras is 
conspicuous. Scorpions and plants seem to predominate in a separate bed. The ferns are typically encrusted with calcite and the crustaceans are sometimes filled with a calcium salt, as if the water in which they were deposited was high in $\mathrm{CaSO}_{4}$. This would seem to indicate that the Glencartholm sea was open to a main marine habitus but was perhaps periodically cut off from that sea as an evaporite lagoon.

A complete faunal list is given by Peach and Horne (1903, pp. 846, $847)$ and is reproduced in part here with generic emendations:

plants: Bythotrephis (4 spp.), Calymmatotheca bifida, Sphenopteris (6 spp.), Rhodea machaneki, Rhacopteris (2 spp.), Cardiopteris polymorpha, Eskdalia minuta, Asterocalamites scrobiculatus, Volkmannia sp., Lepidodendron veltheimi, Lepidophyllum lanceolatum, Lepidostrobus variabilis, L. fimbriatus, Carpolithes sp., Ptilophyton plumula.

Ostracoda: Beyrichia gigantea.

Merostomata: Cyrtoctenus (Glyptoscorpius), Cyclus testudo, Euproops rotundata.

Arachnida: Eoscorpius euglyptus, E. glaber, E.sp.

Brachiopoda: Discina nitida, Lingula mytiloides, L. squamiformis, L.sp., Productus semireticulatus, small adherent brachiopod.

Pelecypoda: Abiella (Posidonomya) radiata, Aviculcpecten geikiei, A. eskdalerisis, $A$. interstitialis, $A$. papyracea, A. planicostatus, A.sp., Edmondia josepha, E.sp., Entolium sowerbyi, Leiopteria divisa, Lithodomus carbonarius, Modiolus macadami, Myalina sublameliosa, M.sp., Pinna mutica, Pteronites angustatus, Sanguinolites variabilis, Sedgwickia ovata.

Gastropoda: Euomphalus catillus, E. pentangulatus, Murchinsonia sulcata, Naticopsis plicistria.

Cephalopoda: Orthoceras sp.

Conulariata: Conularia quadrisculcata.

Chordata: Acanthodes nitidus, Acrolepis ortholepis, Canobius elegantulus, Cheirodopsis geikiei, Chondrenchelys problematica, Cladodus sp., Coelacanthus huxleyi, Cyclotychius concentricus, Elonichthys pulcherrimus, E. serratus, Eurynotus spp., Mesolepis rhombus, $M$. tuberculatus, Mesopoma politum, M. pulchellum, M. ramsayi, Phanerosteon mirabile, Platysomus superbus, Rhadinichthyes augustulus, $R$. delicatulus, $R$. fusiformis, $R$. mac- 
conochiei, $R$. tuberculatus, Sphenacanihus costellatus, Strepso-

dus spp., Tarrasius problematicus, Tristychius minor.

2. Locality.-Foot of Tarras Water (NY 3881), Langholm, Dumfriesshire.

Stratum.-Cementstone Group, Calciferous Sandstone Measures.

Fauna.-Tealliocaris woodwardi

Remarks.-This locality marks the lowest occurrence of this species.

3. Locality.-Greenhill or Woodhill Quarry (NS 4039), near Kilmaurs, Ayrshire

Stratum.-Roof of Finnies Main Coal, Middle Coal Measures, Westphalian B.

Fauna.-Pygocephalus cooperi

Praeanaspides praecursor

Remarks.-Though generally in concretions, the fossils of this locality are rather poorly preserved.

4. Locality.-Tweeden Burn (NY 4887), near junction with Liddel Water, one-half mile below Newcastleton, Roxburghshire.

Stratum.-Cementstone Group, Calciferous Sandstone Measures, Dinantian.

Fauna.-Bairdops elegans

Teallicocaris woodwardi

Pseudogalathea macconochiei*

?Pseudotealliocaris etheridgei

Remarks. - The assemblage list of Peach and Horne (1903, p. 842) includes several lamellibranch pelecypods which they interpreted as an indication of mudflat, estuarine conditions. Jones and Woodward (1888-1899) record Dithyrocaris here.

5. Locality. -East Kilbride (NS 6655), Lanarkshire.

Stratum. - "Shale over the Cement Limestone" (this is probably the Top Hosie Limestone at base of stage $E_{1}$ ), Limestone Coal Group, Carboniferous Limestone Measures, Namurian.

Fauna.-"Perimecturus" pattoni

Anthracophausia dunsiana

Pseudotealliocaris etheridgei 
Remarks.-Jones and Woodward (1888-1899) report the phyllocarid Dithyrocaris.

6. Locality.-Airdrie area, Lanarkshire.

Stratum.-Softband Ironstone, $5 \mathrm{ft}$. below the Airdrie Blackband, just above Queenslie Marine Band, Middle Coal Measures, Westphalian B.

Fauna.-Pygocephalus dubius

?Anthracophausia dunsiana (tail fragments)

Remarks. - There are several possible localities in the Airdrie area these fossils may have come from. Several collieries are candidates: Stanrigg (NS 7968), Greyrigg (NS 7969), and Greengairs (NS 7970). The literature has several variations for this locality (or localities): "Greengairs, 3.5 miles NNE of Airdrie," "Old Pit Racecourse," "Coal Fields, Airdrie," "Upper Coal Measures, Airdrie." It is likely that several sites are involved, all of them relating to one stratum. This is one of many localities with "?A. dunsiana," i.e., parts of telsons and abdomens (with no attached whole animals) which look like those of $A$. dunsiana of the Lower Carboniferous.

7. Locality.-Goodock Hill (NS 8161), Shotts, Lanarkshire.

Stratum.-Slaty Ironstone, top of the Passage Group, Westphalian A.

Fauna.-Pygocephalus dubius

8. Locality.-Whiteadder Water (NT 8056), Broomhouse, Duns, Berwickshire.

Stratum.-Lower Cementstone Group, Calciferous Sandstone Measures.

Fauna.-Belotelson traquairi

Pseudotealliocaris etheridgei

Joanellia elegans

Remarks. - This and the next locality (no. 9) are the lowest crustacean localities in the British Carboniferous.

9. Locality.-Whiteadder Water (NT 878546), three-quarters mile below Allanton, Berwickshire.

Stratum.-Lower Cementstone Group, Calciferous Sandstone Measures, Dinantian. 


\section{Fauna.-Pseudotealliocaris etheridgei}

10. Locality.-River Tweed (NT 856411), Coldstream, Berwickshire.

Stratum.-Cementstone Group, Calciferous Sandstone Measures.

Fauna.-Crangopsis cf. eskdalensis

Tealliocaris woodwardi

11. Locality. - Cheese Bay (NT 4985), near Gullane and Archerfield, East Lothian.

Stratum. - Wardie Shale, Oil Shale Group (Upper Border Group), Calciferous Sandstone Measures.

Fauna.-Tealliocaris woodwardi**

Remarks. - This locality is usually best exposed in midwinter when storms have removed the sand from the outcrop. Pieces of the shale, however, can be picked up as cobbles along the strand line at any time of the year.

12. Locality.-East Belhaven Bay (NT 6578), Dunbar, East Lothian.

Stratum.-Cementstone Group, Calciferous Sandstone Measures, Dinantian.

Fauna.-Tealliocaris woodwardi

13. Locality.-Granton Shore (NT 2277), near Edinburgh, Midlothian.

Stratum. - Wardie Shale, Oil Shale Group, Calciferous Sandstone Measures, Dinantian.

Fauna.-Perimecturus parki??

Waterstonella grantonensis*

Remarks. - The single specimen of $P$. parki (named $P$. stocki by Peach, 1908) is marked "Wardie Shore, near Edinburgh." I assume this is at or near this locality, but the preservation of the specimen and the lithology of the rock is more like that of Glencartholm (locality no. 1).

14. Locality.-Muirhouse (NT 2176), half-way between Granton and Crammond, Midlothian.

Stratum. - Wardie Shale, Oil Shale Group, Calciferous Sandstone Measures. 
Fauna.-Crangopsis socialis

Waterstonella grantonensis

Remarks.-Although old labels indicate a locality at Granton, this really seems to occur farther west at Muirhouse (see locality no. 13). The Granton locality was thought not to exist anymore, having been paved over and the last recovered material sold to the Museum of Comparative Zoology, Harvard University, where it still is (at least as of 1967). But recently Mr. Stanley Wood, who has collected the Granton beds for some years, rediscovered the "shrimp bed," which occurs in an 8-in. shale band within a 3 -ft. limestone horizon. The base of the limestone has few fossils in it, but the top contains crinoids and goniatites. One specimen seems to have a nautiloid associated with the shrimp. Waterstonella appears to mark the beginning of a marine incursion in a non-marine sequence noted for its palaeoniscoid fish.

15. Locality.-Ardross Shore (NO 5000), Fifeshire (different references noted here such as "Ardross Castle" or "Ardross Shore").

Stratum. -Lower Ardross Limestone, Upper Oil Shale Group (Upper Border Group), Calciferous Sandstone Measures, Dinantian.

Fauna._Crangopsis socialis*

16. Locality. - Red Cleuch Burn (NS 65567846), 330 yd. E $33^{\circ}$ of Spouthead, NE of Glasgow, Stirlingshire.

Stratum.-Roof of the Top Hosie Limestone, Limestone Coal Group, Carboniferous Limestone Measures, Namurian.

Fauna.-Crangopsis cf. socialis

Anthracophausia dunsiana (tails)

Remarks. - These crustaceans were found in association with a fauna that contains several types of pelecypod and a strange arthropod leg (possibly an arthropleurid).

This locality is stratigraphically equivalent to the "Paisley" locality of Huxley (1862) from which he described the now-lost type of Crangopsis huxleyi.

17. Locality. -Near St. Monans (NO 5301), Fifeshire.

Stratum.-Upper Oil Shale Group, Calciferous Sandstone Measures, Dinantian.

Fauna.-Crangopsis socialis 
Remarks. - May actually be the same locality as number 15; grid reference given here is for St. Monans.

18. Locality.-Shettleston (NS 6463) (approx. co-ord.), Lanarkshire.

Stratum.-Probably Middle Coal Measures, Westphalian B.

Fauna.-Pygocephalus cooperi.

Remarks.-Information attached to the one specimen from this locality, R 1957.1.5098, is scanty. Several collieries in this area were active when Dunlop, the collector, procured the specimen.

19. Locality. - Mouth of Tyne, (NT 6481) 1 mile E of Tynninghame Links, East Lothian.

Stratum.-Cementstone Group, Calciferous Sandstone Measures, Dinantian.

Fauna.-Pseudogalathea macconochiei

20. Locality. - Long Livingston Borehole no. 25, (NT 040689) 1,071 ft. to $1,151 \mathrm{ft}$. section, West Lothian.

Stratum.-Beds below the Pumpherston Shell Bed, Lower Oil Shale Group, Calciferous Sandstone Measures, Dinantian.

Fauna.-Tealliocaris woodwardi

Minicaris brandi*

Remarks. - This collection was cited in Carruthers (1927, p. 108).

21. Locality. -Carlops Bridge (NT 1656), River North Esk, Peeblesshire.

Stratum.-Toward the top of the Lower Oil Shale Group, Calciferous Sandstone Measures, Dinantian.

Fauna.-Crangopsis cf. socialis

Remarks.-Cited in Mitchell et al. (1962, p. 103). These beds are rich in pyrite. The material is disintegrating badly with time in the collections of the Institute of Geological Sciences, Edinburgh.

22. Locality.-River Tweed (NT 866428), left bank, 2 miles NNE of Coldstream Bridge, E of Lennel Hill, Berwickshire.

Stratum.-Cementstone Group, Calciferous Sandstone Measures, Dinantian.

Fauna.-Crangopsis eskdalensis

31. Locality. - Whitehaven Laundry Borehole (NX 97511679), depth $92 \mathrm{ft}$., Cumberland. 
Stratum. - Lower Coal Measures, Lower Modiolaris Zone, Westphalian A.

Fauna.-Pygocephalus dubius

32. Locality.-Easington no. 9 Upover Borehole (NZ 4971546482), $\mathrm{SE}$ return, 4,800 ft. E of $66 \mathrm{ft}$. fault, depth $212 \mathrm{ft}$., Durham.

Stratum.-Middle Coal Measures, Lower Similis-Pulchra Zone, Westphalian B.

Fauna.-Pygocephalus dubius

33. Locality.-Chattlehope (NT 7302), Rede Water, Northumberland (now possibly under Catcleugh Reservoir).

Stratum.-Cementstone Group, Carboniferous Limestone, Dinantian.

Fauna.-Anthracophausia dunsiana

Pseudogalathea macconochiei

Tealliocaris woodwardi ? (specimens lost, but figured in Peach 1908, pl. 2, figs. 8 and 9).

Remarks.-Examination of the collection at Leeds indicates an associated fauna of clams (Myalina sp., Naiadites obesus, and Modiola oblonga), something labeled "Eoscorpius," Lepidodendron plant material, and a number of unidentifiable arthropod-like things. Jones and Woodward (1888-1899) report Dithyrocaris here.

34. Locality.-Coomsden Burn, (NT 7104), one-half mile above junction with Rede Water, Northumberland.

Stratum.-Cementstone Group, Carboniferous Limestone, Dinantian.

Fauna.-Crangopsis sp.

Pseudogalathea macconochiei

Joanellia elegans

Remarks. - A very extensive fauna is associated with these crustaceans. There are several clams (Modiolus macadami, Cypricardia modiolaris, Naiadites obesus, and Aviculopecten sp.), an orthocerid cephalopod, a productoid (?) brachiopod, crinoid stems, Spirorbis helicteres, Eoscorpius giganteus, Cyrtoctenus ("Glyptoscorpius"), a Rhizodus scale, a fish tooth, and Helodus. The shrimp are generally rather poorly preserved.

35. Locality.-Shore south of Hartley Steps (NZ 342765), Hartley Bay, between Elyth and Tynemouth, Northumberland. 
Stratum.-Shale $6 \mathrm{ft}$. below the Top Hutton Seam, Middle Coal Measures, Westphalian B.

Fauna.-Pygocephalus cooperi

36. Locality.-Hawks Burn (NT 7403), near Catcleugh, Northumberland (probably under Catcleugh Reservoir).

Stratum.-Cementstone Group, Calciferous Sandstone Series.

Fauna.-Joanellia elegans

Remarks. - There are specimens of Strepsodus and Alcicornopteris convoluta associated with the shrimp.

37. Locality.-Tynemouth (NZ 366712), North Point, Northumberland.

Stratum.-Roof of the Hutton Seam, Middle Coal Measures, Westphalian B.

Fauna.-Pygocephalus dubius

41. Locality. - Sinking at Cefn-y-Coed Colliery (SJ 2658) approx. 5 miles NW of Wrexham, $4 \frac{1}{2}$ miles SSE of Mold Station, Flintshire.

Stratum. $-12 \mathrm{ft}$. above the cannel coal, Lower Coal Measures, Lower Modiolaris Zone, Westphalian A.

Fauna.-Pygocephalus cooperi

42. Locality.-Medlock Park Bridge (SD 940025), Ashton-underLyne, Lancashire.

Stratum.-Lower Coal Measures, Upper Communis Zone, Westphalian A.

Fauna.-Pygocephalus cooperi*

43. Locality.-Sparth Bottoms brick quarry (SD 8913), one-half mile W of Rochdale town hall, Lancashire.

Stratum. - Lower Coal Measures in the lower third of the Communis Zone, Westphalian A.

Fauna.-Pygocephalus cooperi

Belotelson?

Remarks. - This assemblage has some interest because of supposed similarity to the Middle Pennsylvanian Mazon Creek, Braidwood faunas of Illinois. There are, however, several points of difference (Eagar, personal communication).

Sparth Bottoms has fossils in ironstone concretions, which come 
from a greyish blue shale between two thin sandstones. There seem to be different faunal horizons within the shale but, because of scattered collecting by different people over the years, exact stratigraphic position of specimens is difficult to establish. A number of non-marine bivalves are associated together in beds. There are a number of arthropods reported from this locality but they may be from different beds than the bivalves. A partial faunal list of Sparth Bottoms is as follows:

Pelecypoda: Carbonicola communis (sensu lato), Naiadites flexuosus, Anthraconaia fugax, Curvirimula trapeziforma, Curvirimula $\mathrm{cf}$. belgica

Annelida: Spirorbis sp.

Ostracoda: Carbonita humilis, Carbonita pungens

Phyllocarida: Dithyrocaris sp.

Merostomata: Belinurus bellulus (and assorted other Woodward species), Euproops spp. (including E. rotundata), a eurypterid, Halicyne (Cyclus) johnsoni

Arachnida: Eoscorpius sparthensis, Geralinura sutcliffei, Anthracomartus trilobitus, Anthracosira woodwardi, Architarbus subovalis, Eoscorpius wardlingeyi

Myriapoda: Xylobius platti, Archiulus sp., Euphoberia (several species), Acantherpestes (several species), Palaeosoma giganteum

Insecta: Stenodictya lobata, Spilaptera sutcliffei, Rochdalia parkeri

Numerous plants and the fish Strepsodus sp. and Ctenodus sp.

Though similar in some ways to the Niazon Creek Braidwood fauna, Sparth Bottoms fauna is not nearly so diverse and has a very strong molluscan element. The Mazon Creek faunas occur in a gray shale directly over a coal.

44. Locality.-Carre Hays (SD 8939), 1 mile SE of Colne, Lancashire.

Stratum.--Soapstone bed, immediately above the Gastrioceras listeri marine band, Lenisulcata Zone, Lower Coal Measures, Westphalian A.

Fauna-Pygocephalus cooperi

Remarks.-Bolton (1905) gave a detailed presentation of the stratigraphy of this site. The faune is not as diverse as that of Sparth Bottoms and contains more vertebrates. A partial list is as follows:

Cephalopoda: Dimorphoceras gilbertsoni 
Merostomata: Euproops rotundata

Arachnida: Architarbus subovalis

Chordata: Hybodopsis wardi, Acanthodes wardi, Elonichthys aitkeni, Hylonomus wildi, unidentified microsaur amphibians.

45. Locality. -1 mile $\mathrm{N}$ of Todmorden (SD 925255), Burnley, Lancashire.

Stratum.-Millstone Grit, probably $\mathrm{R}_{2}$ stage, Marsdenian, Namurian.

Fauna.-Crangopsis socialis

Remarks. - Salter (1861b) had referred to this specimen as Palaeocrangon sp. He had apparently intended to make this a new species since the label reads "Palaeocrangon browni, Salter ms." This specimen is assigned to Crangopsis socialis by me. This is thus the highest stratigraphic record in Britain of any of the forms more characteristic of the Lower Carboniferous. The Manchester collection contains two poorly preserved unnumbered specimens apparently (data vague) from this locality; one looks tyrannophontid-like and the other seems to be a syncarid or phreatoicid isopod, but the poor preservation precludes definite identification.

51. Locality.-Coalbrookdale (SJ 6604), Shropshire.

Stratum.-Whiteflat Ironstone, Middle Coal Measures, Modiolaris Zone, Westphalian B.

Fauna.-Pygocephalus dubius*

52. Locality.-Clay Croft open works (SO 93729297), Coseley, near Dudley, Worcestershire.

Stratum. $-10 \mathrm{ft}$. Ironstone Measures, Middle Coal Measures, Lower Similis-Pulchra Zone, Westphalian B.

Fauna.-Pygocephalus cooperi

Pleurocaris annulatus

Palaeocaris retractata

Remarks. - In terms of associated stratigraphy and fossils found, this locality is most reminiscent of the Middle Pennsylvanian, Mazon Creek, Braidwood Fauna of Illinois. There are also several types of insects, an Arthropleura leg, and a strange myriapod cephalon (GSL 60200) at this locality.

53. Locality.-Bilston, (SO 9496), Staffordshire. 
Stratum.-Possibly Modiolaris Zone, Upper Westphalian A or Lower Westphalian B.

Fauna.-Pygocephalus cooperi

54. Locality.-Ridgeacre Colliery (SP 00049273), West Bromwich, Staffordshire.

Stratum.-White Ironstone Measures, Upper Modiolaris Zone, Westphalian B.

Fauna-Pygocephalus cooperi

55. Locality. -Ipstones, Staffordshire. (SK 0249).

Stratum. - “Hematite Bed," Lenisulcata Zone, Westphalian A.

Fauna.-Pygocephalus dubius

56. Locality. - Shipley Hall (SK 45004410), 11/4 miles NNW of Ilkestone, Derbyshire.

Stratum.-Clay Ironstone, top Modiolaris Zone, Middle Coal Measures, Westphalian B.

Fauna-Pygocephalus cooperi

Praeanaspides praecursor

57. Locality.-Stanton Colliery, Clay Pit South, near Burton-onTrent, Derbyshire. SK 284197.

Stratum.-Middle Coal Measures, Upper Modiolaris Zone, Westphalian B.

Fauna-Pygocephalus cooperi?

Remarks.-The one specimen from the locality (GSL 30242) is noted only from information on the label, the actual specimen was missing. No precise identification was possible.

58. Locality. - North Romesley open works (SK 468758), 1 mile SW of Balborough, near Chesterfield, Derbyshire.

Stratum. -Ironstone Band, $5 \mathrm{ft}$. above the Slough Coal, Middle Coal Measures, Lower Similis-Pulchra Zone, Westphalian B.

Fauna._Pygocephalus dubius

59. Locality.-Bondsmain Colliery (SK 420469), Temple, Normanton, Derbyshire.

Stratum.-Lower Coal Measures, low Modiolaris Zone-top Com- 
munis Zone, between the Deep Hard and the Silkeston Coals, Westphalian A.

Fauna.-Anthracophausia dunsiana (tail pieces)

Pygocephalus cooperi

Remarks.-The identification of $A$. dunsiana is based on some disarticulated telson pieces in concretions labeled Palaeomysis dunlopi in the collection at Leeds.

60. Locality.-Loscoe Colliery, (SK 42784761 or SK 424475), Heanor, Derbyshire.

Stratum.-Roof of Piper Coal, Lower Modiolaris Zone, top of Westphalian A.

Fauna.-Pygocephalus dubius

Remarks. - The locality designation in the Leeds records is ambiguous. The Loscoe pit is now called Ormonde Colliery with its shaft at the first set of co-ordinates above. There was, however, a shallow pit by that name at the second set of co-ordinates.

61. Locality.-Morton Colliery underground borehole (SK 41356040 ), depth $810 \mathrm{ft}$.; $13 \mathrm{yd}$. N $13^{\circ} \mathrm{E}$ of downcast shelf; 2,100 yd. WSW of Sitwell Grange, (8 miles west of Mansfield) Derbyshire.

Stratum. - $356 \mathrm{ft} ., 9$ in. below Kilburn Coal, Lower Coal Measures, Communis Zone, Westphalian A.

Fauna.-Anthracophausia dunsiana (tails only)

62. Locality. -Ballarat Cottage open works (SK 402760), $300 \mathrm{yd}$. W of Parkhouse Farm, 31/2 miles ESE of Dronfield, Derbyshire.

Stratum.- "Deep Hard Coal," Lower Coal Measures, Communis Zone, Westphalian A.

Fauna.-Pygocephalus dubius

63. Locality.-Trowell Colliery (SK 49323908), Nottinghamshire.

Stratum.-Kilburn Coal, Lower Coal Measures, Communis Zone, Westphalian A.

Fauna.-Anthracophausia dunsiana (tail piece)

64. Locality.-Cossal Clay Pit (SK 478432), $1 / 2$ mile NNW of Cossal, Nottinghamshire.

Stratum.-Roof of the Piper Coal, Lower Coal Measures, Lower Modiolaris Zone, Westphalian A. 


\section{Fauna.-Pygocephalus dubius}

65. Locality.-Sutton Borehole (SK 68178385), near Retford, Nottinghamshire.

Stratum.-Lower Modiolaris Zone, Lower Coal Measures.

Fauna.-Pygocephalus cooperi

Remarks. - Referred to by Edwards and Stubblefield (1948).

66. Locality.-Ollerton Colliery surface borehole (SK 65996749), depth $1252.5 \mathrm{ft}$. Nottinghamshire.

Stratum. -2 ft. Marine Band, Middle Coal Measures, Lower Similis-Pulchra Zone, Westphalian B.

Fauna.-Pygocephalus dubius

67. Locality. - Dog Lane Farm Borehole (SK 41295870), 1,460 yards E $10^{\circ} \mathrm{N}$ of Shirland Church, Derbyshire.

Stratum. $-33 \mathrm{ft}$. below Clay Cross Marine Band, Lower Coal Measures, Modiolaris Zone, Westphalian A.

Fauna.-Pygocephalus dubius

68. Locality.-Axholme borehole (SE 75980637), depth 3,160 ft., Lincolnshire, part of Lindsey.

Stratum.-Middle Coal Measures, Upper Modiolaris Zone Westphalian B.

Fauna.-Pygocephalus dubius

69. Locality.-Kirton borehole (SK 0988069130), depth 2,276 ft., Nottinghamshire.

Stratum.-Just below the second Waterloo Coal, Middle Coal Measures, Upper Modiolaris Zone, Westphalian B.

Fauna.-Pygocephalus dubius

70. Locality.-Staffordshire Coal and Iron Colliery (SJ 883433), Great Fenton, Staffordshire.

Stratum.-Middle Coal Measures, Upper Similis-Pulchra Zone, Westphalian B.

Fauna-Pygocephalus dubius

Remarks.-Referred to by Dix (1930). 
71. Locality. - "West flank of Billberry Hill in the Lickey Hills (SO 995749), southwest of Birmingham (at long. $2^{\circ} 00^{\prime} 13^{\prime \prime} \mathrm{W}$, lat. $52^{\circ} 22^{\prime}$ 37 "N)," Warwickshire.

Stratum.-Keele Beds, Westphalian D.

Fauna.-Palaeocaris retractata

Remarks.-Referred to as Stephanian by Rolfe (1961).

72. Locality.-Phoenix Brickworks at Crawcrook (NZ 135628), near Ryton-on-Tyne, Durham.

Stratum.-Hutton Coal, Middle Coal Measures, Upper Modiolaris Zone, Westphalian B.

Fauna.-Pygocephalus cooperi

91. Locality.-Near Bathing Pool, Bude, Cornwall. (SS 2106, city center).

Stratum.-Culm Measures, Westphalian A.

Fauna.-Kallidecthes eagari*

Remarks. - Some of these specimens were identified as Crangopsis huxleyi on their labels, but they are not this species based on my study of the illustrations in the literature and the stratigraphy involved.

These specimens are preserved in very unusual concretions of interest in themselves. They are almost tuff-like in quality. They appear to have been weathered and the preservation of the fossils in them is very poor. Two representative concretions were analyzed by Dr. Alex Livingston of the Royal Scottish Museum with x-ray diffraction. One concretion, which was very light and porous, was found to contain a mixture of chlorite or montmorillonite, mica and/or illite, and very fine-grained quartz. The clay minerals were poorly crystallized and it was not possible to distinguish between chlorite and montmorillonite, nor to detect any possible kaolinite. The second concretion, a denser and heavier one, was found to be very much like the first, with the exception that there might have been more mica and/or illite, or that these minerals were better crystallized. The overall background on the $\mathrm{x}$-ray of this second concretion was darker, suggesting a higher iron content. 


\section{TERMINOLOGY AND METHODS OF STUDY}

The terminology used in this monograph is of standard carcinological form and is that essentially of any standard reference, such as the Treatise on Invertebrate Paleontology Part $R$ (1969). Figure 2 is offered as a synoptic guide for terminology used in the text. The systematic scheme of higher taxa employed is derived from my own work revealing the distinctness of the Hoplocarida and Eumalacostraca (Schram, 1969b, 1973), and that of Manton (1973) and Anderson (1973) who recognize three distinct arthropod phyla. (These last two authorities independently came to the same conclusion that "arthropod" was a grade of organization which had been evolved into independently at least three times. The study of the functional morphology of locomotion by Manton and the determination of blastomere fate maps in early stages of development by Anderson. require separate origins for the major arthropod groups: uniramians, cheliceriforms, and crustaceans. If a polyphyletic approach is somehow anathema to the reader, these phyla may be considered subphyla and the following taxonomy would be little changed.)

Phylum: Crustacea Pennant, 1777 (sensu Manton, 1973)

Class: Malacostraca Latreille, 1806

Subclass: Phyllocarida Packard, 1879

Order: Hymenostraca Rolfe, 1969

Order: Archaeostraca Claus, 1888

Order: Hoplostraca Schram, 1973

Order: Leptostraca Claus, 1880

Subclass: Hoplocarida Calman, 1904

Order: Aeschronectida Schram, 1969

Order: Palaeostomatopoda Brooks, 1962

Order: Stomatopoda Latreille, 1817

Subclass: Eumalacostraca Grobben, 1892

Superorder: Eocarida Brooks, 1962

Order: Eocaridacea Brooks, 1962 

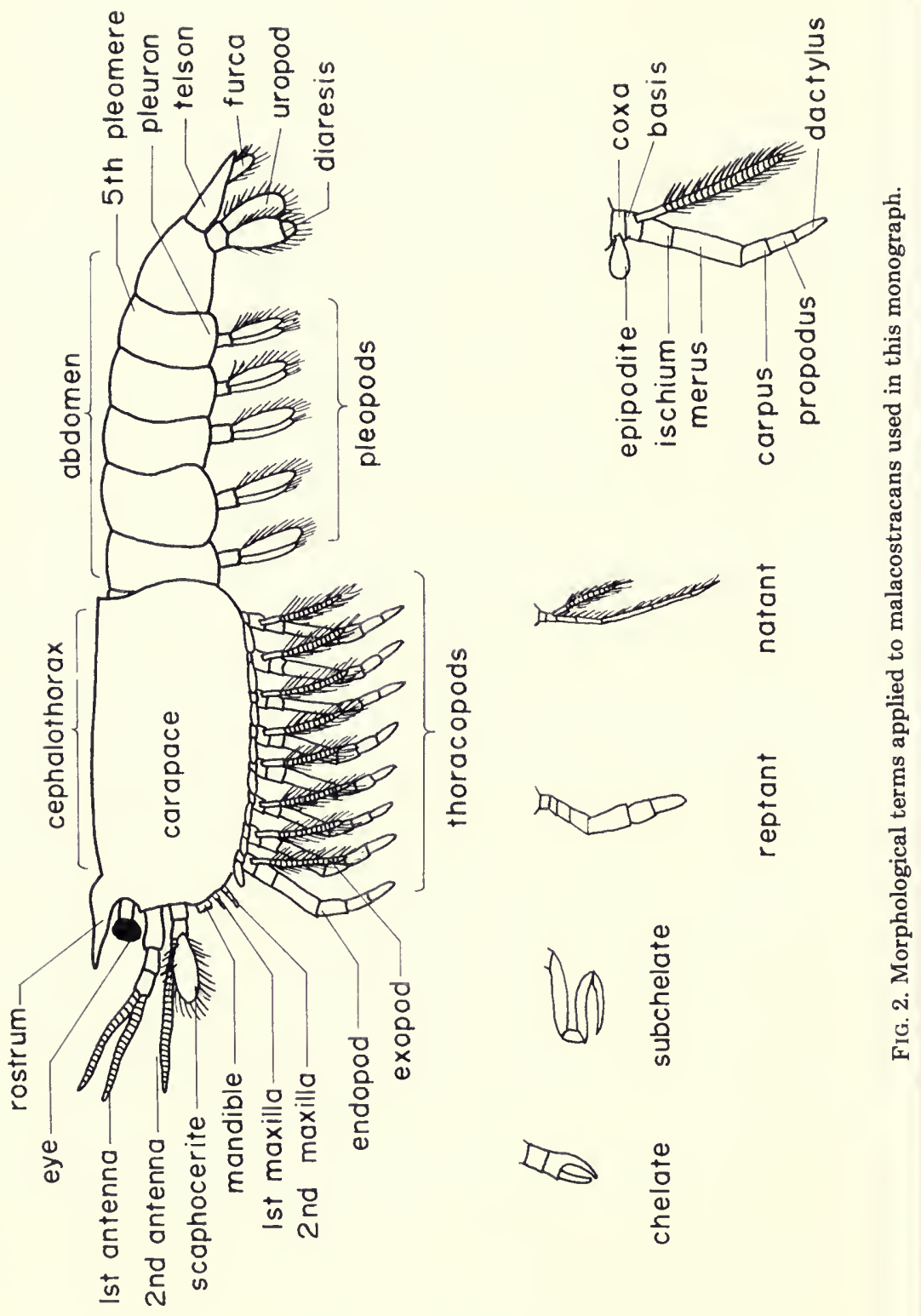
Superorder: Syncarida Packard, 1885

Order: Palaeocaridacea Brooks, 1962

Order: Bathynellacea Chappuis, 1915

Order: Anaspidacea Calman, 1904

Order: Stygocaridacea Noodt, 1962

Superorder: Pancarida Monod, 1927

Order: Thermosbaenaecea Monod, 1927

Superorder: Peracarida Calman, 1904

Order: Mysidacea Boas, 1883

Order: Cumacea Kroyer, 1846

Order: Spelaeogriphacea Gordon, 1957

Order: Tanaidacea Dana, 1853

Order: Isopoda Latrielle, 1817

Order: Amphipoda Latrielle, 1816

Superorder: Eucarida Calman, 1904

Order: Euphausiacea Dana, 1852

Order: Decapoda Latrielle, 1803

Order: Amphionidea Williamson, 1973

I have attempted to examine as much material in addition to the types as I could. My initial morphologic observations were made with as little reference to past work as possible and only subsequently was reconciliation with the literature attempted. In the cases of descriptions of Calman (1911-1933) and Huxley (1857) little change was needed, while in instances of some of Peach's descriptions some problems can never be resolved for reasons given above.

Some species are based on only one, or a few, specimens which do not allow adequate diagnosis, e.g., "Perimecturus" pattoni Peach, 1908 has one specimen and on the basis of it alone I am reluctant to place it in a higher category. Such material I have had to leave incertae sedis. Species for which all type material is missing (probably permanently) are simply placed in the most probable taxon that can be determined through the literature.

Finally, in this paper, I have dealt with only one phyllocarid in great detail, Sairocaris elongata (Peach), 1882 because it is characteristically associated with Carboniferous hoplocarid and eumalacostracan faunas. Jones and Woodward (1888-1899) did not deal with S. elongata, but do cover other British Paleozoic phyllocarids.

Measurements were taken with a caliper, lengths are along the 
dorsal midline unless otherwise stated. I do not believe the preservation of these fossils warrants any more than simple statistical treatments.

\section{ABBREVIATIONS}

The abbreviations for the names of institutions are my own and are given below. Institutions are listed here in order of their importance, usefulness, and accessibility for purposes of this study:

GSE Institute of Geological Sciences, Edinburgh

GSL Institute of Geological Sciences, Leeds

R Royal Scottish Museum, Edinburgh

L University of Manchester Museum

A Hunterian Museum, University of Glasgow

E Sedgwick Museum, Cambridge

K Kelvingrove Museum and Art Gallery, Glasgow

BU Birmingham University Museum

P Field Museum of Natural History, Chicago, Illinois

OE Oxford University Museum

GI Grant Institute, University of Edinburgh

D Dick Institute, Kilmarnock

NMW National Museum of Wales, Cardiff

In, I British Museum (Natural History)

Synonymy list annotations of Richter (1948), as outlined by S. C. Matthews (1973), are used throughout. 


\section{BIOSTRATIGRAPHY AND ZOOGEOGRAPHY}

The stratigraphic positions of the localities in the previous section are given in Figure 1. An effort has been made, with the assistance of the Institute of Geological Sciences, to incorporate some of the latest correlation information, modifying the chart of Francis in Craig (1965, p. 344).

It can be seen that these malacostracans form two distinct faunas. The Viséan fauna is a very diverse, near-shore, marine assemblage with a predominance of hoplocarid and pygocephalomorph types. There are other elements as well, including the distinct phyllocarids, Sairocaris elongata, a tanaidacean, various "eocarids," and the problematic Joanella elegans. The Viséan fauna is best represented in the Glencartholm assemblage. With the possible exception of $\mathrm{An}$ thracophausia dunsiana, the components of the Viséan fauna are separated from the Westphalian fauna by a distinct paucity of forms in the Namurian. Both the Viséan and Westphalian crustacean faunas are located in some proximity to a shore line.

This Namurian hiatus is unfortunate since there is a definite change in the faunas from what is seen in the Viséan to what occurs in the Coal Measures. The Coal Measure fauna is a more brackishfreshwater type, with mainly pygocephalomorphs and syncarids. Details of the transition from one fauna to the other would have been of interest in terms of perhaps affording some possible insight into the eventual decline of the Paleozoic eumalacostracans.

The Coal Measure (Westphalian) crustaceans are very similar to the Mazon Creek, Braidwood crustaceans of Illinois. There are different genera and species but the orders and families are the same. There is an almost point by point correspondence between the two assemblages (see table 1). This pygocephalomorph-syncarid grouping is apparently characteristic of the brackish or freshwater, nearshore facies of the Upper Carboniferous-Pennsylvanian.

The Glencartholm fauna of the Viséan is quite distinctive from the Coal Measure fauna and is comparable to the Middle Pennsylva- 
TABLE 1. Comparison between two Upper Carboniferous brackish-freshwater eumalacostracan assemblages. Corresponding species are on the same line, lack of correspondent is indicated with a dash.

\section{British \\ Coal Measure \\ Fauna \\ (Westphalian)}

Pygocephalomorpha Pygocephalus cooperi

Pleurocaris annulatus

Syncarida
Palaeocaris retractata

Praeanaspides praecursor
Illinois

Braidwood

Fauna

(Middle Pennsylvanian)

Anthracaris gracilis

Acanthotelson stimpsoni

Palaeocaris typus

nian Essex fauna of Illinois, but the similarities between the two faunas do not form a point for point correspondence (see table 2). There is perhaps an ancestor-descendant relationship between Glencartholm and Essex, but not an exact correspondence of components. When comparing the Essex crustaceans to the Glencartholm, one sees a definite decline in the importance of the hoplosiracans. Sairocaris constitutes a large percentage of the assemblage at Glencartholm whereas any phyllocarids are rare in the Essex fauna. Pygocephalomorphs, palaeostomatopods, and possibly the aeschronectids decline by Essex time. The "eocarids" are more diverse in Essex time than in Glencartholm. The advanced peracarids are more evident in the Essex fauna with both tanaids and isopods, but they still do not constitute a major proportion of the Pennsylvanian crustaceans. The stomatopods appear by Essex time, though there may be a precursor of these in the late Viséan in the guise of "Perimecturus" pattoni. While there is a continuity between Glencartholm and Essex, there are some differences between the two.

The Culm Measure Kallidecthes eagari is intriguing. It stands apart geographically and taxonomically from the typical Coal Measure fauna. The Culm Measures represent a more deltaic facies than the coastal swamps of the typical Coal Measures. $K$. eagari corresponds to the North American Essex aeschronectid, Kallidecthes richardsoni. It is interesting to speculate whether $K$. eagari represents part of a more extensive, but as yet undiscovered, British equivalent of the Essex Fauna of Illinois.

There are also some noteworthy biogeographic patterns in the Viséan faunas of Scotland and Northumberland. There are two con- 
TABLE 2. Comparison between the Crustacea of the Visean Glencartholm Fauna and the Pennsylvanian (Westphalian C) Essex Fauna. Corresponding species are matched. Lack of a correspondence is indicated by a dash.

\section{British \\ Glencartholm Fauna \\ (Viséan)}

Phyllocarida

Sairocaris elongata

$-$

Palaeostomatopoda

Stomatopoda

Aeschronectida

Eocaridacea

Pygocephalomorpha

Tanaidacea

Isopoda
Perimecturus parki

Bairdops elegans

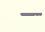

Crangopsis eskdalensis

Belotelson traquairi Anthracophausia dunsiana

-

$-$

Pseudogalathea

Pseudotealliocaris

etheridgei

Anthracocaris scotica

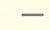

Tyrannophontes theridion

Kallidecthes richardsoni

Belotelson magister

Anthracophausia ingelsorum

Peachocaris strongi

Essoidia epiceron

macconochiei

Mamayocaris jaskoskii

Cryptocaris hootchi

Hesslerella shermani

temporaneous species of Crangopsis which occur in different areas: C. socialis is found north of the Southern Uplands in the Midland Valley Trough, and C. eskdalensis in the Northumbrian Trough. Waterstonella grantonensis is also found only in the Midland Valley Trough and not in Northumbria (fig. 3). Indeed, the Glencartholm Fauna, the most diversified Viséan assemblage, is characterized by elements found largely only in the Northumbrian Trough. Few forms occur on both sides of the Southern Uplands Massif. Pseudogalathea macconochiei and Tealliocaris woodwardi are found on both sides of the uplands. T. woodwardi is peculiar in that it frequently occurs alone, without any associated crustaceans and the $T$. 


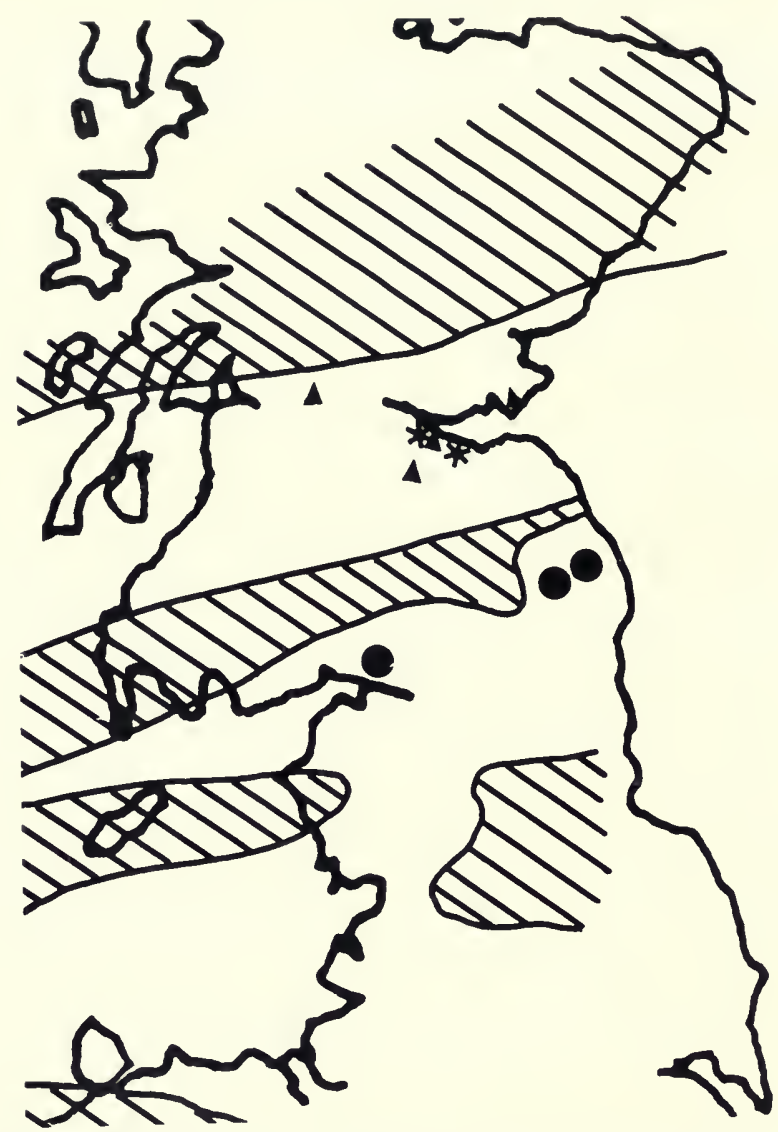

FIG. 3. Geographic distribution of some Scottish Viséan species of malacostracans in relation to paleogeographic land masses. $\Delta$ Crangopsis socialis, $\bullet$ C. eskdalensis, $\star$ Waterstonella grantonensis. Map modified from George (1957). Land masses shaded.

woodwardi of the Midland Valley may be stratigraphically somewhat higher than those of Northumbria.

The distinctness of Northumbrian and Midland Valley crustaceans seems to have disappeared with the approach of Namurian time. The Millstone Grit of Lancashire contains $C$. socialis. Red Cleuch Burn, Limestone Coal Group of Stirlingshire, at the Viséan-Namurian boundary, has Crangopsis sp. associated with some apparent Anthracophausia dunsiana tails. These two localities stratigraphically occur at a time when the Southern Uplands Massif was submerging and disappearing as a potential paleozoogeographic barrier. 

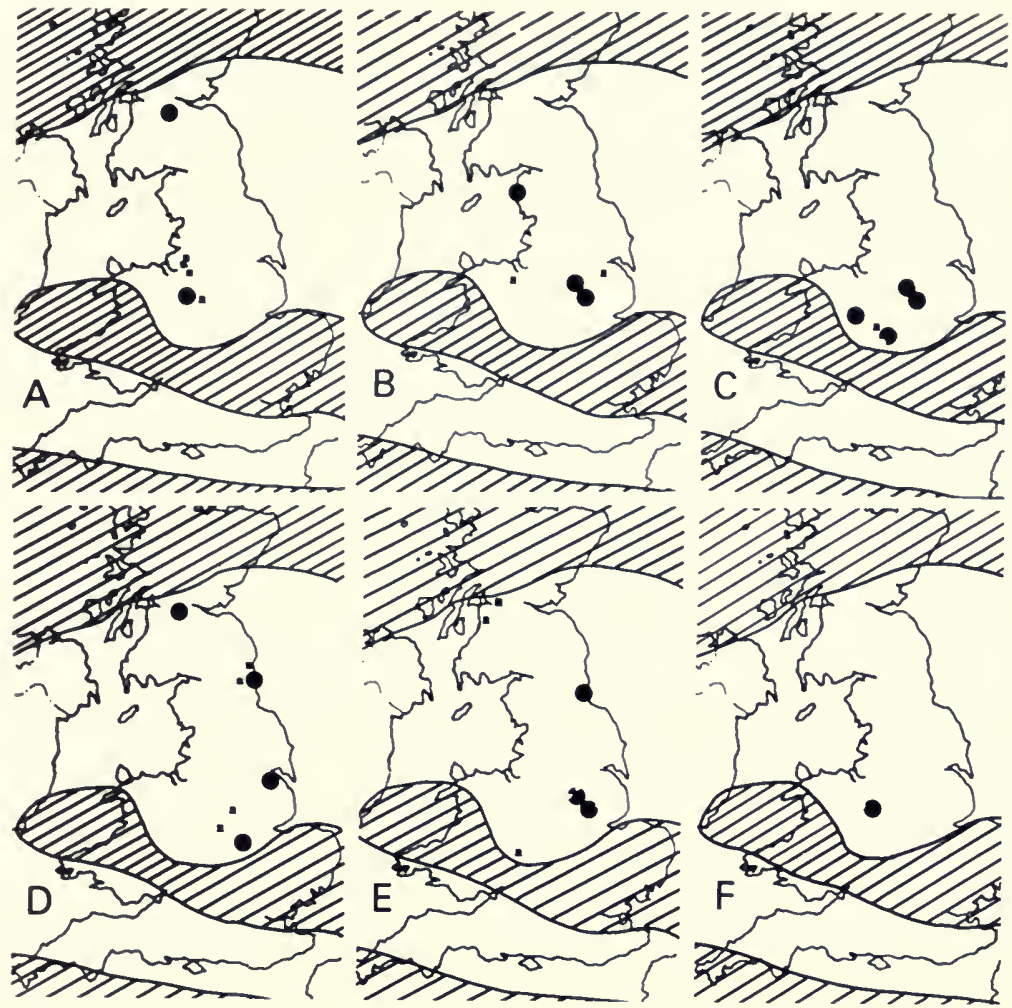

FIG. 4. Geographic distribution of the Westphalian species of Pygocephalus. $P$. cooperi, - P. dubius. A, Lenisulcata and Communis Zones; B, Lower Modiolaris Zone; C, Middle Modiolaris Zone; D, Upper Modiolaris Zone; E, Lower SimilisPulchra Zone; F, Upper Similis-Pulchra Zone. Land masses shaded.

One can only speculate on the existence of two contemporaneous species of Pygocephalus in the Coal Measure Fauna: P. cooperi and $P$. dubius. Some differences do exist between these two species in their occurrence. Stratigraphically, the ranges of these two species are somewhat different. $P$. cooperi seems to have its earliest occurrence slightly lower than $P$. dubius, and $P$. dubius apparently persisted longer. When examining the individual geographic occurrences of both species (fig. 4) through time, some patterns emerge. In the Communis and Lenisulcata Zones, $P$. cooperi is moderately more widespread and certainly more common than $P$. dubius, the latter being more common in the northern part of the Penine Delta region. $P$. dubius seems to spread south through the Modiolaris Zone and becomes more common than $P$. cooperi. In the Similis-Pul- 
chra Zone $P$. dubius is the last to survive, $P$. cooperi being known from only a few localities. In general, $P$. cooperi seems to be more common in the lower Westphalian beds and is largely replaced by $P$. dubius in the upper part of the Westphalian.

In addition to this general pattern noted above, $P$. dubius does not occur with any other crustaceans, while $P$. cooperi is frequently found in association with the syncarids Pleurocaris annulatus, Palaeocaris retractata, and/or Praeanaspides praecursor. The shifting dominance of $P$. dubius through Westphalian may reflect some environmental change to increasing freshwater conditions. In this regard it is significant to note nine of the $15 P$. cooperi localities are sites at which the animals are preserved in concretions of iron carbonate. None of the $P$. dubius specimens are in concretions but are typically preserved in black shales. Different modes of fossilization may reflect different environmental regimes of the living animals. The gray shale and concretion preservations of $P$. cooperi along with associated faunas may indicate a river or deltaic facies preference for this species. The black shale and its associated clam fauna may point to a lagoonal or back-water habitat for $P$. dubius. Thus shifting geographic and stratigraphic predominance of these species may also reflect shifts in ecotomes in the Penine Delta Swamp region through Westphalian time. 


\section{SYSTEMATIC DESCRIPTIONS}

\section{Subclass: Phyllocarida Packard, 1879}

Remarks.-Jones and Woodward (1888-1899) monographed the British Phyllocarida. There has been no comprehensive treatment of these since that time and Rolfe (personal communication) points out a need of revision. It was not the purpose of this present study to deal so much with the phyllocarids as it was to concentrate on Hoplocarida and Eumalacostraca. Jones and Woodward did not, however, consider the genus Sairocaris Rolfe, 1963 (pro Acanthocaris Peach, 1883). This was an oversight since Peach placed his fossils in the Phyllocarida but treated them in papers dealing with Eumalacostraca. Because of this oversight and the important association of Sairocaris with other malacostracans in the British Carboniferous faunas, I consider this genus in detail below. The only other Carboniferous phyllocarid in Britain is Dithyrocaris, according to Jones and Woodward.

Order: Archaeostraca Claus, 1888

Family: Rhinocarididae Hall and Clarke, 1888

Dithyrocaris Scouler, 1843. Figure 5.

Remarks.-Dithyrocaris is found in some British Lower Carboniferous localities and such has been noted in the localities section of this work. The genus is badly in need of revision (Rolfe, personal communication), however, and I have not seen fit to undertake such a major effort here. The problem, common in phyllocarid systematics, is that many species are based on parts of animals, e.g., carapaces, parts of carapaces, telsons with or without furca, and portions of abdomens. As a result it is difficult to compare species. Dithyrocaris testudinea (fig. 5) is one of the few whole-animal phyllocarid fossils known from the British Carboniferous.

Order: Hoplostraca Schram, 1973

Family: Sairocarididae Schram, 1973 
FIG. 5. Dithyrocaris testudinea (Scouler), 1835, holotype in the Kelvin Grove Museum, Glasgow.

Photograph compliments of Dr. W. D. I. Rolfe, Hunterian Museum, Glasgow.

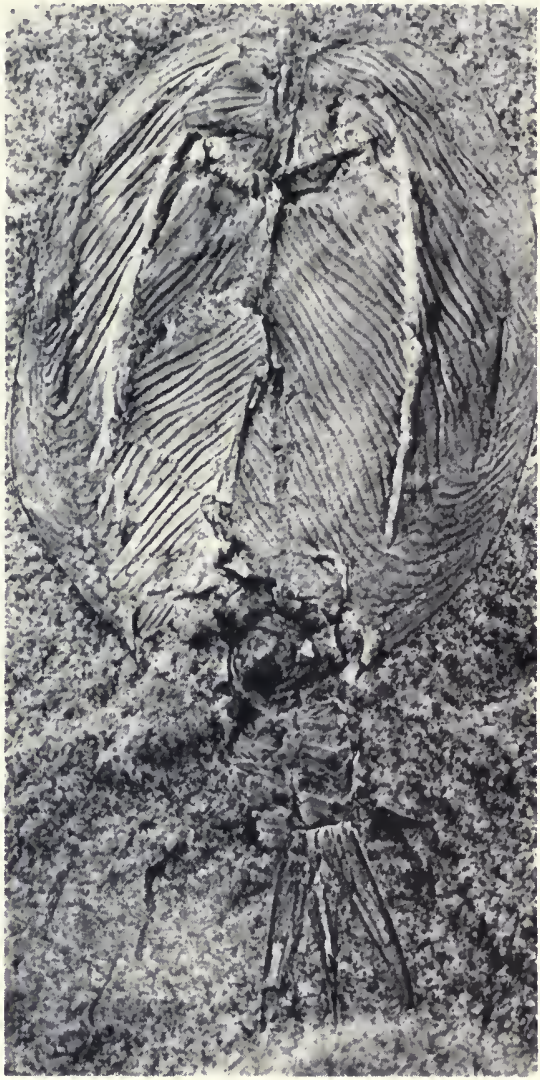

Sairocaris Rolfe, 1963

(pro Acanthocaris Peach, 1883, non Sim, 1872)

Type species. - Ceratiocaris elongatus Peach, 1882; Glencartholm; Calciferous Sandstone Measures.

Diagnosis. - Carapace subtriangular. Posterior three to four thoracomeres not covered by carapace. Fifth pleomere with a notch on the antero-ventral edge of pleuron. Individual pleomeres increase in length from anterior to posterior. Caudal furca tiny.

Sairocaris elongata (Peach), 1882. Figures 6-8, Table 3.

v*. 1882 Ceratiocaris scorpioides Peach, p. 73, pl. 7, fig. 1-1f.

v.* 1882 Ceratiocaris elongatus Peach, p. 74, pl. 7, fig. 2-2f.

v*.? 1883 Acanthocaris attenuatus Peach, p. 512, pl. 28, fig. 1-1c. 1883 Acanthocaris elongatus (Peach). Peach, p. 512. 1883 Acanthocaris scorpioides (Peach), Peach, pl. 28, fig. 2. 

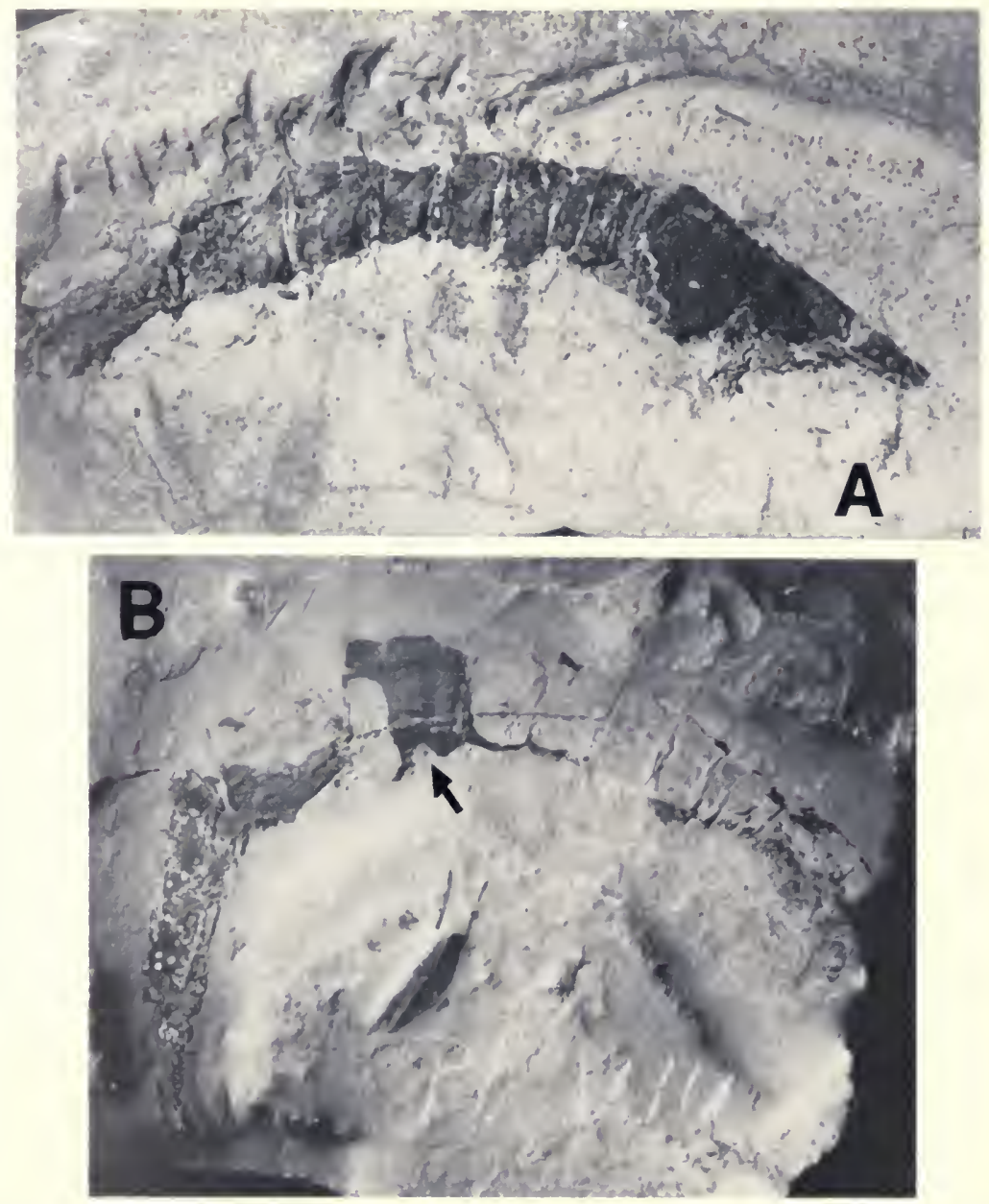

FIG. 6. Sairocaris elongata (Peach), 1882. A, GSE 5795, lectotype, with cephalon and anterior abdomen, $1.4 \times$. B, GSE 5797, arrow pointing to notch on fifth pleomere, $1.5 \times$.

1903 Acanthocaris elongatus (Peach). Peach and Horne, p. 846. 1903 Acanthocaris attenuatus Peach. Peach and Horne, p. 846. 1903 Acanthocaris scorpioides (Peach). Peach and Horne, p. 846. 1963 Sairocaris elongata (Peach). Rolfe, p. 486. 1969 Sairocaris attenuata (Peach). Rolfe, p. R327. 1969 Sairocaris elongata (Peach). Rolfe, p. R328, fig. 152-154. 1973 Sairocaris elongata (Peach). Schram, p. 80, figs. 6, 8.

Lectotype.-GSE 5795, fig. 6d; River Esk, Glencartholm, 11/2 miles below Langholm, Dumfriesshire; Glencartholm Volcanic 
FIG. 7. Sairocaris elongata (Peach), 1882. GSE 5796, seventh pleomere and telson, $1.1 \times$.

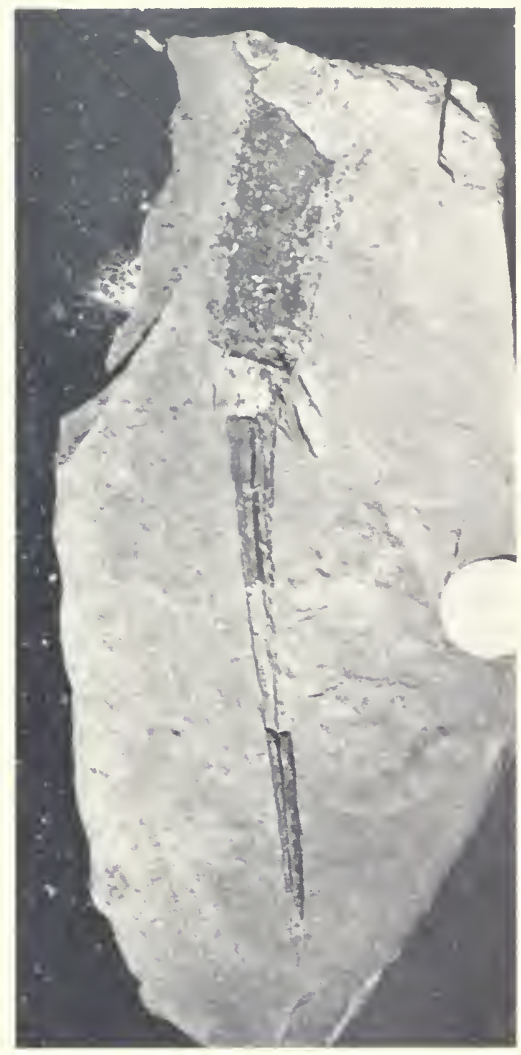

Beds, Calciferous Sandstone Measures.

Diagnosis.-Carapace covering all but last three thoracomeres. Anterior pleomeres all of same dapth. Notch on fifth pleomere ovoid. Telson to seventh pleomere ratio approximately $3: 1$ to $2: 1$.

Description. - The carapace is subtriangular in outline and is attached to only the most anterior segments of the cephalothorax. The three most posterior thoracomeres are decidedly longer than those thoracic segments immediately anterior to them (GSE 5797). The exoskeleton on all segments seems to be smooth (GSE 5798). Those few specimens that have a lateral ridge appear to have been distorted in preservation. The fifth pleomere has a distinct notch on the anterior ventral edge of the pleuron. This notch varies from being semi-circular in outline (GSE 5797, fig. $6 \mathrm{~b}$ ) to semi-elliptical (GSE 5800). The telson is extremely long, at least twice the length of the last abdominal segment. The telson is decorated along a 
lateral groove with a line of papillations (GSE 5796, fig. 7). GSE 5795 (fig. 6a) preserves what seem to be large thin, flap-like pleopods on abdominal segments 2 and 3.

Remarks. - The species of Peach (1882), A. elongata and A. scorpioides, form a coherent taxon. A. attenuatus is represented by two very poorly preserved specimens (GSE 5793 , GSE 5794) which are "film-like" outlines of what might be an abdomen and telson but are of such poor quality as to be almost unworthy of the term fossil. Peach never indicated a type species for his genus Acanthocaris but indicated that all three species were related to each other and distinct from Ceratiocaris. Van Straelen and Schmitz (1934) in the Fossilium Catalogus list $A$. attenuatus as the type species of Acanthocaris, but incorrectly report its date of description (1883) as that of $A$. scorpioides and $A$. elongata (1882). Rolfe (1963) dealt with the required genus name change and used $S$. elongata as the species. Schram (1973) followed Rolfe's lead. Therefore, as first revisor I have designated Ceratiocaris elongata Peach, 1882 the type species of Sairocaris Rolfe, 1963, since the status of A. attenuatus is questionable and $C$. scorpioides has virtually dropped out of use since its description.

The possible phyletic significance of the Hoplostraca has been discussed by Schram (1973). The hoploid-like nature of these animals is further heightened by study of GSE 5797 in which the anterior thoracomeres are much shorter and reduced over the three posterior most thoracomeres, an arrangement reminiscent of that seen in stomatopods. In the mantis shrimp the five anterior thoracomeres are reduced in size and partially fused with each other while the posterior three thoracomeres are large and are structurally associated with the abdominal segments. Such striking segment similar-

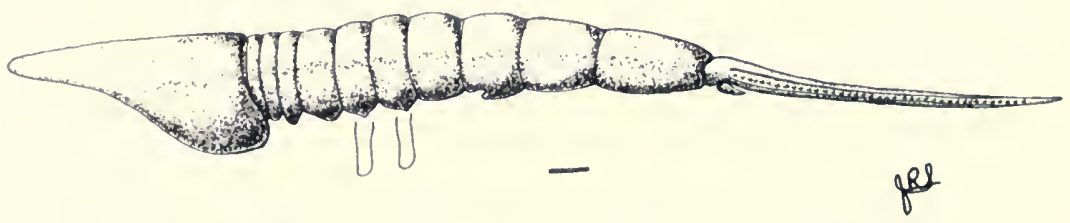

FIG. 8. Sairocaris elongata (Peach), 1882, reconstruction, scale $5 \mathrm{~mm}$.

ity might well indicate similarity of habit, i.e., due to convergence rather than actual direct relationship.

Measurements of some of the better $S$. elongata specimens are given in Table 3, a reconstruction in Figure 8. 


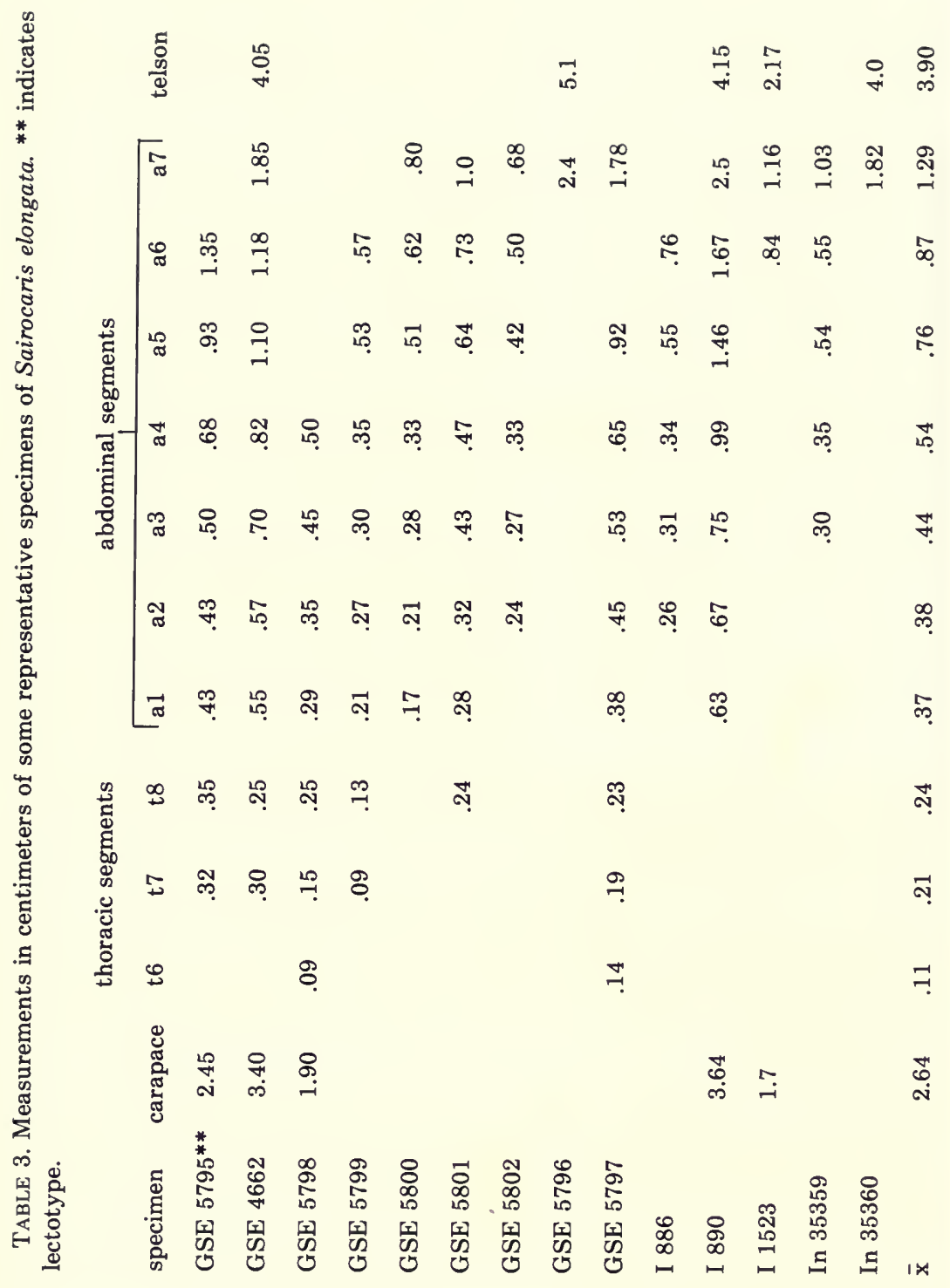


Subclass: Hoplocarida Calman, 1904

Order: Aeschronectida Schram, 1969b

Family: Aratidecthidae nov.

Type genus.-Aratidecthes Schram, 1969b; Garrard Quarry, Indiana; Logan Quarry Shale, Middle Pennsylvanian (Westphalian C).

Diagnosis. - No rostrum. Antennae well developed. Carapace rectangular to trapezoidal in lateral outline. Second maxillae small and unspecialized. Pleopods unspecialized.

Crangopsis Salter, 1863a

(pro Palaeocrangon Salter, 1861b, non vonSchauroth, 1854)

Type species.-Uronectes socialis Salter, 1861a. Ardross, Fifeshire; Calciferous Sandstone Measures.

Diagnosis.-Carapace subtrapezoidal. Antennal peduncles modderately large and long. Abdomen $2 \frac{1}{2}$ times the length of the cephalothorax. Abdominal pleura well developed. Sixth pleomere especially elongate. Pleuron of second pleomere extends markedly anteriad as well as posteriad.

Remarks.-The affinity of the genus Crangopsis to the North American aeschronectids is quite obvious. Although neither species of Crangopsis is as generally well preserved as either Kallidecthes richardsoni or Aratidecthes johnsoni, the affinity of Crangopsis seems to lie with Aratidecthes. Crangopsis and Aratidecthes both have a prominent development of the antennal peduncles, lack a rostrum, and seem to have no unusual specializations of the second maxillae such as is found in Kallidecthes. Comparison of the thoracopods is difficult. $C$. socialis may have had a reptant development like $A$. johnsoni, while $C$. eskdalensis was a smaller animal, is typically found together in large aggregations or "schools," and may have had more delicate, nektonic thoracopods (and thus subject to poorer preservation).

Aratidecthes differs from Crangopsis in having a rectangular carapace, very long antennules, the second, fifth, and sixth pleomeres elongate, and no marked anterior and posterior inflation of the pleuron of the second abdominal segment.

The two species of Crangopsis are readily distinguishable from each other. $C$. socialis is somewhat the larger of the two, $C$. socialis has a more postero-ventral development of the carapace. $C$. socialis 


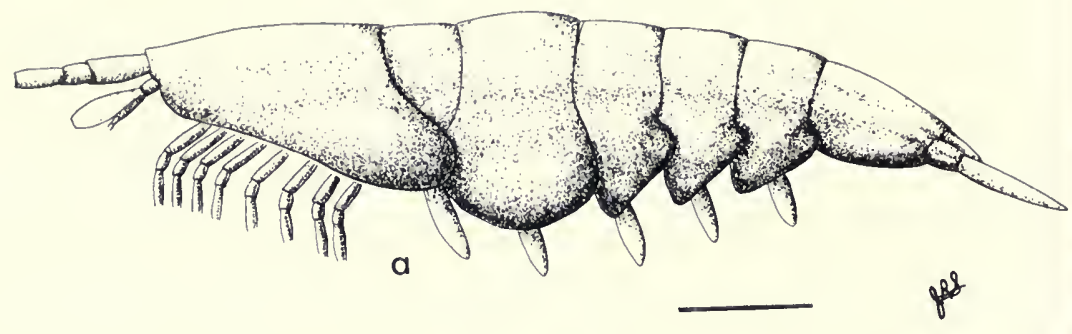

b

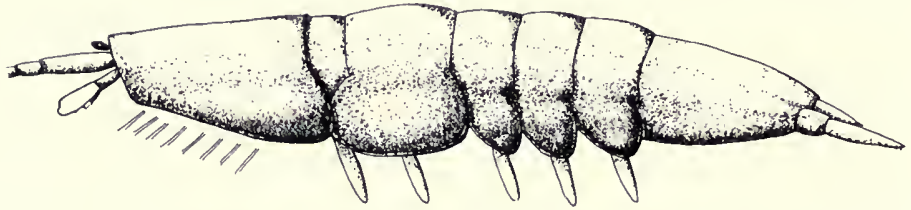

FIG. 9. Reconstructions of: A, Crangopsis socialis; B, C. eskdalensis, scale $5 \mathrm{~mm}$.

has a long first pleomere while that of $C$. eskdalensis is short. $C$. socialis has a broadly rounded, equally extended second abdominal pleural lappet, while that of $C$. eskdalensis is more extended anteriorly and flattened ventrally. The pleura of the posterior pleomeres on $C$. socialis are attenuated at the postero-ventral corner.

There is also a difference in the Viséan paleogeographic distribution of these two species. $C$. socialis is collected from localities in the Midland Valley of Scotland, while C. eskdalensis is generally noted from sites in the Northumbrian basin, i.e., south of the Southern Uplands. Measurements for $C$. socialis and C. eskdalensis are given in Tables 4 and 5 respectively, and reconstructions in Figure 9.

Crangopsis socialis (Salter), 1861. Figures 9, 10. Table 4.

v*. 1861a Uronectes socialis Salter, p. 394, fig. 2.

1861b Palaeocrangon socialis (Salter). Salter, p. 533, fig. 8a-8c.

v. $1861 \mathrm{~b}$ Palaeocrangon sp. Salter, p. 533.

? 1862 Pygocephalus sp. Huxley, p. 420, fig. 1.

$1863 a$ Crangopsis socialis (Salter). Salter, p. 80.

? 1867 Pygocephalus huxleyi Woodward, p. 243, figs. 1, 2.

v. 1908 Crangopsis socialis (Salter). Peach, p. 69, figs. 7-11.

? 1908 Crangopsis huxleyi (Woodward). Peach, p. 82, pl. 11, fig. 8.

1911 Crangopsis socialis (Salter). Woodward, p. 363.

? 1911 Crangopsis huxleyi (Woodward). Woodward, p. 363.

1969 Crangopsis socialis (Salter). Brooks, p. R343, fig. 155A.

1969 a Crangopsis socialis (Salter). Schram, p. 215, table 1.

1969a Crangopsis huxleyi (Woodward). Schram, p. 216, table 1. 
Holotype.-GSL 87432 (fig. 10); Ardross Shore, Fifeshire; Lower Ardross Limestone, Calciferous Sandstone Measures.

Diagnosis. -Carapace elongated postero-ventrally. First pleomere as long as the other pleomeres. Second abdominal pleuron broadly rounded. Posterior pleomere pleura attenuated on postero-ventral corners.

Description. - The carapace is subtrapezoidal in outline, but has a marked posterior and ventral development ( $R$ 1969.15.1, $R$ 1969.15.2). There is apparently no rostrum. The first antennal peduncle consists of a proximal large, long segment, followed by a second shorter segment, and a third distalmost segment almost equal in size to the second. Both the second and third segments together are about as long as the first. The second antennal peduncles are also large, but are laterally and ventrally directed. The relative sizes of the second antennal peduncular segments are obscure, but $\mathrm{R}$ 1951.1.5111 preserves a large scaphocerite.

The thoracopods ( $\mathrm{R}$ 1969.15.2) are strongly developed and appear to be almost reptant in nature. The posterior margins of the thoracopod segments bear ornamentation which may be the bases of setae. The number and relative sizes of the basal segments of the thoracopods are obscure, but the first segment beyond the base is very long

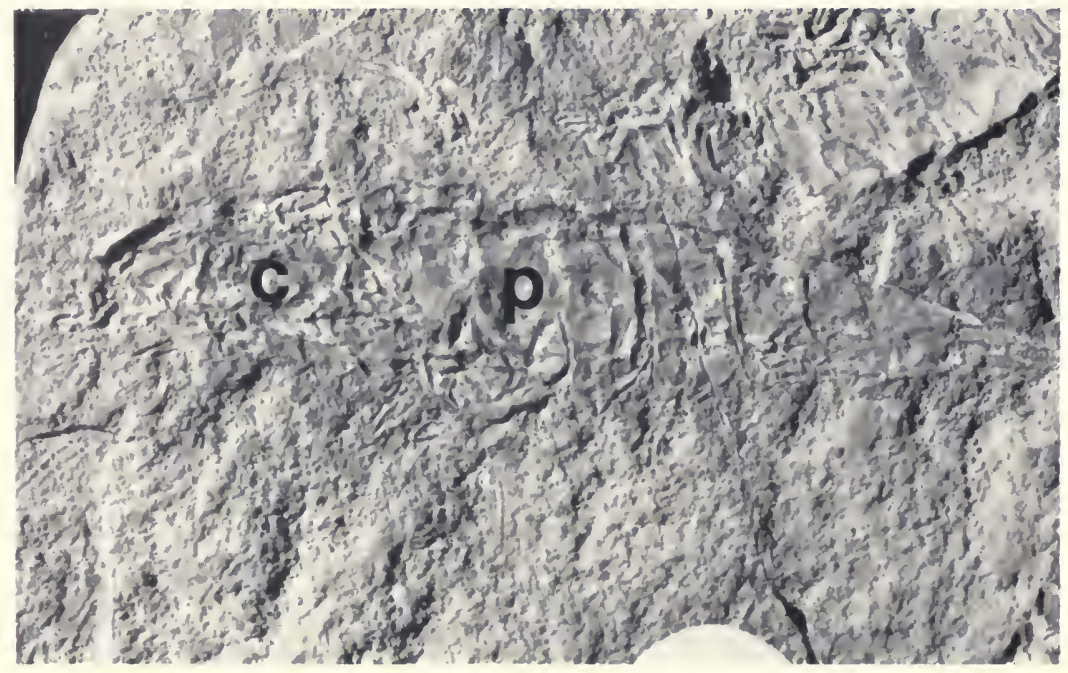

Fig. 10. Crangopsis socialis (Salter), 1861. GSL 87432, holotype, with carapace (c) and second pleomere (p), $2.9 \times$. 
and is followed by a much shorter segment. Leg segments distal to these are not known.

The abdomen is approximately $2 \frac{1}{2}$ times the length of the cephalothorax. The first pleomere is as long as the second but its pleuron is completely obscured by the posterior development of the carapace and the anterior inflation of the second pleomere pleuron. The second abdominal pleuron is as equally developed anteriorly as posteriorly and is rounded and extended ventrally. The pleura of the remaining abdominal segments are attenuated along the posterior ventral corner and greatly overlap the next segment posteriad. The sixth pleomere is elongate and narrow. GSE 4666 and GSE 4669 seem to indicate a short spade-like telson and elongate blade-like uropods. Little can be discerned of the pleopods except that they were rather thin and flattened ( $R$ 1969.15.1).

Remarks. - A search of all known collections failed to turn up the type specimen of Crangopsis huxleyi (Woodward), 1867. This species was described from a specimen in the private collection of a Rev. Mr. Fraser, M.A. It was collected ". . f from one of the coal and ironstone mines in the Strath of Clyde, about two miles from Paisley, in dark shale." "This dark shale . . . is about 19 fathoms below the surface. The ironstone-clay-band lies about 7 fathoms above it; and 36 fathoms beneath it occurs what is known as the Hurlet or Nitshill Coal."

The staff at I.G.S., Edinburgh, place this stratigraphically just above the Top Hosie Limestone, just into the Limestone Coal Group. Although there is little chance of deciding where this locality was, let alone re-collecting it, it is stratigraphically equivalent to my locality number 16 (see locality section) which does have some Crangopsis cf. socialis. It is likely therefore, in light of this, and from a study of the original description and illustrations, that this was probably a specimen of Crangopsis socialis.

Crangopsis eskdalensis (Peach), 1882. Figures 9b, 11. Table 5.

v*. 1882 Palaeocrangon eskdalensis Peach, p. 84, pl. 8, fig. 9-9i.

1903 Palaeocrangon eskdalensis Peach and Horne, p. 846.

v. 1908 Crangopsis eskdalensis (Peach). Peach, p. 80, pl. 11, figs. 1-7.

1911 Crangopsis eskdalensis (Peach). Woodward, p. 363.

1969 Crangopsis eskdalensis (Peach). Brooks, p. 343, fig. 158, 6.

1969a Crangopsis eskdalensis (Peach). Schram, p. 215, table 1.

Lectotype (here designated).-GSE 5007 (fig. 11); Glencartholm, 
TABLE 4. Measurements of some representative specimens of Crangopsis socialis in centimeters. (Some specimens have more than one individual on them.) *indicates holotype.

\begin{tabular}{|c|c|c|c|c|c|c|c|c|}
\hline \multirow{2}{*}{ specimen } & \multirow{2}{*}{ carapace } & \multirow{2}{*}{$\begin{array}{c}\text { total } \\
\text { abdomen }\end{array}$} & \multicolumn{6}{|c|}{ abdominal segments } \\
\hline & & & 89 & ? & 83 & 84 & a5 & a6 \\
\hline GSL $87342^{*}$ & .85 & 2.03 & & .43 & & .34 & .28 & .62 \\
\hline GSE 4666 & .98 & 2.30 & & & & & & \\
\hline GSE 4667 & .97 & & .37 & .50 & & & & \\
\hline GSE 4667 & .74 & 1.96 & & & & & & \\
\hline GSE 4667 & & 1.90 & & & & & & \\
\hline GSE 4669 & & 2.15 & & & & & & \\
\hline GSE 8735 & .90 & 2.35 & & & & & & \\
\hline R 1957.1.5111 & .97 & 2.07 & & & & & & \\
\hline R 1969.15.1 & 1.0 & 2.42 & .28 & .53 & .37 & .35 & .34 & .54 \\
\hline R1969.15.2 & .80 & & & & & & & \\
\hline In 14927 & .80 & 2.02 & & & & & & \\
\hline In 14927 & .74 & 2.26 & & & & & & \\
\hline$\overline{\mathbf{x}}$ & .88 & 2.15 & & & & & & \\
\hline
\end{tabular}

River Esk, 11/2 miles below Langholm, Dumfriesshire; Glencartholm Volcanic Beds, Calciferous Sandstone Measures.

Diagnosis.-Carapace rounded on postero-ventral corner. First pleomere short. Second abdominal pleuron flattened ventrally. Posterior pleomere pleura rounded on postero-ventral corners.

Description. - The carapace is subtrapezoidal, almost rectangular, with apparently no rostrum. A very slight doublure can be seen on the margins of the carapace (GSE 5845). The antennal peduncles are quite large. The first antennae seem to have a long proximal-most segment, followed by a second segment about one-third the length of the first (GSE 5007, fig. 11a), while the third segment is not pre- 


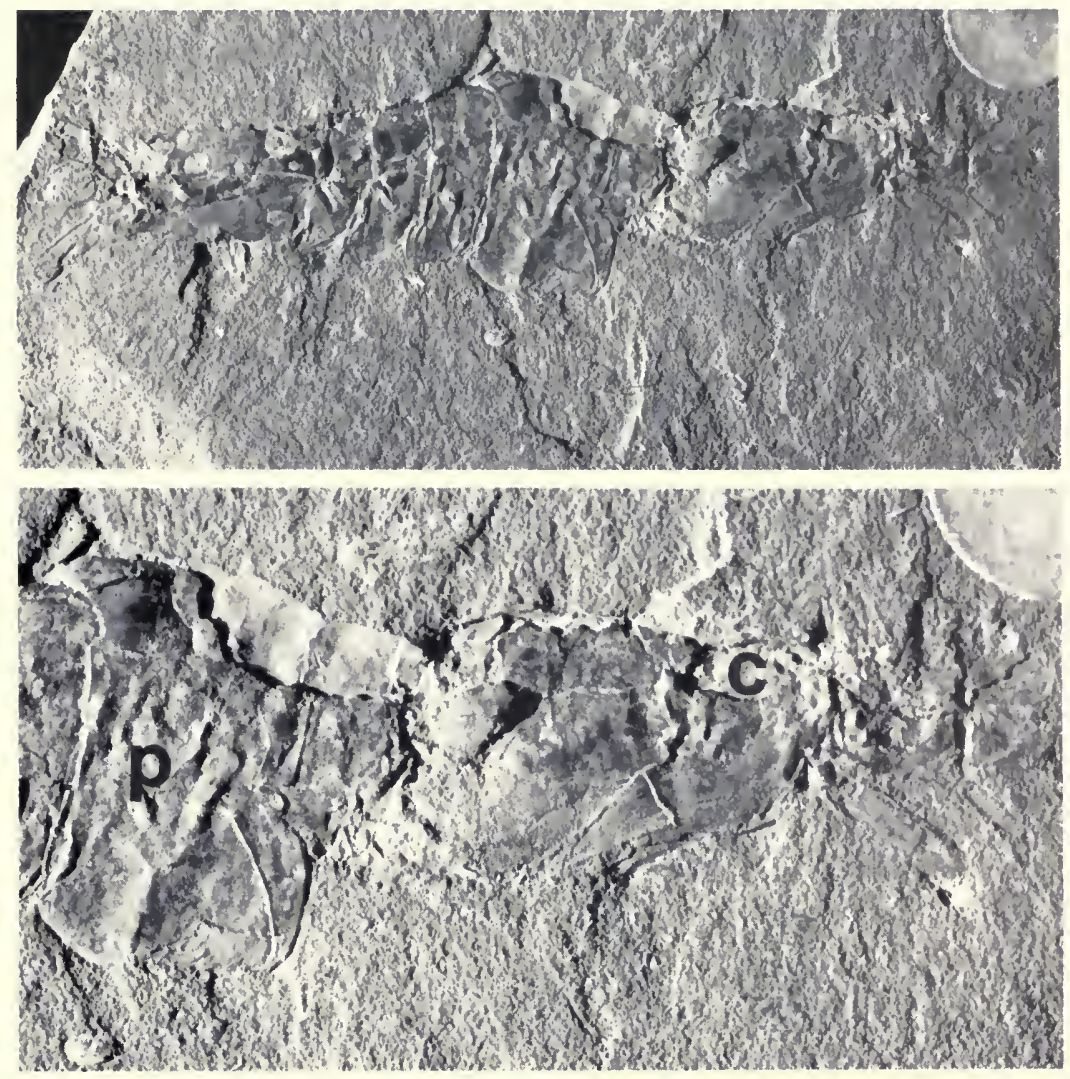

FIG. 11. Crangopsis eskdalensis (Peach), 1882. A, GSE 5007, lectotype, $2.8 \times$. B, GSE 5007 with second pleomere (p), carapace (c) and basal parts of antennal peduncles, $5.7 \times$.

served in its entirety on any of the examined specimens. The second antennal peduncle has a shcrt basal segment followed by a segment twice as long as the first segment. The eye is small and oval ( $R$ 1957.1.5110).

Only remnants of the thoracopods preserving no structural details have been seen (GSE 5843, 5844, 5845).

The abdomen is 2 to $2 \frac{1}{2}$ times the length of the cephalothorax (GSE 5848). Pleomeres 1, 3, 4, and 5 are about equal in length, while pleomere 2 is very large. The pleuron of the second pleomere is more inflated anteriorly than posteriorly, while being blunt and flattened on its ventral margin. The pleura of abdominal segments 3 , 4 , and 5 are broadly rounded posteriorly and slightly attenuated at their 
TABLE 5. Measurements in centimeters of some representative specimens of $\mathrm{Cran}$ gopsis eskdalensis. (Some specimens have more than one individual on them.) **indicates lectotype.

\begin{tabular}{|c|c|c|c|c|c|c|c|c|}
\hline \multirow[b]{2}{*}{ specimen } & \multirow[b]{2}{*}{ carapace } & \multirow[b]{2}{*}{$\begin{array}{c}\text { total } \\
\text { abdomen }\end{array}$} & \multicolumn{6}{|c|}{ abdominal segments } \\
\hline & & & $\Gamma_{a 1}$ & a2 & a3 & a4 & a5 & a6 \\
\hline GSE $5007 * *$ & .80 & 1.98 & .14 & .42 & .23 & .23 & .25 & .70 \\
\hline GSE 5841 & & 2.0 & .18 & .44 & & & & .60 \\
\hline GSE 5844 & .82 & 2.25 & .25 & .52 & .30 & .28 & .28 & .62 \\
\hline GSE 5845 & .78 & & & & & & & \\
\hline GSE 5846 & .70 & 1.72 & & & & & & \\
\hline GSE 5846 & .72 & & & & & & & \\
\hline GSE 5846 & & 1.58 & & & & & & \\
\hline GSE 5846 & .73 & & & & & & & \\
\hline R 1892.96 .2 & & 2.52 & & & & & & \\
\hline R 1957.1.5110 & .77 & 1.95 & & & & & & \\
\hline E 13497 & .96 & 2.55 & & & & & & \\
\hline Е 13499 & .85 & & & & & & & \\
\hline I 524 & .60 & 1.50 & & & & & & \\
\hline I 524 & 1.04 & & & & & & & \\
\hline$\overline{\mathbf{x}}$ & .79 & 2.0 & & & & & & \\
\hline
\end{tabular}

antero-ventral corners. These pleura broadly overlap the next posterior segments. The sixth pleomere is greatly elongated. The pleopods are thin and flap-like (GSE 5843, 5845) and are slightly wrinkled in preservation. The telson is generally poorly preserved but seems to have been short and ovoid (GSE 5841, 5843) with possibly some terminal marginal spines (GSE 5841). The exopods of the uropods are long and blade-like (GSE 5844), while the endopods seem to be broad and somewhat shorter (GSE 5007). 
Family: Kallidecthidae Schram, 1969b

Diagnosis.-Rostrum articulated. Second maxilla as an elongate stenopod. Pleopods unspecialized.

Kallidecthes Schram, 1969b. Figures 12-14. Table 6.

Type species. - Kallidecthes richardsoni Schram, 1969b. Peabody Coal Company Pit 11, Will County, Illinois; Francis Creek Shale, Middle Pennsylvanian (Westphalian C).

Kallidecthes eagari sp. nov.

Etymology. - The species is named in honor of Dr. Michael Eagar, Manchester University Museum, Keeper of Geology, who went out of his way to assist me with stratigraphic and locality ciata, and in attempting to trace down missing types and collections.

Holotype.-In 36148 (fig. 12a); near Bathing Pool, Bude, Cornwall; Culm Measures, Westphalian A.

Diagnosis.-Carapace subtriangular with attenuated posteroventral corners. No apparent rostrum but an antero-medial keel on carapace. Abdominal pleura well developed posteriorly with a straight hindmost edge.

Description.-The carapace is smooth and unornamented except for a slight middorsal keel on its most anterior aspect (In 36143, fig. 13; In 36146). The first antennae seem to be relatively short, but with wide peduncular segments (In 37971), of which there are at least two, and these subequal. The second antennal peduncles (In 36143) are long: with a short proximalmost segment, a second segment 4 to 5 times the length of the first, and the third about 3 times the length of the first. These segments are marked with faint longitudinal ridges. The mandible is large and massively developed and is preserved on most of the specimens. The first maxilla is not unusually developed but the second is very long (almost as long as a thoracopod). No eyes have been noted on any of the specimens at hand.

The thoracopods are all the same structurally (In 36142, fig. 12b; In 36143,36146$)$. Two small basal segments have been noted. These were followed distally by a moderately long "ischiomerus," a "carpus" about twice as long as the "ischiomerus," and after the knee a subequal "propodus" and "dactylus," each about the size of the "ischiomerus." There is a faint suggestion (In 36143) that these segments may have had setiferous posterior margins. 

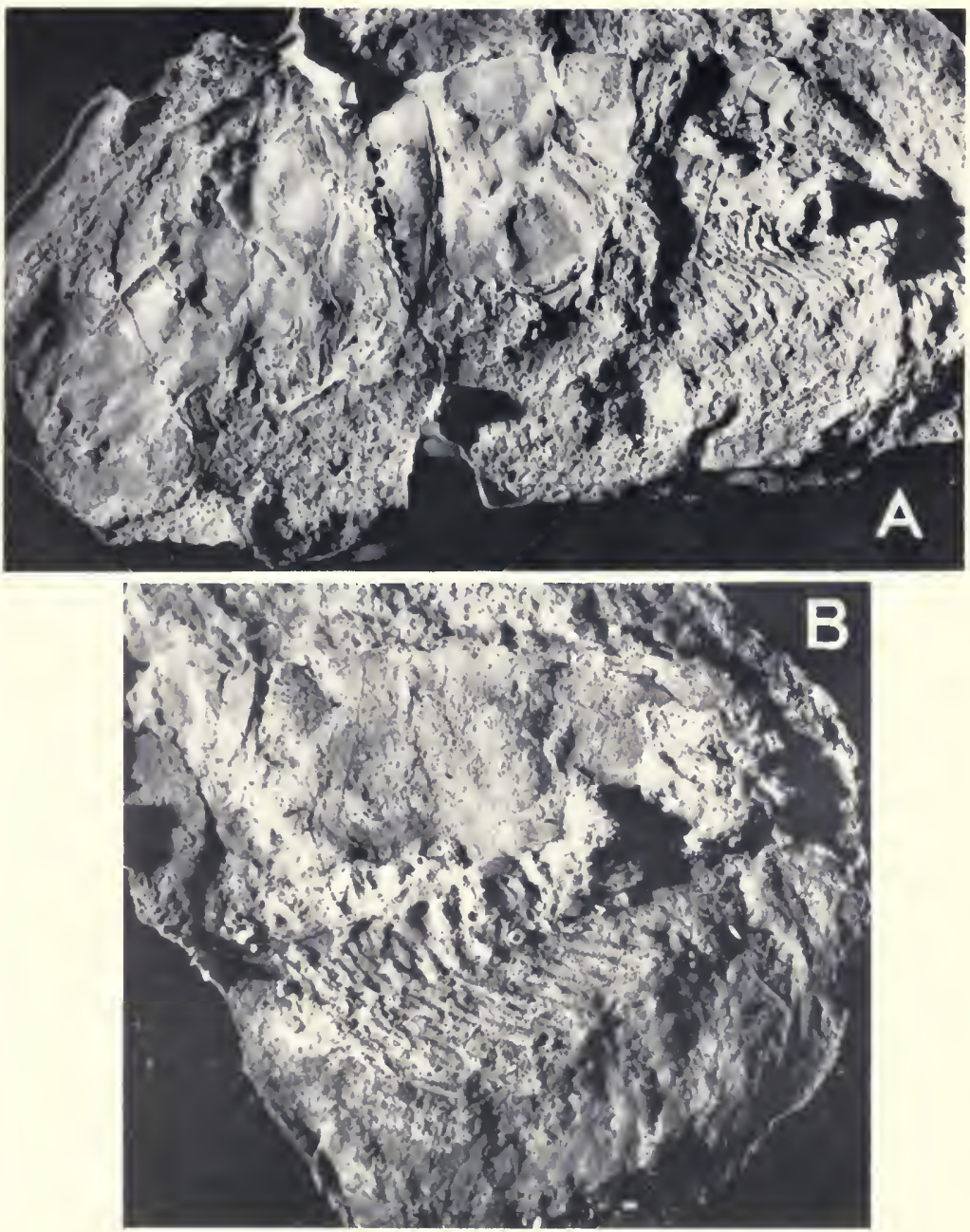

Fig. 12. Kallidecthes eagari, sp. nov. A, In 36148, holotype (latex mold), $1.2 \times$. B, In 36142 , latex mold of carapace and proximal parts of thoracopods, $3.3 \times$.

Pleomeres $1,3,4$, and 5 are subequal, the second and sixth are much elongated over these. The pleuron of the second pleomere is rounded anteriorly and posteriorly. The pleura of the posterior pleomeres (In 31866) are markedly extended posteriad with a straight hindmost edge. The sixth pleomere is elongate and narrows posteriorly. Nothing is known concerning the pleopods, telson, or uropods. 


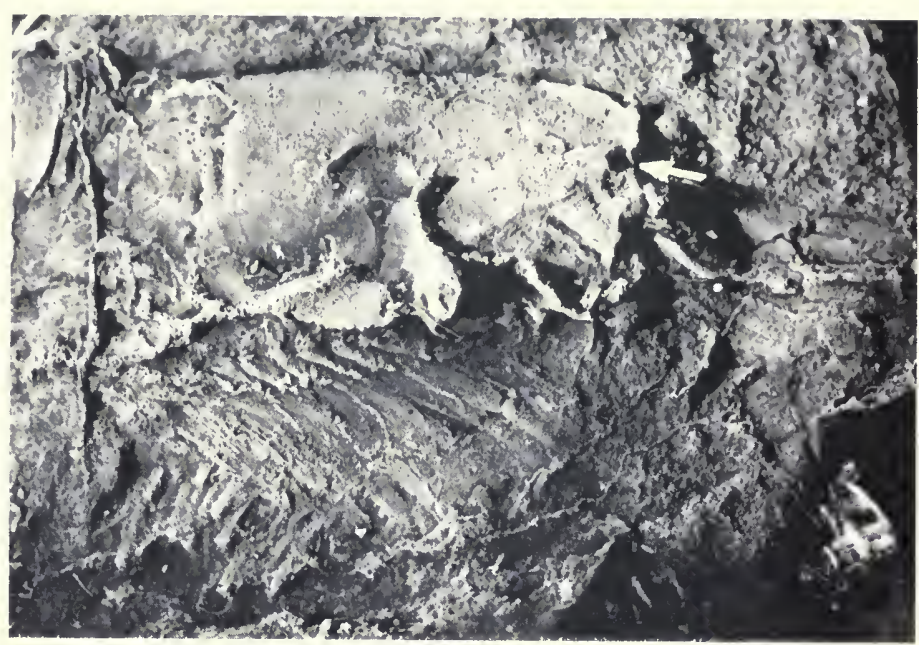

FIG. 13. Kallidecthes eagari sp. nov., In 36143 , latex mold of thorax with arrow indicating antero-median keel on carapace, $3.5 \times$.

Remarks. - These specimens are preserved in light, almost tufflike concretions from the Culm Measures from a site near the Bude Bathing Pool, Cornwall. They were collected by H. V. Corley and F. W. Wonnacolt and acquired by the BM(NH) in the late 1930's and early 1940's.

This is one of the few species from the more marine aspects of the British Upper Carboniferous. The marine faunas of the Upper Carboniferous (Pennsylvanian) are known mainly from the North American material.

The relationship to the American species Kallidecthes richardsoni of the Illinois Pennsylvanian is based on the shared development of the second maxilla as a stenopod almost as large as the first thoracopod, which is quite unlike Crangopsis. The diagnosis of Kallidec-

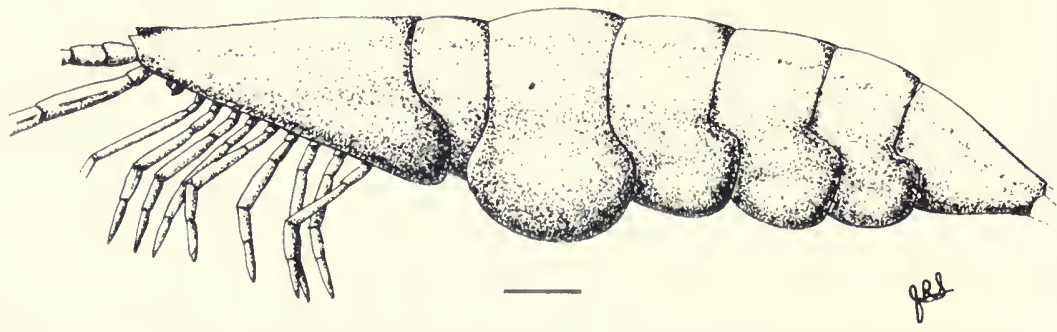

FIG. 14. Kallidecthes eagari sp. nov., resonstruction, scale $5 \mathrm{~mm}$. 
TABLE 6. Measurements of some representative specimens of Kallidecthes eagari. *indicates holotype.

\begin{tabular}{|c|c|c|c|c|c|c|c|c|}
\hline \multirow[b]{2}{*}{ specimen } & \multirow[b]{2}{*}{ carapace } & \multirow{2}{*}{$\begin{array}{c}\text { total } \\
\text { abdomen }\end{array}$} & \multicolumn{6}{|c|}{ abdominal segments } \\
\hline & & & al & a2 & a3 & a 4 & a5 & a6 \\
\hline In $36148^{*}$ & 2.03 & 4.95 & .65 & 1.0 & .93 & .82 & .68 & .80 \\
\hline In 31865 & 1.87 & 4.50 & & & & & & \\
\hline In 31866 & 1.96 & 4.15 & .50 & .85 & .70 & .65 & .62 & .94 \\
\hline In 31991 & 1.68 & 4.22 & & & & & & \\
\hline In 36142 & 1.75 & 4.05 & & .77 & .67 & .60 & .48 & .96 \\
\hline In 36143 & 1.60 & & & & & & & \\
\hline In 36144 & 1.63 & & & & & & & \\
\hline In 36146 & 1.17 & & & & & & & \\
\hline In 37961 & 1.64 & & & & & & & \\
\hline In 61407 & & 4.20 & & & & & & \\
\hline & 1.71 & 4.34 & & & & & & \\
\hline
\end{tabular}

thes richardsoni Schram, 1969b should designate it as having a rostrum, a long, thin first antennal peduncle, small-to-moderate second antennal peduncle, and slightly developed abdominal pleura. $K$. eagari bears some significant differences from the American species in regard to the antennae size and pleura development on abdominal segments. The poor preservation of the $K$. eagari material is undoubtedly due to the nature of the concretions (see section on localities). Some measurements of representative specimens are given in Table 6, a reconstruction in Figure 14.

Order: Palaeostomatopoda Brooks, 1962b

Family: Perimecturidae Peach, 1908

Perimecturus Peach, 1908

(=Palaesquilla Peach and Horne, 1903, nom. nud.)

Type species.-Anthrapalaemon parki Peach, 1882. Glencartholm, Dumfriesshire; Calciferous Sandstone Measures. 
Diagnosis.-Palaeostomatopod with dorso-ventrally flattened body. Carapace and abdominal segments decorated with longitudinal ridges. Telson broadly triangular with a terminal spike flanked by small caudal furca.

\section{Perimecturus parki (Peach), 1882. Figures 15-18. Table 7.}

v*. 1882 Anthrapalaemon parki Peach, p. 78, pl. 9, fig. 4-4g.

? 1903 Palaesquilla parki (Peach). Peach and Horne, p. 846.

v. 1908 Perimecturus parki (Peach). Peach, p. 40, pl. 5, figs. 1-5.

v. 1908 Perimecturus parki duplicarinatus Peach, p. 41, pl. 5, fig. 6 .

v.? 1908 Perimecturus stocki Peach, p. 42, pl. 6, fig. 1.

v. 1908 Perimecturus communis Peach, p. 47, pl. 7, figs. 1-5.

1911 Perimecturus parki (Peach). Woodward, p. 363.

1911 Perimecturus parki duplicarinatus Peach. Woodward, p. 363.

1911 Perimecturus stocki Peach. Woodward, p. 363.

1911 Perimecturus communis Peach. Woodward, p. 363.

? 1969 Perimecturus parki (Peach). Brooks, p. R535, fig. 342, 1 b.

1969 a Perimecturus parki (Peach). Schram, p. 217, table 1.

1969 a Perimecturus stocki Peach. Schram, p. 217, table 1.

1969a Perimecturus communis Peach. Schram, p. 217, table 1.

Lectotype (here designated).-GSE 5896 (fig. 15); River Esk, Glencartholm 11/2 miles below Langholm Dumfriesshire; Glencartholm Volcanic Beds, Calciferous Sandstone Measures.

Diagnosis. - Carapace and abdominal tergites with four ridges, two medial and two lateral. Margins of tail fan decorated with diaphanous setae. Telson spike less than half of telson base.

Description.-This is a very large palaeostomatopod with a dorsoventrally flattened body. The carapace is roughly rectangular when seen dorsally and has a marked doublure all around its margins (GSE 5896, fig. 15a). Two pairs of lateral, longitudinal ridges decorate the carapace. The rostrum is articulated and rather bluntly pointed (GSE 5896). Only GSE 5898 preserves part of the antennae and these are incomplete. The flagella of both antennae are apparently short. The exact number and arrangement of peduncular segments is not clear. The scaphocerite is elongate and pointed on its disto-lateral tip.

All the thoracomeres are covered by the carapace, but at least the posterior segments are not fused to it. The thoracopods are subchelate and, although a number of specimens are preserved in lateral aspect so as to display the appendages (GSE 5874, fig. 16a), these structures are typically drawn up and superimposed over each other making detailed study almost impossible. All the thoracopod 


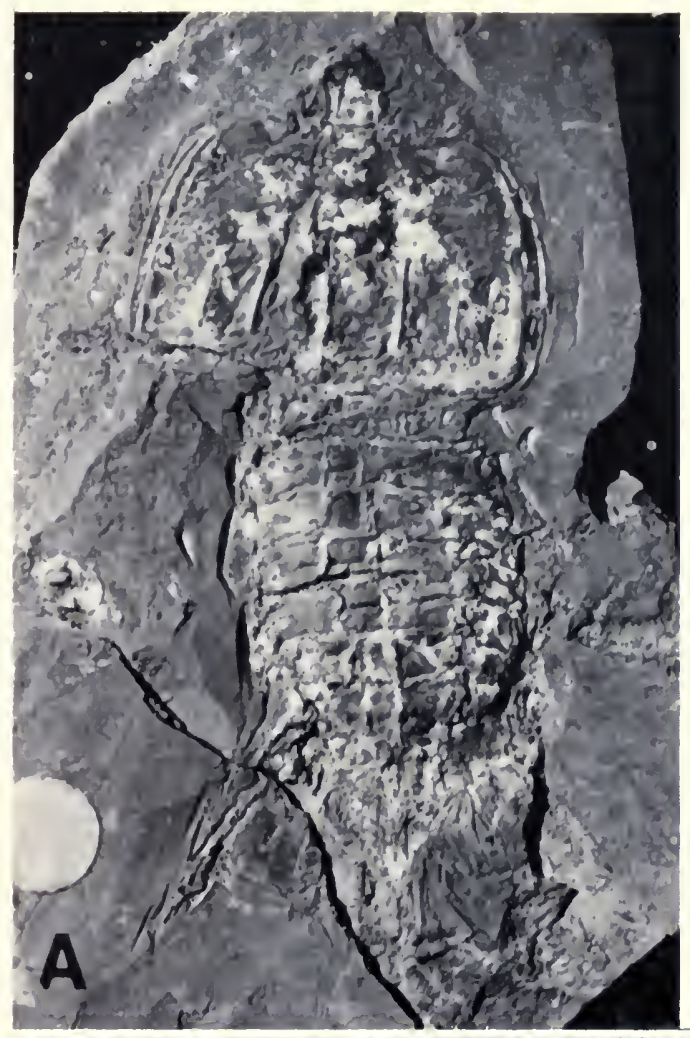

FIG. 15. Perimecturus parki (Peach), 1882. A, GSE 5896, lectotype, 1.5 $\times$. B, GSE 5892, tailfan with long flexible setae on uropod, photographed under water, $2.7 \times$.

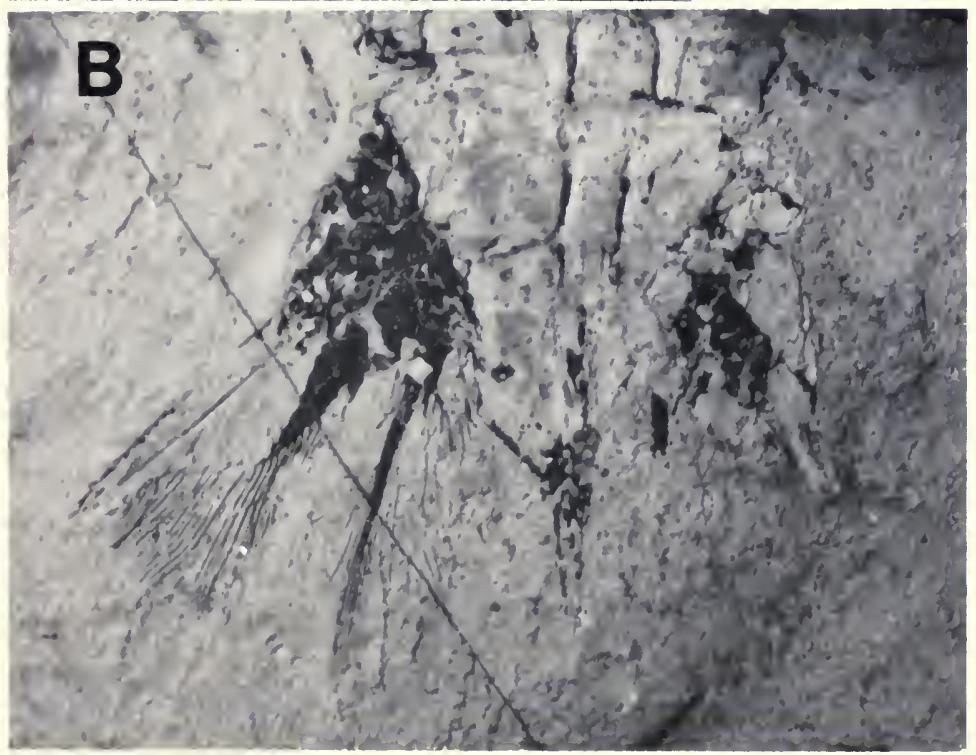



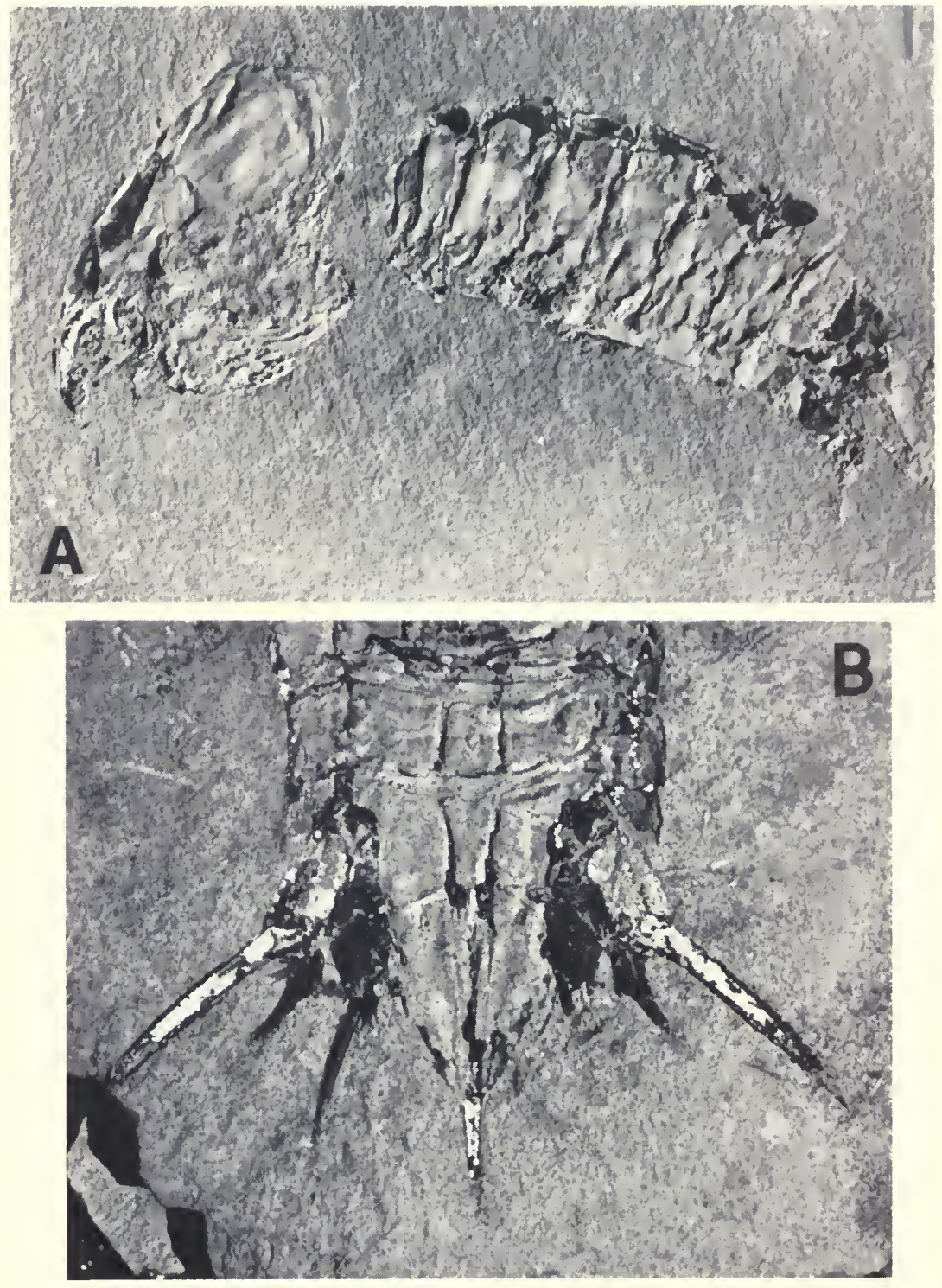

FIG. 16. Perimecturus parki (Peach), 1882. A, GSE 5874, lateral preservation with subchelate thoracopods visible ventral to carapace, $2.5 \times$. B, GSE 5902 , tailfan and median ridges on pleomeres., $2.5 \times$. 


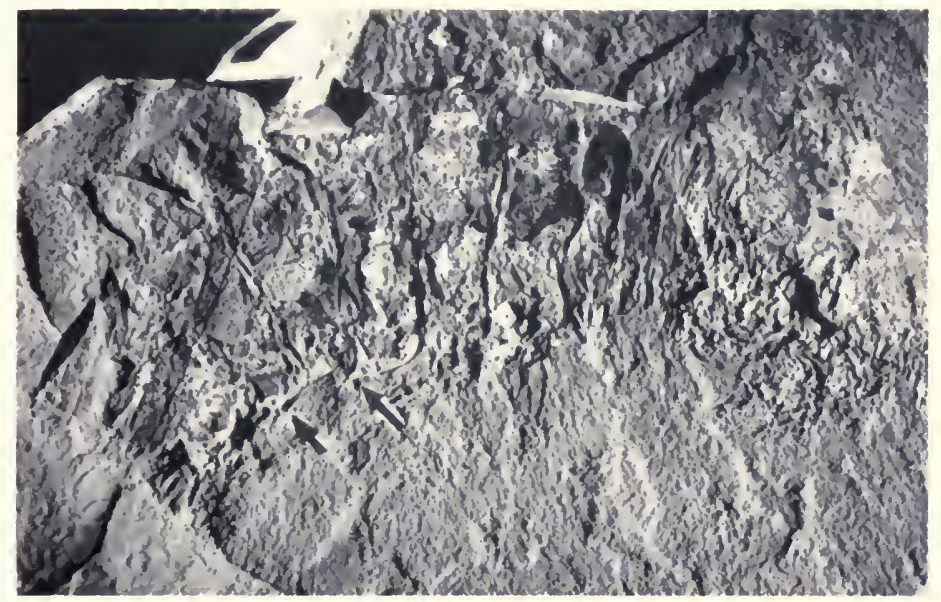

FIG. 17. Perimecturus parki (Peach), 1882. GSE 5006, arrow pointing to posteriorly directed spine on abdominal pleuron, $1.8 \times$.
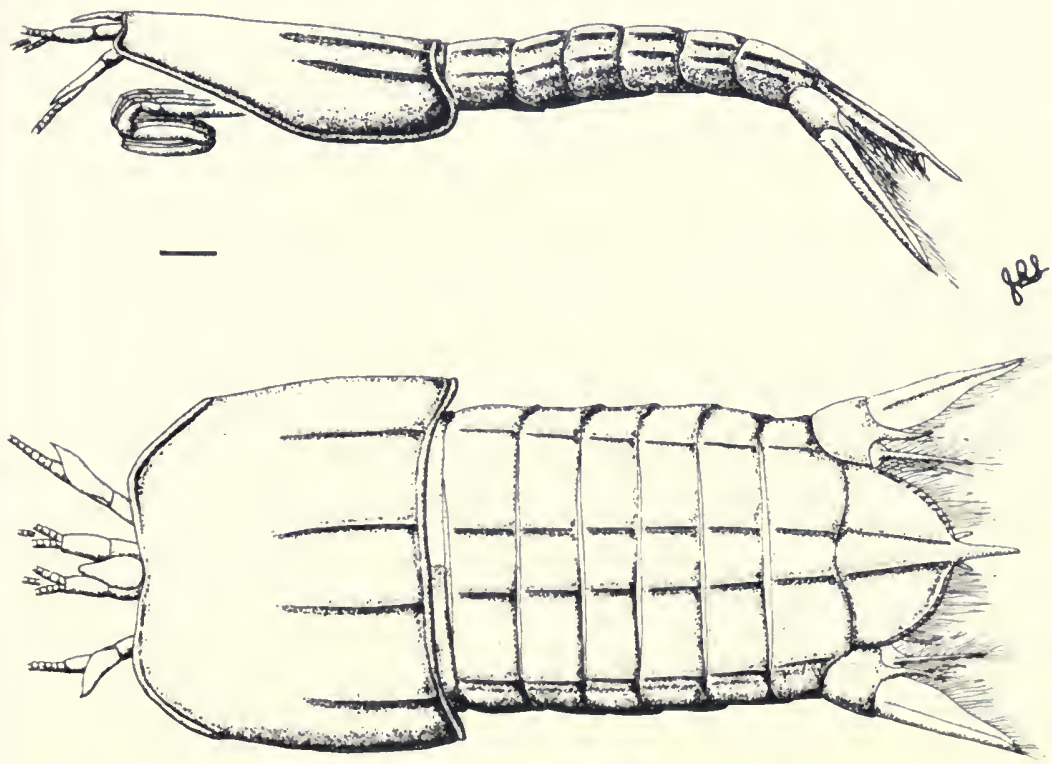

FiG. 18. Perimecturus parki (Peach), 1882, reconstruction, scale $5 \mathrm{~mm}$. 


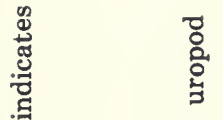

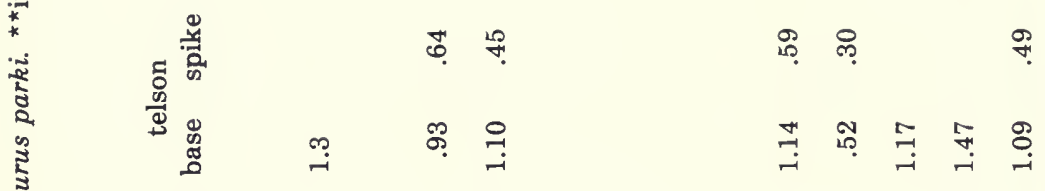

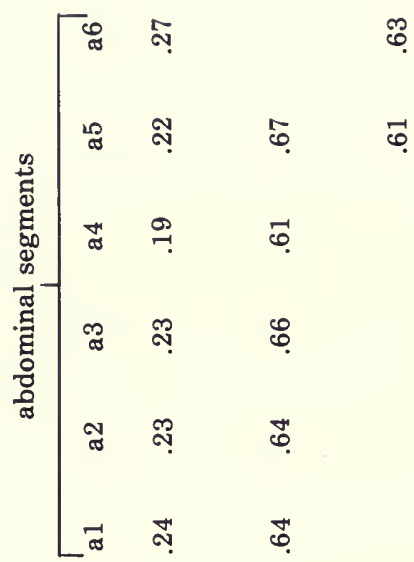

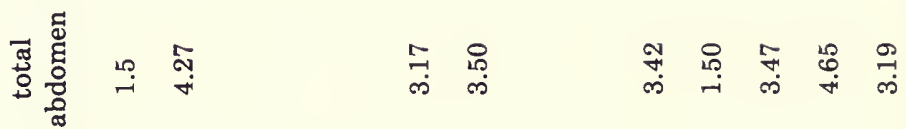

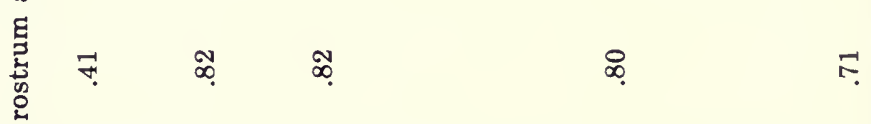

$$
\begin{aligned}
& \text { 总 }
\end{aligned}
$$

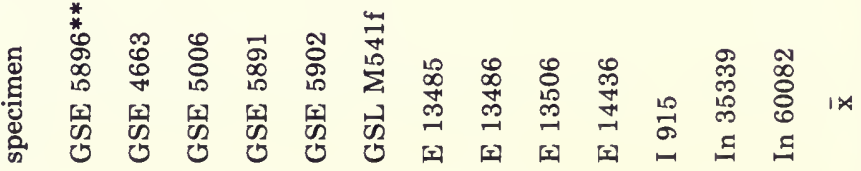


segments seem to be roughly equal in length except for the fourth from the distal end which is significantly shorter than all the rest.

The abdominal segments are all equal in length and are decorated with two pair of longitudinal ridges, one pair close to the midline and the other placed more laterally. The abdominal pleura are armed with terminal posteriorly decorated spines (GSE 5006, fig. 17; GSE $5898,5891)$.

The telson is broadly triangular with the apex developed as a spike. The spike is typically less than half the length of the telson base. The base of the telson is decorated with a pair of longitudinal ridges that approach each other toward the base of the spike. Small furca flank the spike base. GSE 4663 and 5891 indicate that the telson is adorned with two series of long, flexible, delicate setae; one set arising from along the margin and the other from a secondary ridge on the dorsal surface which parallels the margin. The protopod of the uropod has a median dorsal projection extending posteriad between the exopod and endopod base (GSE 5894, 5902, fig. 16b). The exopod has a heavy, blade-like lateral margin which extends mediad as a thin, membranous flap whose margins are adorned with delicate setae as on the telson. The uropod endopod is a thin, moderately sclerotized process with very thin, membranous wings restricted toward the base. The membranous and spinous portions carry the characteristic long, delicate setae. The entire effect of the tail fan of this species (GSE 5892, fig. 15b) is one of great delicacy and beauty.

Remarks.-Perimecturus parki is among the largest of all the Paleozoic hoplocaridans. The largest specimen (GSE 5897) is some $15 \mathrm{~cm}$. in total length. The multiplicity of species Peach (1908) included in this taxon is due to faulty interpretation of modes of preservation, with $P$. parki a typical dorso-ventrally flattened fossil; $P$. parki duplicarinatus a specimen with the longitudinal ridges sharply marked; $P$. communis as lateral compressions; and $P$. stocki a single, large, somewhat obliquely oriented individual.

Measurements are given in Table 7, a reconstruction in Figure 18.

Bairdops gen. nov.

Type species.-Perimecturus elegans (Peach), 1908. Glencartholm, Calciferous Sandstone Measures.

Diagnosis.-Palaeostomatopod with circular or oval body crosssection. Carapace rectangular in lateral outline. Cuticle generally 

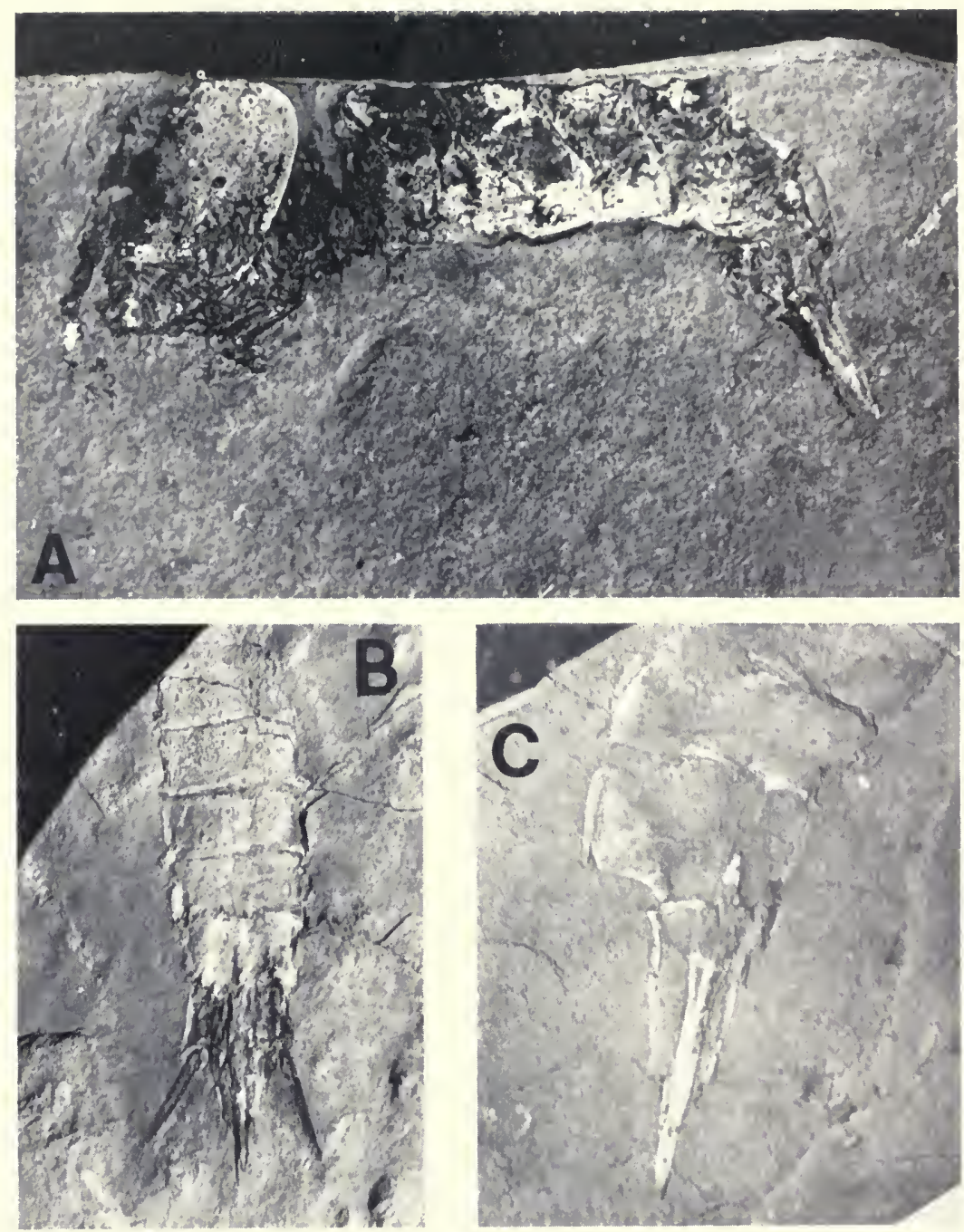

FIG. 19. Bairdops elegans (Peach), 1908. A, GSE 5879, lectotype, $2.1 \times$. B, GSE 5884 , posterior of abdomen and tailfan, $2.4 \times$. C, GSE 5886 , telson with median ridge and characteristic form of telson base and spike, $2.8 \times$.

smooth and undecorated. Telson base rectangular and elongate with terminal spike developed posteriorly. Uropods blade-like.

Etymology.-Genus named in honor of William J. Baird, Assistant Curator of the fossil invertebrate collection, Royal Scottish Museum, Edinburgh. 
Bairdops elegans (Peach), 1908. Figures 19-21. Table 8.

$\mathrm{v}^{*}$. 1908 Perimecturus elegans Peach, p. 44, pl. 6, figs. 2-6.

v. 1908 Perimecturus ensifer Peach, p. 49, pl. 7, figs. 8-14.

1911 Perimecturus elegans Peach. Woodward, p. 363.

1911 Perimecturus ensifer Peach. Woodward, p. 363.

? 1962b Perimecturus elegans Peach. Brooks. p. 210, pl. 8c.

? 1969 Perimecturus elegans Peach. Brooks, p. R535, figs. 341, 1; 342, 1a.

1969a Perimecturus elegans Peach. Schram, p. 217, table 1.

1969a Perimecturus ensifer Peach. Schram, p. 218, table 1.

Lectotype (here designated).-GSE 5879 (fig. 19a); Glencartholm, River Esk, 11/2 miles below Langholm, Dumfriesshire; Glencartholm Volcanic Beds, Calciferous Sandstone Measures.

Diagnosis.-Margins of abdominal pleura smooth and broadly rounded. Margins of tailfan undecorated with spines or setae. Telson spike at least half the length of entire telson.

Description. - This animal is a palaeostomatopod of moderate to large size. The cuticle is thin and smooth. The rostrum is long and rounded (GSE 5883) and the carapace has only the slightest doublure on the lateral margins. Little can be discerned concerning the thoracopods on any of the specimens examined, with segments of

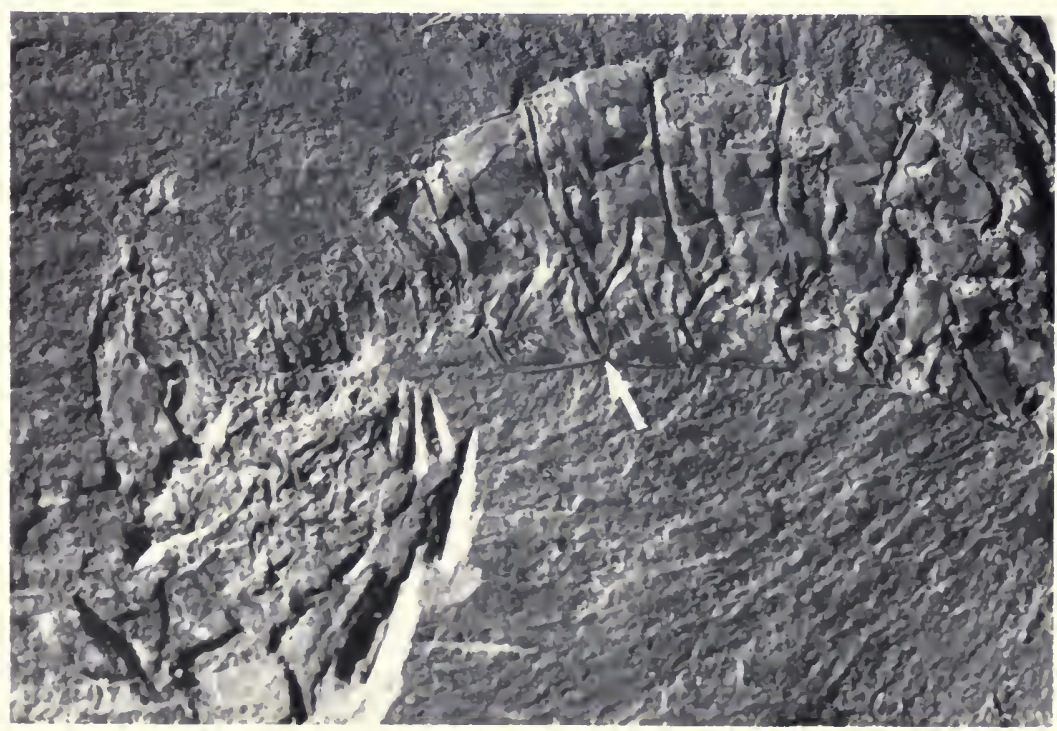

FIG. 20. Bairdops elegans (Peach), 1908. GSE 5881, arrow pointing to rounded posterior corner of the abdominal pleuron, $3.1 \times$. 


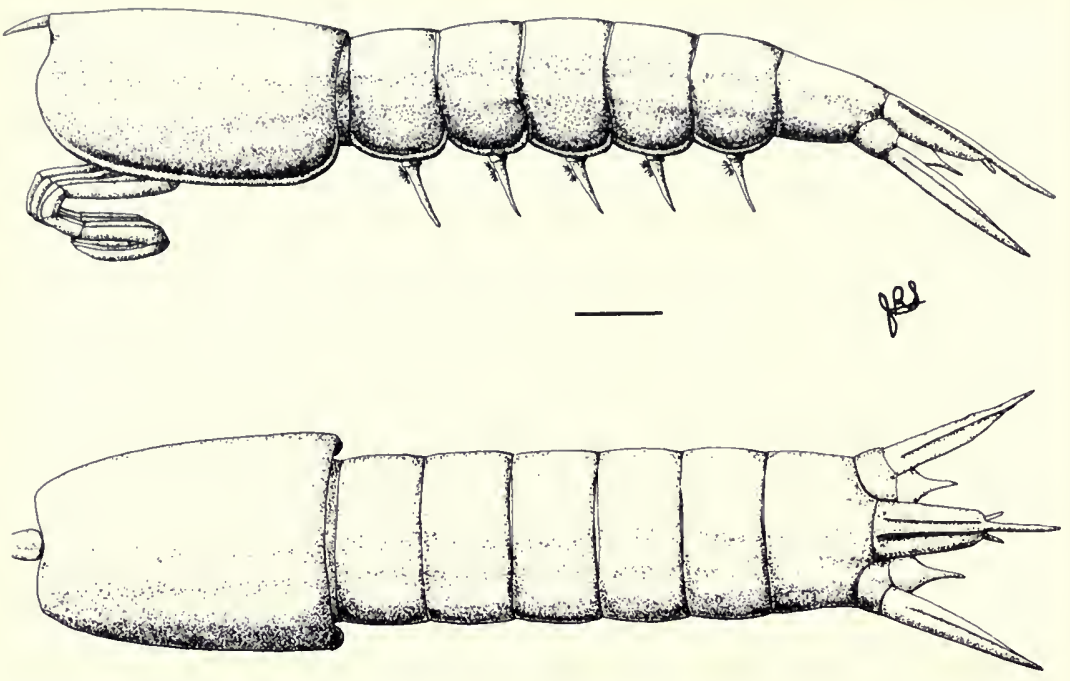

Fig. 21. Bairdops elegans (Peach), 1908. Reconstruction, scale $5 \mathrm{~mm}$.

these appendages subequal except for the fifth segment from the distal end which is much longer than any of the others.

The abdominal segments are equal in length. The pleopods are thin and flap-like and GSE 5876 preserves tuft-like structures on the pleopods in the position in which the gills would be expected for a hoplocarid. The telson base is long and rectangular. Not quite half way along its length the telson reduces its width abruptly and continues posteriad as a spike. The telson is marked with a slight, broad, middorsal ridge which blends into the spike (GSE 5886, fig. 19c). Small furca arise near the base of the spike (GSE 5884, fig. $19 \mathrm{~b})$. The abdominal pleura are broadly rounded with slight marginal doublures (GSE 5881, fig. 20).

The protopod of the uropod is plain and rectangular with only the slightest suggestion of a mid-dorsal spike directed posteriad (GSE 5877). The exopod is long and blade-like (In 60088) with its lateral margin more sclerotized than the medial. The endopod is quite reduced (GSE 5882, 5884).

Remarks. - The reconstruction of Perimecturus elegans prepared by Brooks $(1962 \mathrm{~b}, 1969)$ seems to be based on specimens which include $P$. parki. That reconstruction is thus a composite of characters of $P$. parki, Bairdops elegans, and probably P. pattoni (see below) as well. 


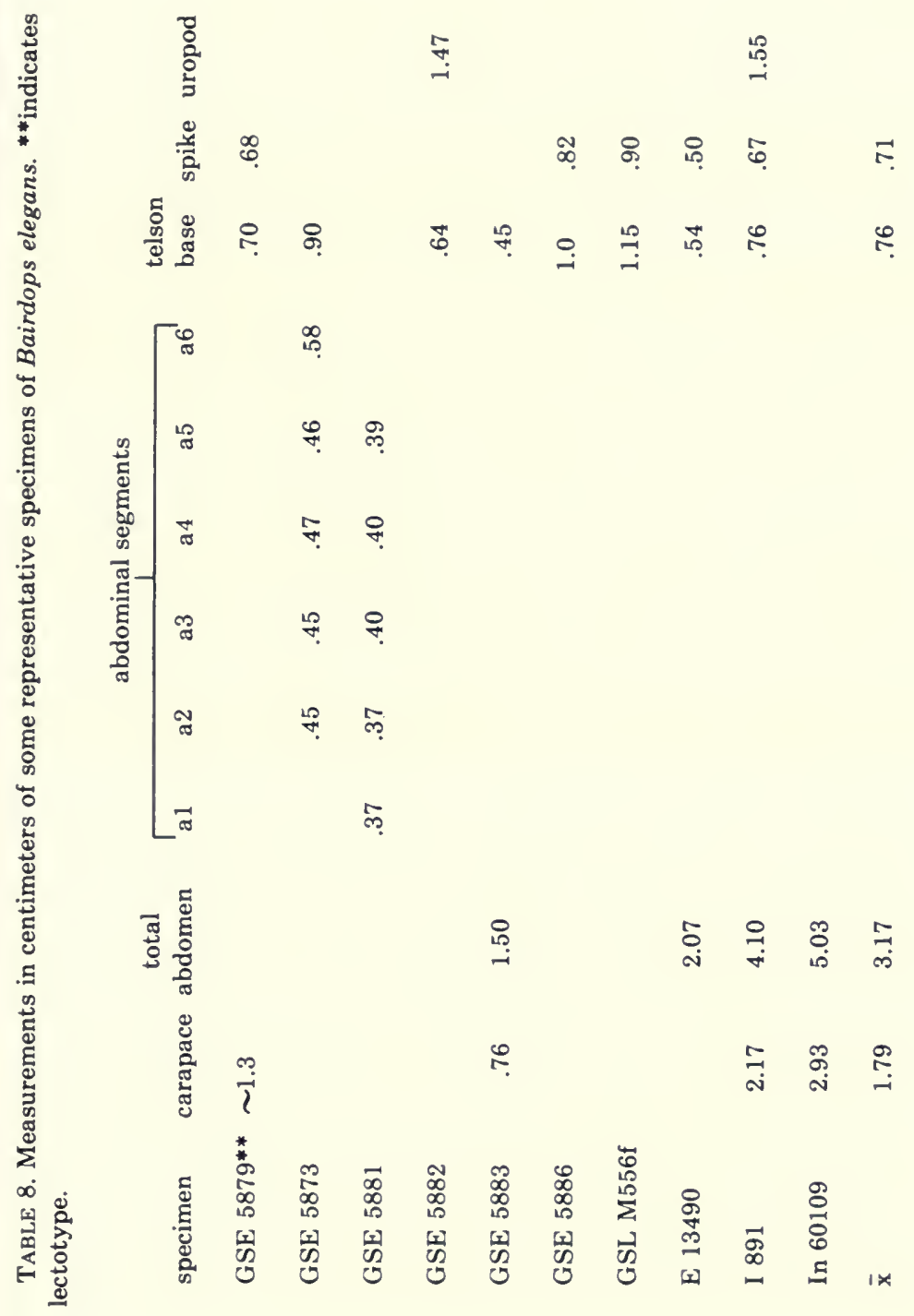


Bairdops elegans is placed in a genus separate from Perimecturus based on the very distinctive difference of the tailfan, body shape, and size. Bairdops appears to be actually more closely allied to the North American genus Archaeocaris Brooks, 1962b. Bairdops differs from Archaeocaris in having a more rectangular carapace, broader pleomere pleura, prominently spiked telson, and blade-like uropods.

Measurements of $B$. elegans are given in Table 8. A reconstruction is presented in Figure 21.

Order: incertae sedis

“Perimecturus” pattoni Peach, 1908. Figure 22.

v. 1908 Perimecturus pattoni Peach, p. 41, pl. 6 fig. 9.

1969 a Perimecturus pattoni Peach. Schram, p. 218, table 1.

Holotype.-(by monotypy) R 1887.25.1059; East Kilbride, Lanarkshire; Shale over the Top Hosie Limestone, Limestone Coal Group, Carboniferous Limestone Measures.

Remarks. -The original description of this species was based on one specimen, $\mathrm{R} 1887.25 .1059$ (fig. 22). It is relatively small, $2.8 \mathrm{~cm}$. in total length. The carapace does not cover the three most posterior thoracomeres. The overall preservation may indicate that this

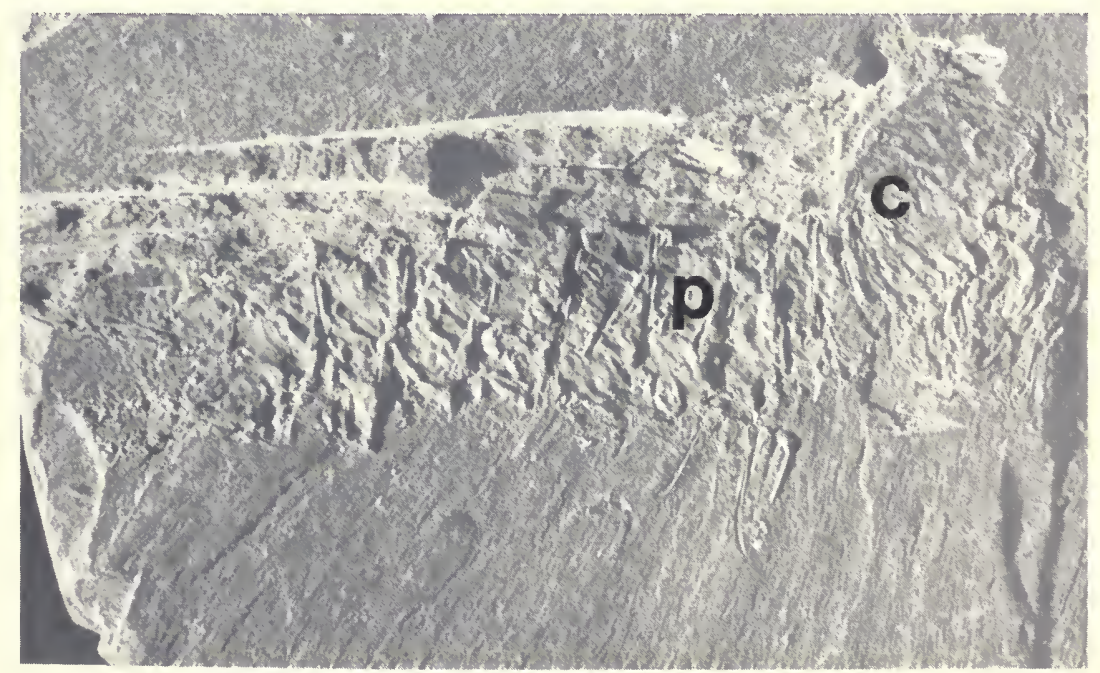

FIG. 22. "Perimecturus" pattoni Peach, 1908. R 1887.25.1059, the only known specimen of this species, carapace (c), first pleomere $(p), 3.7 \times$. 
posterior thoracic exposure is not entirely due to preservation distortion, but is possibly a natural arrangement. There are also distinctive flap-like appendages on these exposed thoracomeres. My intuition tells me this fossil is that of a tyrannophontid stomatopod. However, with only one specimen, and that of indifferent preservation, I hesitate to propose a generic name for it. For the time being, I choose to leave this specimen "incertae sedis."

\section{Subclass: Eumalacostraca Grobben, 1892}

Superorder: Eocarida Brooks, 1962b

Order: Eocaridacea Brooks, 1962b

Remarks.-Schram (1974a, b) suggested that with the removal of the pygocephalomorphs to the mysidacean peracarids, eventually the other eocarids might be placed in known "schizopod" groups. It seems now that though this might be theoretically possible it has still not proved practical. It seems prudent to retain Eocaridacea for these rather non-descript caridoid forms. It should be recognized that some of these species may be truly euphausiacean or mysidacean types. But it also appears, however, that some of these forms may be neither euphausiacean nor mysidacean. The term Eocaridacea should thus be understood to mean "unassignable schizopodous caridoid." Brooks' (1962b) original characterization of the telson and "sympod" are very questionable (Schram, 1974a).

Family: Belotelsonidae Schram, 1974a

Belotelson Packard, 1886

(=Rostrocaris Peach and Horne, 1903, nom. nud.)

Type species.-Belotelson magister (Packard), 1886, Mazon Creek, Grundy County, Illinois; Francis Creek Shale, Middle Pennsylvanian (Westphalian C).

Diagnosis. - Rostrum long. Posterior mid-dorsal pore on carapace. Well-developed sternites on all thoracomeres. Thoracopods without exopods. Triangular telson with caudal furca. Diaphanous uropods.

Belotelson traquairi (Peach), 1882. Figures 23-25. Table 9.

v. 1882 Anthrapalaemon traquairi Peach, 1882, p. 80, pl. 10, fig. 5a-e.

?1903 Rostrocaris traquairi (Peach). Peach and Horne, p. 846.

vp. 1908 Anthracophausia dunsiana Peach. Peach, p. 61, pl. 9, figs. 1-7.

v. 1908 Anthracophausia traquairi (Peach). Peach, p. 67, pl. 10, figs. 1-5. 

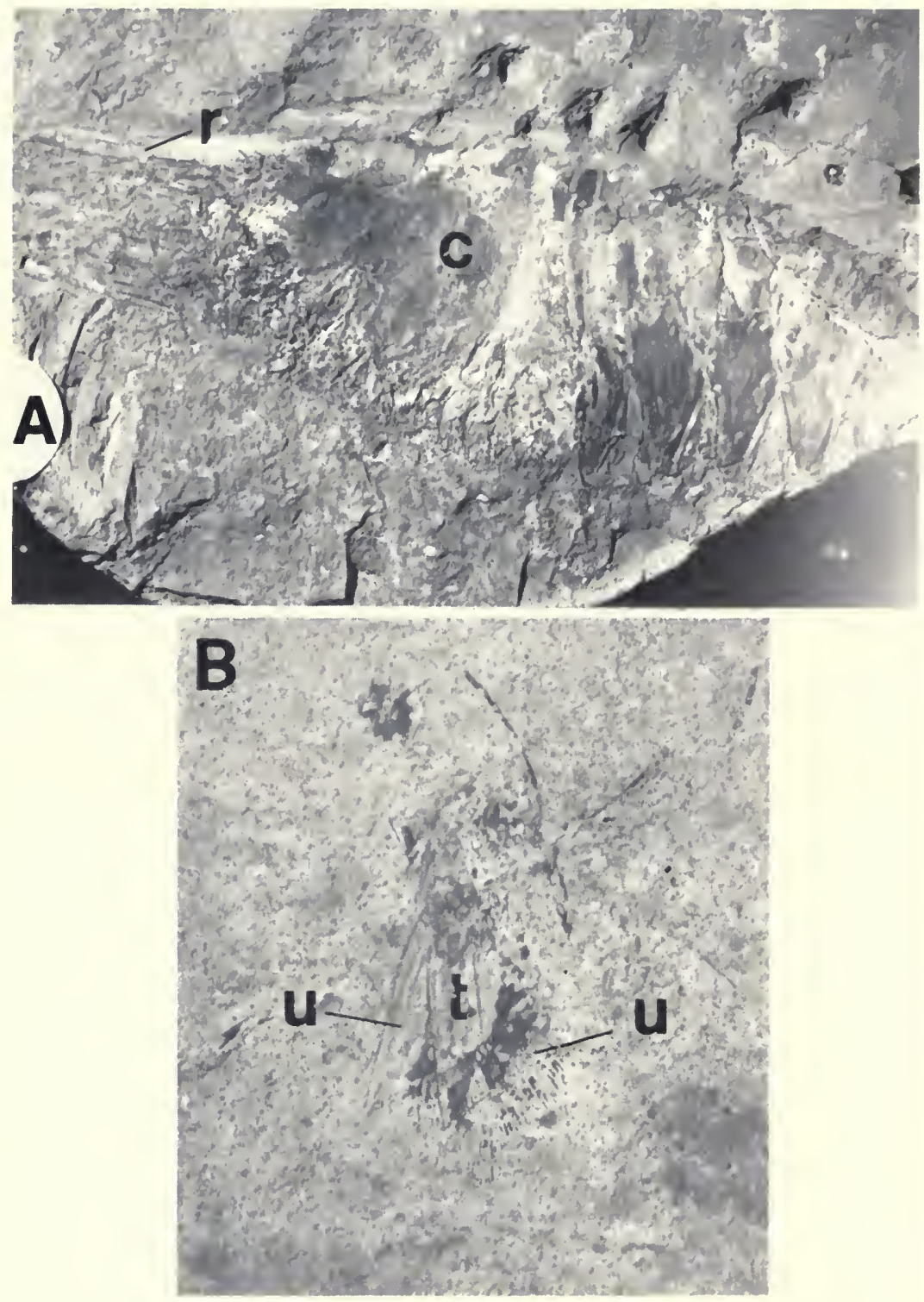

FIG. 23. Belotelson traquairi (Peach), 1882. A, GSE 5827, lectotype with rostrum (r) and carapace (c), $1.6 \times$. B, GSE 5825, tailfan with telson (t) and setose uropods (u), $3.1 \times$. 


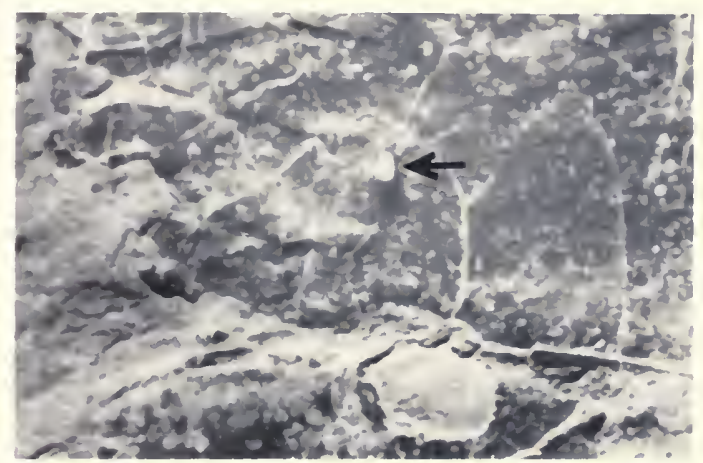

FIG. 24. Belotelson traquairi (Peach), 1882. GSE 5830, close-up of posterior mid-dorsal pore of carapace, $10 \times$.

1911 Anthracophausia traquairi (Peach). Woodward, p. 363.

1969 a Belotelson traquairi (Peach). Schram, p. 215, table 1.

1974a Belotelson traquairi (Peach). Schram, p. 30.

Lectotype (here designated).-GSE 5827 (fig. 23a); River Esk, Glencartholm, 11/2 miles below Langholm, Dumfriesshire; Glencartholm Volcanic Beds, Calciferous Sandstone Measures.

Diagnosis. - Rostrum deeper proximally than distally. Abdominal pleura rounded. Ischia of thoracopods moderately developed and wide.

Description. - This is an eocarid of moderate to large size. The exoskeleton is well sclerotized, smooth and undecorated. The carapace is not attached to the thoracomeres. The rostrum is half as long as the carapace proper (GSE 5827, fig. 23a; 5828) and is relatively deeper proximally as it arises from the carapace than it is at its distal end. The unique posterior mid-dorsal pore can be clearly seen on GSE 5009, 5827, 5828, and 5830 (fig. 24). The antennal peduncles are large and there is a prominent scaphocerite, but badly preserved, on all the specimens at hand.

The thoracopods are developed as strong endopods (GSE 5008). There are no exopods. Proximal to the longest segment of the leg is a relatively wide and moderately long segment. There is still a problem (as in B. magister, see Schram, 1974a) in determining the exact number and structure of the segments in the base of the thoracic appendages, with only three specimens (GSE 5828, 5009, 5900) displaying this area. There seem to be two segments between the wide segment mentioned above and the muscle compartments of the body evident on the side of the thorax, but the details are obscured by some extraneous matter over this region. This "debris" can be 
best seen on GSE 5900. The ventral thoracic sternites (GSE 5826) are well developed with a separatory ridge of the muscle compartments not meeting at the dorsal midline.

The abdominal pleura are well developed. These pleura are narrowly rounded and have slight doublures (GSE 5827, 5828). The tail is fan-like (GSE 5825, fig. 23b) with the setiferous uropods as diaphanous lobes, except for the sclerotized lateral margin of the exopod. The telson is subtriangular with a pair of large, diaphanous caudal lobes occupying the distal half of the telson margins.

Remarks.-The differences between $B$. traquairi and B. magister of the North American Pennsylvanian are subtle. The rostrum of $B$. traquairi is deeper at its base. The abdominal pleura of $B$. traquairi are rounded, whereas those of $B$. magister are somewhat pointed ventrally. The notches for the caudal furca on the telson of $B$. traquairi are more marked.

There also are some differences in the thoracopods of the two species, but the evidence is confusing. It was tentatively concluded (Schram, 1974a) that B. magister had proximally two short segments followed by a long segment, and after the knee, there was a short segment followed by two moderately long segments. No specimens of $B$. traquairi preserve the distalmost leg segments, so it is difficult to seek homologies, but we proximally have two short segments, followed by a moderately long and wide segment, which, in turn, is followed by a long, thin segment to the knee.

$B$. traquairi would seem to have an extra segment in the base of th:e leg over that of $B$. magister. It must be recalled that this region in all specimens of Belotelson is always poorly preserved. If we homologize the long segment in both species (probable, because of its distinctive size and relation to the knee) as a merus, the two basalmost segments on $B$. traquairi are then the coxa and basis. The ischium in the two species then varies from being short in $B$. magister to longer and wider in $B$. traquairi. A clear separation of coxa and basis was not detectable then on $B$. magister specimens.

Belotelson specimens as a whole are well sclerotized and preserved. Why should it be so difficult to decide the structure of the protopod? There may be a clue in the worm-like debris mentioned above in the area of the protopods of GSE 5900. The visual effect of this debris is to break up and almost completely obscure this area. The best interpretation of this material on an otherwise well-preserved specimen is as remnants of podomerous gills. Such gill 


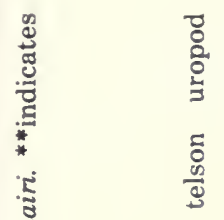

$\infty$

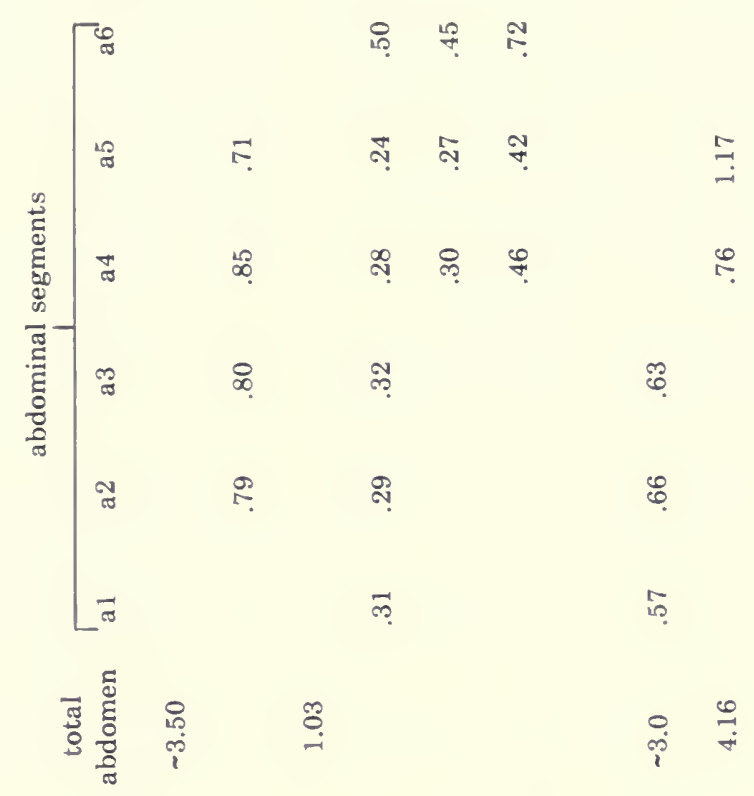

党 亡

岕

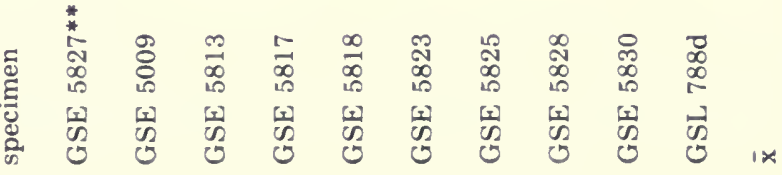




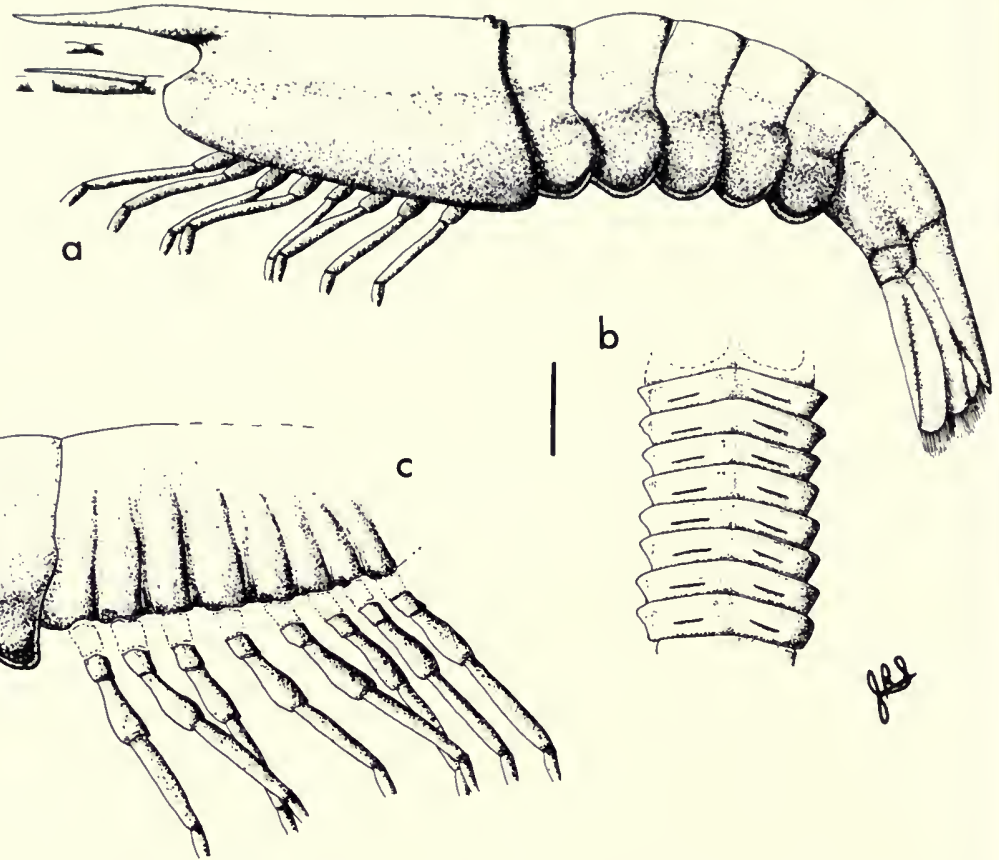

FIG. 25. Belotelson traquairi (Peach), 1882. Reconstruction, scale $5 \mathrm{~mm}$. A, Lateral view; $\mathbf{B}$, ventral view of thoracic sternites; $\mathbf{C}$, lateral view of thorax with carapace removed to show the leg bases and the muscle compartments of the body wall.

masses would be unlikely to be readily and clearly preserved, but if they occurred in sufficient mass they could effectively distort and obscure this region.

Preservation of gills is not unknown in fossil eumalacostracans (see above under Bairdops elegans, and Schram, 1969b). The possibility of gills on the leg bases raises some questions as to the taxonomic affinities of Belotelson. Schram (1974a) suggested that in toto, Belotelson resembled a reptant euphausiacean. If there are, indeed, gills on the thoracopod bases, they would serve to strengthen a euphausiacean connection, but it is also quite obvious that on some specimens of $B$. traquairi the carapace is not fused to any of the thoracomeres. This would serve to weaken a case for designating Belotelson as a euphausiacean. What I believe we have is a situation like that alluded to earlier under Eocarida, viz., that some eocaridaceans cannot be placed in either of the extant "schizopod" groups (euphausiacean or mysidacean) since they have, in effect, characters of each. In the case of Belotelson, the gills on the appen- 
dages are euphausiacean, but the carapace is peracaridan. In addition, the loss of thoracic exopods is a unique character related to a reptant habit. In short, Belotelson is neither or both depending on the characters used, and consequently eocaridacean.

Some of the material Peach referred to as Anthracophausia dunsiana is in reality Belotelson traquairi. The confusion arose from preservational differences at different geographic localities. The forms from the type locality in the Glencartholm volcanic beds along the River Esk are large and carbonized, while those from along Whiteadder Water in Berwickshire seem to be slightly smaller and have a fair amount of calcareous mineral in their exoskeletons. Measurements are given in Table 9, a reconstruction in Figure 25.

Family: Anthracophausiidae Brooks, 1962b

Anthracophausia Peach, 1908

(=Palaemysis Peach 1908)

Type species.-Anthracophausia dunsiana Peach, 1908, Glencartholm, Carboniferous Sandstone Measures.

Diagnosis.-Carapace rectangular in lateral outline. Optic notch large. Rostrum falciform. Cuticle thin. Telson somewhat dorsal to and overlying the uropods.

\title{
Anthracophausia dunsiana Peach, 1908. Figures 26-29. Table 10.
}

\author{
v 1908 Palaemysis dunlopi Peach, p. 57, pl. 8, figs. 12-14. \\ v 1908 Palaemysis couttsi Peach, p. 59, pl. 8, figs. 16-19. \\ v 1908 Palaemysis tenuis Peach, p. 60, pl. 8, figs. 20-24. \\ vp*. 1908 Anthracophausia dunsiana Peach, p. 61, pl. 9. figs. 8, 10. \\ v . 1908 Anthracophausia dunsiana obesa Peach, p. 66, pl. 9. figs. 11-15. \\ v. 1908 Crangopsis rhodesi Peach, p. 73, pl. 11, figs. 11-14. \\ ? 1908 Crangopsis magna Peach, p. 75, pl. 11, fig. 15. \\ v. 1908 Crangopsis couttsi Peach, p. 76, pl. 11, figs. 1-7. \\ ? 1908 Crangopsis hastata Peach, p. 82, pl. 11, figs. 19, 20. \\ vp. 1908 Crangopsis eskdalensis (Peach). Peach, pl. 11, fig. 14. \\ 1911 Palaemysis dunlopi Peach. Woodward, p. 363. \\ 1911 Palaemysis couttsi Peach. Woodward, p. 363. \\ 1911 Palaemysis tenuis Peach. Woodward, p. 363. \\ 1911 Anthracophausia dunsiana Peach. Woodward, p. 363. \\ 1911 Anthracophausia dunsiana obesa Peach. Woodward, p. 363. \\ 1911 Crangopsis couttsi Peach. Woodward, p. 363. \\ 1911 Crangopsis rhodesi Peach. Woodward, p. 363. \\ ? 1911 Crangopsis magna Peach. Woodward, p. 363. \\ ? 1911 Crangopsis hastata Peach. Woodward, p. 363. \\ 1969 Anthracophausia dunlopi (Peach). Brooks, p. R342.
}



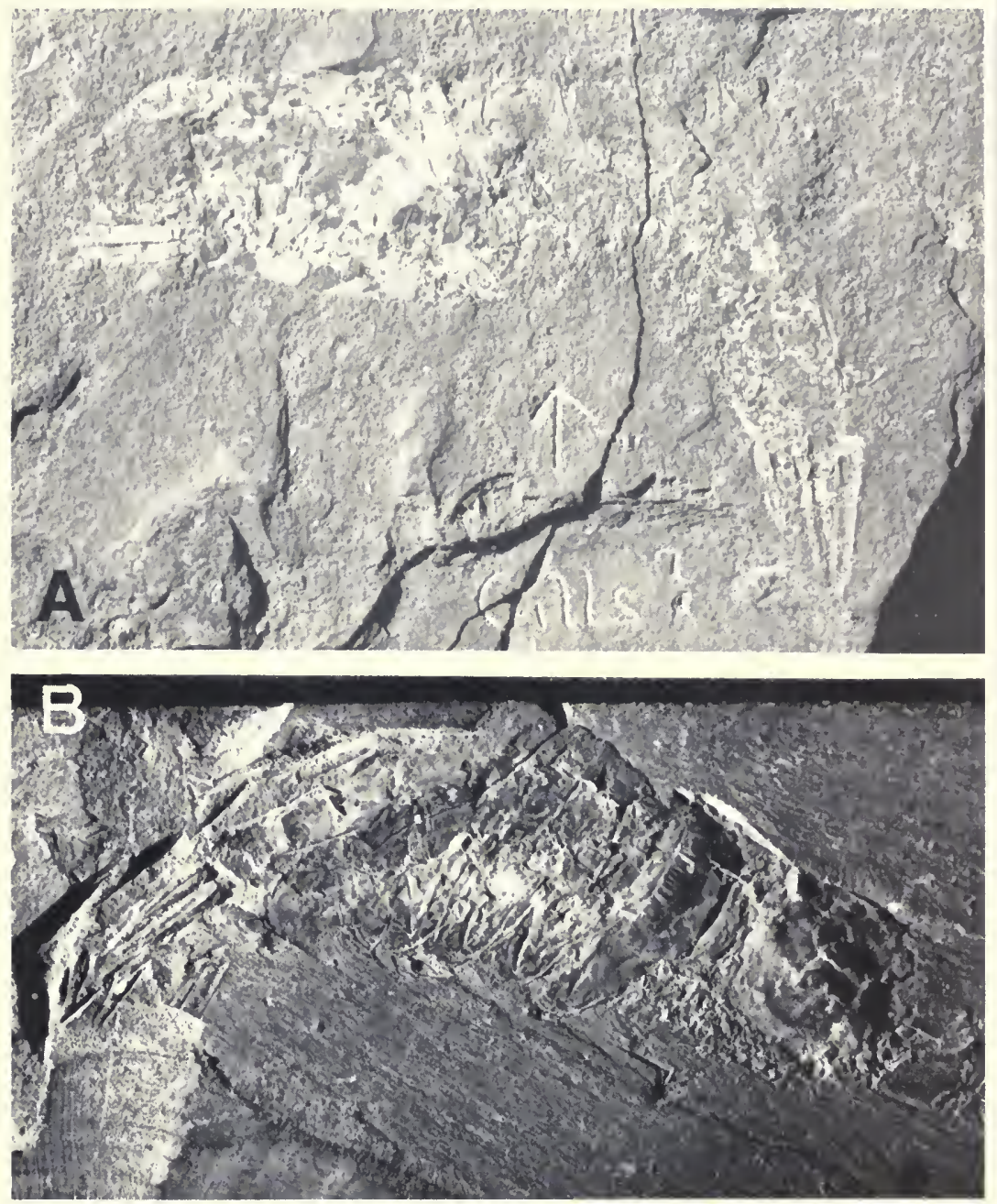

FIG. 26. Anthracophausia dunsiana Peach, 1908. A, GSE 5819, lectotype, $3.8 \times$. B, R 1887.25.1060, with well-preserved abdominal pleura, $1.8 \times$.

1969 Anthracophausia dunsiana Peach. Brooks, p. R342.

1969 Anthracophausia rhodesi (Peach). Brooks, p. R343.

1969 Anthracophausia couttsi (Peach). Brooks, p. R343.

? 1969 Anthracophausia magna (Peach). Brooks, R343.

? 1969 Anthracophausia hastata (Peach). Brooks, p. R343.

1969a Anthracophausia dunsiana Peach. Schram, p. 215, table 1. 1969 a Anthracophausia dunlopi (Peach). Schram, p. 215, table 1. 1969a Anthracophausia couttsi (Peach). Schram, p. 215, table 1. 1969a Anthracophausia tenuis (Peach). Schram, p. 215, table 1. 
1969a Anthracophausia rhodesi (Peach). Schram, p. 215, table 1.

? 1969a Anthracophausia magna (Peach). Schram, p. 215, table 1.

? 1969a Anthracophausia hastata (Peach). Schram, p. 215, table 1.

Lectotype (here designated).-GSE 5819 (fig. 26a); River Esk, Glencartholm, 11/2 miles below Langholm, Dumfriesshire; Glencartholm Volcanic Beds, Calciferous Sandstone Measures.

Diagnosis. - Abdominal pleura somewhat pointed ventrally. Telson with two lobe-like ridges on dorsum. Uropods blade-like. Inner margin of uropodal exopod with setae.

Description. - The carapace is rectangular in outline (GSE 5819, fig. 26a) with a large optic notch (GSE 5822, fig. 27). The posteroventral border of the carapace is somewhat attenuated and not greatly developed as a branchiostegal lobe. The rostrum (GSE 5819, 5822 ) is quite prominent and markedly falciform, developing a dorsal crest as it projects forward from the carapace. The antennules have been poorly preserved and only GSE 5819 has remnants of them. The antenna had a characteristically large and deeply grooved scaphocerite (GSE 5882, R 1887.25.1063).

The thoracopods have not been preserved, with the poor exception of GSL R1681, where they seem to be of the delicate variety associated with natant filter feeders.

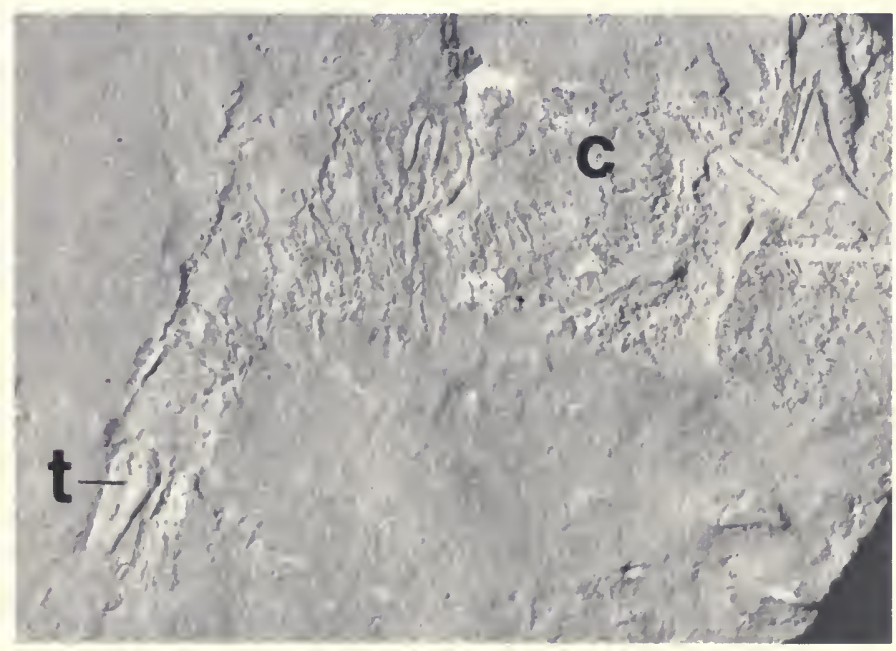

FIG. 27. Anthracophausia dunsiana Peach, 1908. GSE 5822, with ridges on the antennal peduncles, carapace $(c)$, telson $(t), 3.5 \times$. 
FIG. 28. Anthracophausia dunsiana Peach, 1908. GSE 5824, sixth pleomere (p) with telson (t) and uropod, $7 \times$.

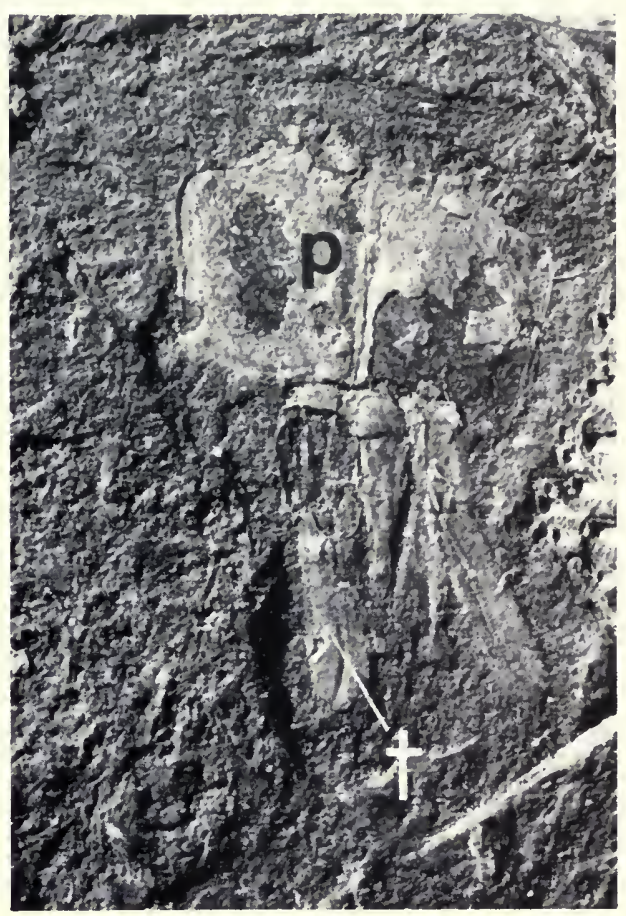

The first five pleomeres are all equal in length. The pleura of these segments are prominent and developed so as to point ventrad along the postero-ventral margin (GSE 5822). The sixth pleomere is greatly elongate ( $R$ 1887.25.1060A).

The telson has a very characteristic shape. It was developed with a pair of prominent lobe-like ridges along its dorsal surface (GSE 5824 , fig. 28). The distal end of the telson is seldom preserved but $R$ 1887.25.1060A (fig. 26b) seems to indicate it was pointed, and GSL R1683 and GSE 5824 imply the terminal tip may have been flanked by furca. The uropods are located somewhat ventral to the telson. It is common to have a tailfan preserved with only the uropods (a ventral preservation) or a telson (a dorsal preservation). $\mathrm{R}$ 1887.25.1031 is one of the few specimens which preserves the uropods and telson together, and displaying the uropodal exopod's lateral margin sclerotized and the median margin setiferous. The endopod is a membranous lobe.

Remarks. $-A$. dunsiana has been one of the most difficult species of Peach (1908) to revise. The thin cuticle of this form insures that 


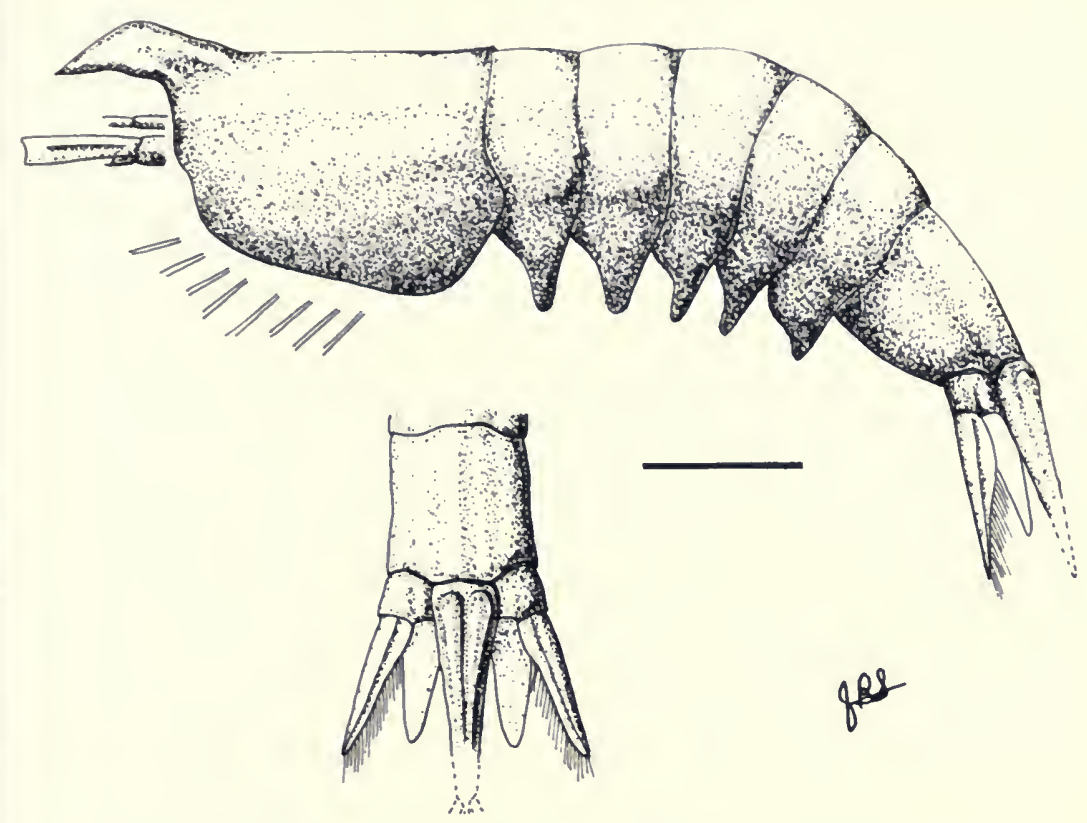

Fig. 29. Anthracophausia dunsiana Peach, 1908. Reconstruction, scale $5 \mathrm{~mm}$.

the range of preservational distortions and variations is at a maximum, much of the original syntypic suite proving to be Belotelson traquairi. Peach's subspecies $A$. dunsiana obesa turns out to be more characteristic of the species. The separately preserved tail fans were placed in a separate form genus, Palaemysis, which Brooks (1969) suppressed in favor of Anthracophausia. Peach gave different names to different grades of preservation within Palaemysis, with $P$. tenuis being the poorest in quality and $P$. couttsi being the best. Two aberrant preservational forms were placed in the genus Crangopsis, $C$. rhodesi and $C$. couttsi, which were actually better preserved in many regards than the type series of $A$. dunsiana.

Despite all the preservational variants, nothing has survived that would allow the determination of the affinities of $A$. dunsiana. It could be a euphausiacean, a mysidacean, neither of these (like Belotelson), or even (since the thoracopods are largely unknown) a decapod. In general form, however, it seems to be related to the North American form, Peachocaris strongi, and remains with that species in a separate family of the eocaridaceans (Schram, 1974a). 
Measurements are given in Table 10, a reconstruction in Figure 29.

Two species whose types have been lost may in fact be synonyms of A. dunsiana, viz., Crangopsis magna Peach, 1908, and Crangopsis hastata Peach, 1908. C. magna was based on a single specimen, GSE M2245e, from the Glencartholm Volcanic Beds of Eskdale, Dumfriesshire. It is difficult to decide what C. magna might be, based on the description and illustration alone. Peach repeatedly compares it with his species $C$. rhodesi which has been synonymized by me with Anthracophausia dunsiana, and there is certainly nothing in the illustration to contradict the possibility of such placement of C. magna as well. Peach's illustrations, however, can be misleading. The two specimens of $C$. hastata come from Chattlehope, Rede Water, Northumberland, locality 33. They demonstrate again Peach's fixation on tails. The supposed prominent terminal spike causes me to hesitate in placing this in A. dunsiana. Otherwise, with the bilobed aspect of the telson base and the known presence of $A$. dunsiana at this site, one might have synonymized $C$. hastata with $A$. dunsiana.

TABLE 10. Measurements in centimeters of some representative specimens of $A n$ -

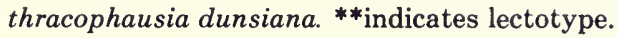

total

specimen carapace rostrum abdomen a5 a6 telson uropod

\begin{tabular}{|c|c|c|c|c|c|c|c|}
\hline GSE $5819^{* *}$ & 1.07 & .30 & & .40 & .58 & & \\
\hline GSE 5010 & 1.04 & & & & .50 & .70 & \\
\hline GSE 5822 & 1.14 & .32 & & & .50 & & \\
\hline R 1887.25 .1031 & & & 1.43 & & .34 & .51 & .56 \\
\hline R 1887.25 .1063 & 1.15 & & & & & .50 & .80 \\
\hline
\end{tabular}

$\overline{\mathrm{x}} \quad 1.10$

Family: Waterstonellidae nov.

Diagnosis.-Same as that of the genus.

Waterstonella gen. nov.

Type species. - Waterstonella grantonensis sp. nov. Granton shore, near Edinburgh; Wardie Shale, Oil Shale Group, Calciferous Sandstone Measures. 
Diagnosis. - Small nektonic to planktonic form. Body thin, cylindrical, and elongate. Carapace thin and transparent. Appendages short and setiferous. Antennule peduncles as long as thorax. Sixth pleomere and uropods as long as first five pleomeres.

Etymology. - The genus is named in honor of Dr. Charles Waterston, Keeper of Geology, Royal Scottish Museum.

Waterstonella grantonensis sp. nov. Figures 30, 31. Table 11.

1925 unnamed shrimp, Tait, p. 132, pl. 17.

Holotype.-GSE 13053 (fig. 30); Granton shore, near Edinburgh; Wardie Shale, Oil Shale Group, Calciferous Sandstone Measures.

Diagnosis.-Since there is only one species, the diagnosis is the same as that of the genus.

Etymology.-The name is a reference to the type locality of the form along Granton shore, Midlothian, Scotland.

Description.-The body is thin, elongate, and cylindrical. The length of the total outstretched animal can be roughly divided into four equal regions: the antennae, the cephalothorax, the first five pleomeres, and the sixth pleomere and tail.

The thin, flexible carapace (GSE 13051) covers the thorax completely, but is not fused to any of the segments. The first antenna is very long; the peduncle has three subequal segments, the most distal surmounted by two long flagella. The second antenna has a long

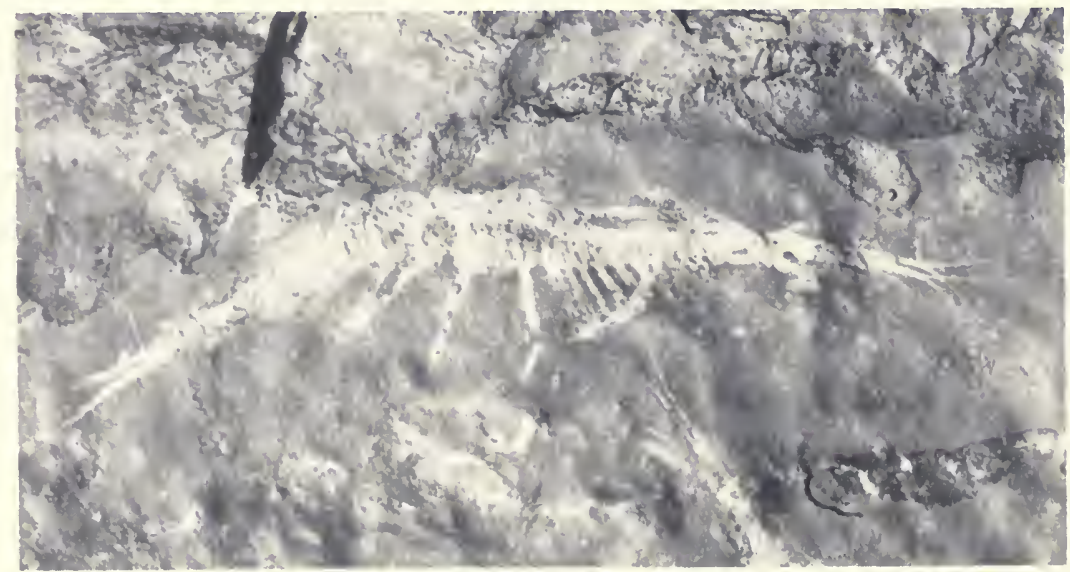

Fig. 30. Waterstonella grantonensis sp. nov. GSE 13053, holotype, $11 \times$. 
basal segment to which are attached an oval scaphocerite and a short flagellum (GSE 13052). There is a stalked compound eye (GSE 13053).

The eight thoracopods are all similar. The appendages proper are short, apparently biramous, and carry long, terminal setae.

The first five pleomeres are all equal in size and do not have welldeveloped pleura (GSE 13054). The pleopods are longer than the thoracopods and consist of a short protopod which bears elongate flap-like endopods and exopods which are tipped with setae as long as the flaps. The sixth pleomere is very long. The telson is long, thin,

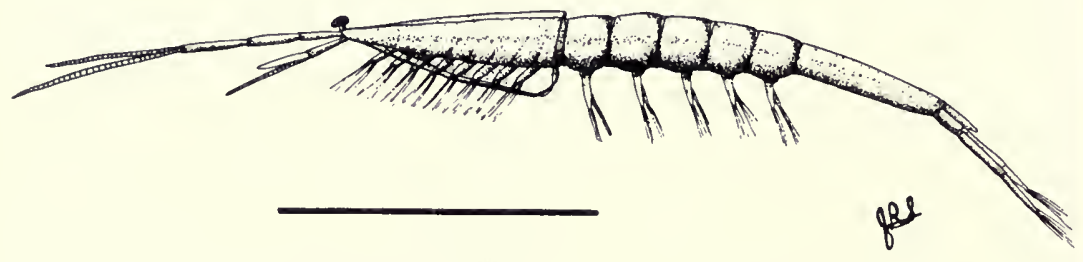

FIG. 31. Waterstonella grantonensis sp. nov. Reconstruction, scale $5 \mathrm{~mm}$.

and spatulate and is about half the size of the uropods. The uropodal exopods and endopods are composed of two long segments ( $R$ 1957.1.5129) which again appear to terminate in long setae (GSE 13055).

Remarks. - This shrimp is found from Lower Carboniferous localities from the south coast of the Firth of Forth west of Edinburgh. It always occurs in gregarious associations which may also occasionally include a few specimens of Crangopsis socialis.

The size and morphology of this animal seem to indicate a pelagic or nektonic habit. In morphology it resembles such extant specialized forms as the decapod Leucifer or the erythropine mysid Arachnomysis. All of these animals are characterized by small size, long and thin bodies, an elongation of the cephalon between the second antenna and the first thoracopod, and highly setiferous appendages.

The schizopodous limbs and unattached carapace on Waterstonella indicate a mysidacean affinity. But there is no indication of any kind of brood pouch on any of the individuals seen. Lack of oöstegites on a fossil would not be conclusive evidence against a possible relationship. The great delicacy of such structures would tend to act against their being preserved, and oöstegites would only be present during breeding. It is possible that $W$. grantonensis did not have a brood pouch, i.e., reproduced via some other means. It 
TABLE 11. Statistical data on some representative individuals of Waterstonella grantonensis. Measurements in centimeters. Individuals occur in dense associations on shale slabs; animals selected for measurement at random.

$\begin{array}{lccc} & \mathrm{n} & \text { range } & \overline{\mathrm{x}} \\ \text { cephalothorax } & 11 & .25 \cdot .75 & .39 \\ \text { abdomen (- telson) } & 10 & .52-1.34 & .77 \\ \text { carapace } & 3 & .25 \cdot .56 & .38\end{array}$

seems prudent to place Waterstonella in a separate family within the Eocaridacea.

Some statistics on a representative array of individuals is presented in Table 11, a reconstruction in Figure 31.

\section{Superorder: Peracarida Calman, 1904}

Order: Mysidacea Boas, 1883

Suborder: Pygocephalomorpha Beurlen, 1930

Family: Tealliocarididae Brooks, 1962b

Tealliocaris Peach, 1908

Type species.-Anthrapalaemon woodwardi (Etheridge), 1877. Cheese Bay near Gullane, East Lothian; Wardie Shale, Oil Shale Group, Calciferous Sandstone Series.

Diagnosis.-Antero-lateral corner of carapace without prominent spine. Carapace margins with prominent doublure. Carapace with hepatic spines, cervical grooves meeting in mid-dorsal line. Abdomen as large as cephalothorax. Pleopods simple biramous flaps. Uropod exopod with diaresis. Margins of tail fan setose. Telson with one large pair of caudal furca.

Tealliocaris woodwardi (Etheridge), 1877. Figures 32-34. Table 12.

\footnotetext{
v*. 1877 Anthrapalaemon woodwardi Etheridge, p. 863, pl. 27.

v. 1879 Anthrapalaemon woodwardi Etheridge. Etheridge, p. 468, pl. 23, figs. 4-9.

v. 1908 Tealliocaris loudenensis Peach, p. 9, pl. 1, figs. 1-7.

v. 1908 Tealliocaris woodwardi (Etheridge). Peach, p. 18, pl. 2, figs. 1-6.

v. 1908 Tealliocaris tarrasiana Peach, p. 26, pl. 3, figs. 13-16.

1911 Tealliocaris loudenensis Peach. Woodward, p. 363.

1911 Tealliocaris woodwardi (Etheridge). Woodward, p. 363.
} 
FIG. 32. Tealliocaris woodwardi (Etheridge) 1877. A, GSE 5930, with papillose surface on the cuticle, $3.9 \times$; B, P 32056 , arrow pointing to setiferous pleopods, $4.8 \times$.
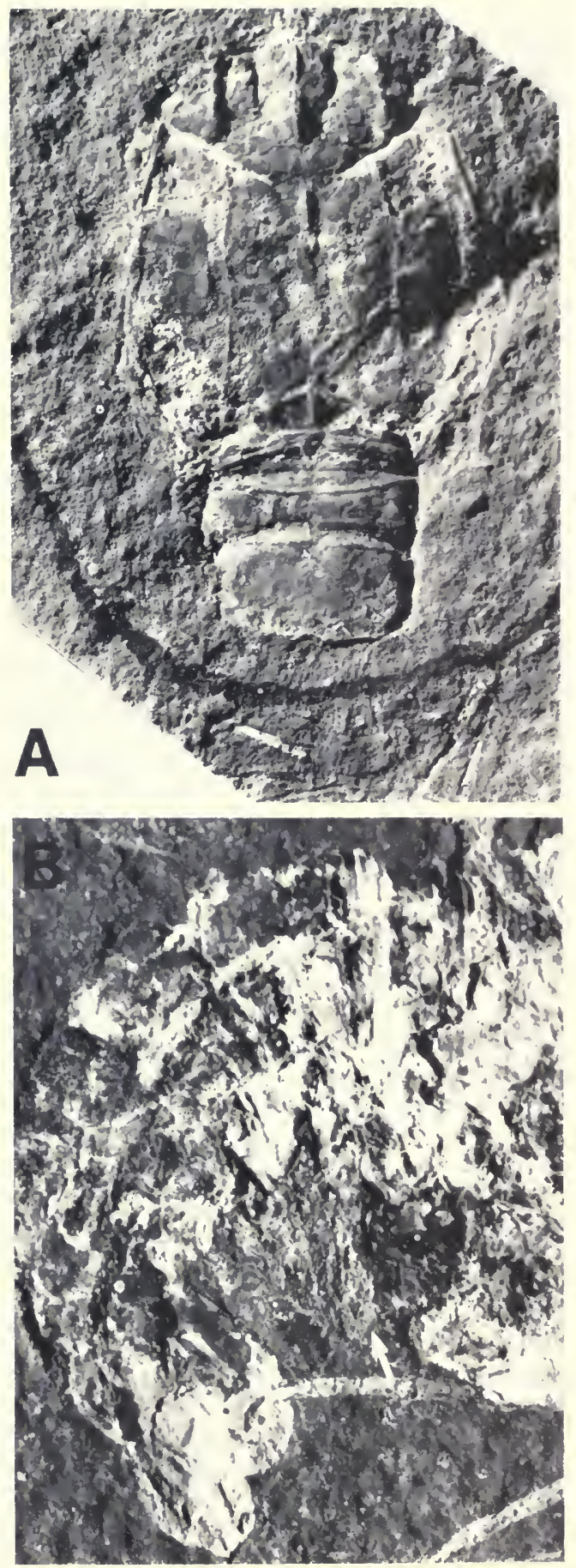


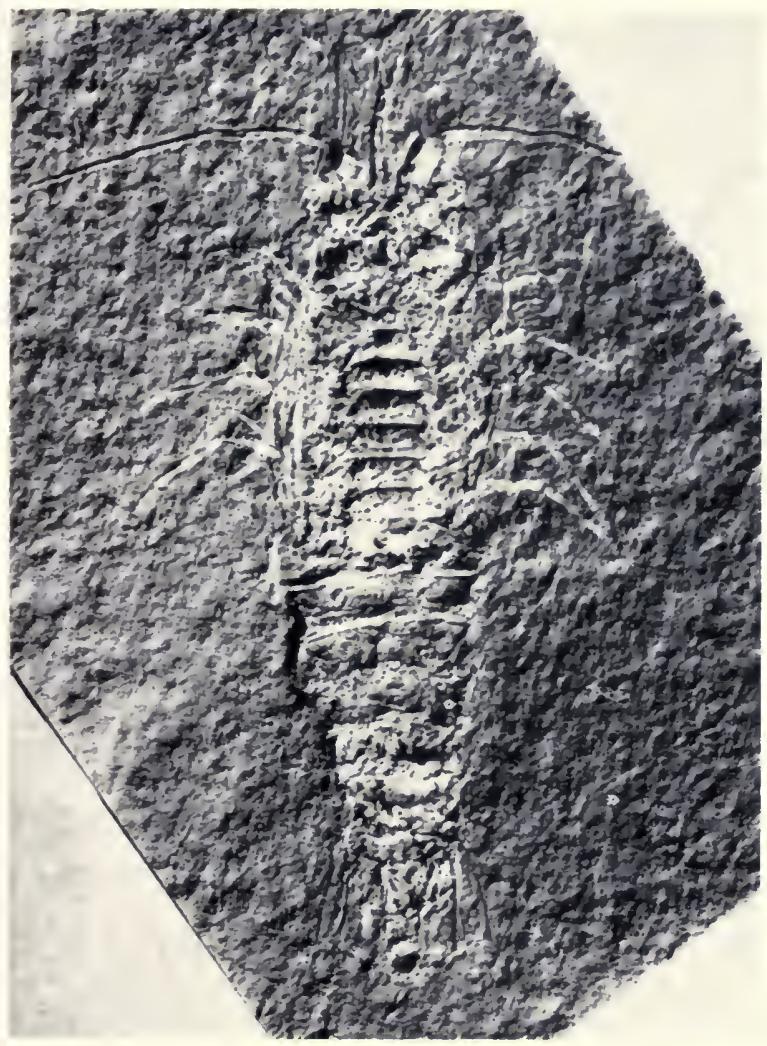

FIg. 33. Tealliocaris woodwardi (Etheridge), 1877. GSE 5931, whole animal with ventral preservation of thorax and thoracopods, $2.3 \times$.

1911 Tealliocaris woodwardi var. Peach. Woodward, p. 363.

1911 Tealliocaris tarrasiana Peach. Woodward, p. 363.

1962b Tealliocaris loudenensis Peach. Brooks, p. 288, pl. 7, figs. a, c.

1969 Tealliocaris loudenensis Peach. Brooks, p. R344, figs. 159, 1a, 1 b.

1969 Tealliocaris loudenensis Peach. Schram, p. 216, table 1.

1969a Tealliocaris woodwardi (Etheridge). Schram, p. 216, table 1.

1969 a Tealliocaris tarrasiana Peach. Schram, p. 216, table 1.

Lectotype (here designated).-GSE 5950, Cheese Bay, near Gullane, East Lothian; Wardie Shale, Calciferous Sandstone Measures.

Diagnosis.-Since there is only one species recognized, the diagnosis is the same as that of the genus.

Description.-The cuticle is moderately sclerotized with the dorsal surfaces decorated with fine papillations (GSE 5930, fig. 32a). The rostrum is long, extending to the distal end of the first antennal peduncle. The gastric spines are only slightly developed (GSE $5930 \mathrm{~b})$. The carapace is marked with cervical grooves which meet at 

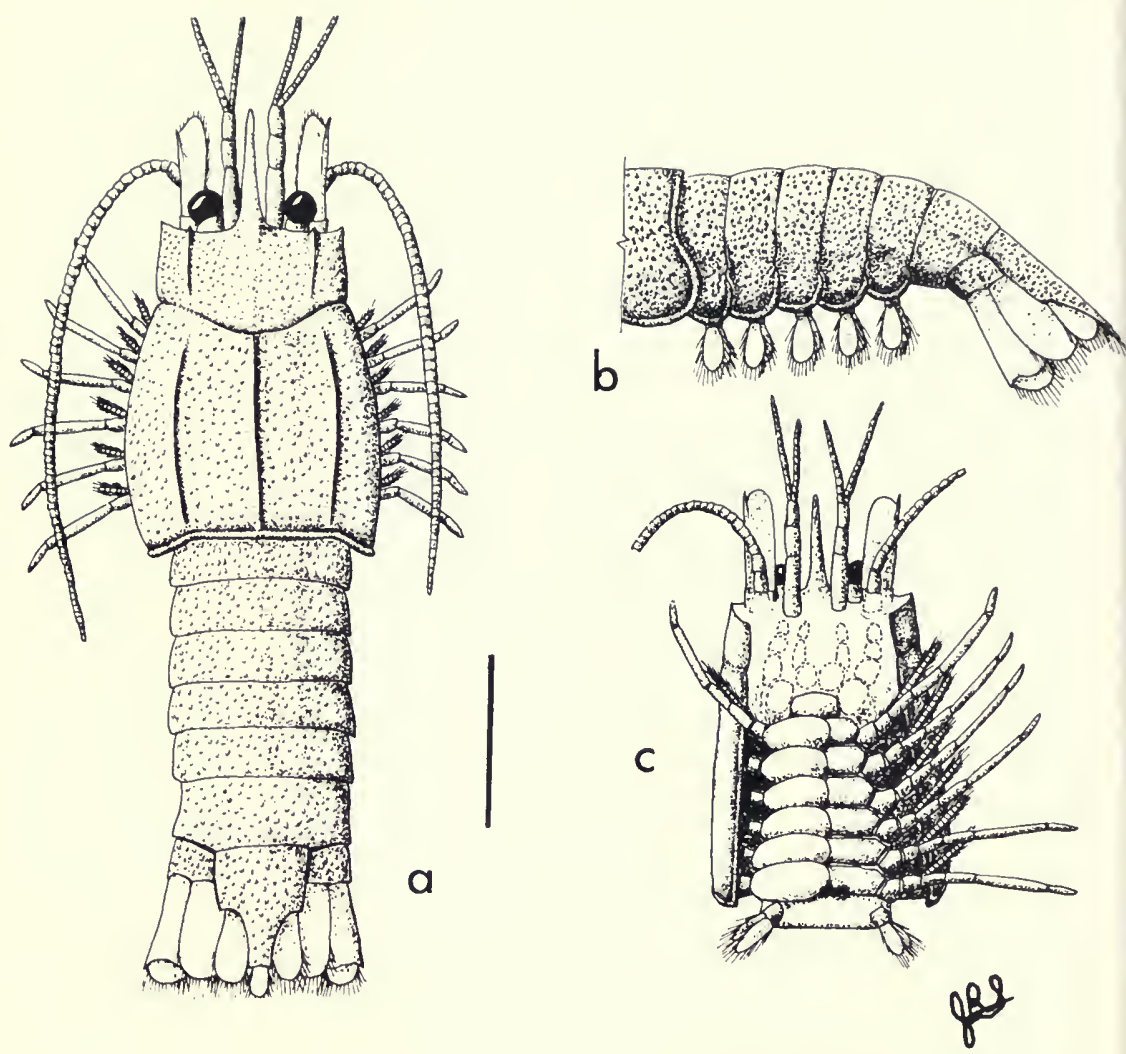

FIG. 34. Tealliocaris woodwardi (Etheridge), 1877. Reconstruction, scale $5 \mathrm{~mm}$. A, dorsal view; $\mathbf{B}$, lateral view of abdomen; $\mathbf{C}$, ventral view of a female with oöstegites in position on the left and removed on the right side to display leg bases.

the dorsal midline and five longitudinal ridges which extend from the cervical groove to the posterior doublure of the carapace. GSL Za2973 has a large, stalked eye. The first antennal peduncle has three segments (GSE 5930b): the most proximal is half the length of the whole peduncle, the distal two are subequal. The second antenna has a large oval scaphocerite.

The thoracopods have the annulate exopod (GSE 5931, fig. 33) arising from the basis, and an endopod composed of four segments. The ischiomerus and carpus are subequal, the propodus is about half again as long as either of the first two segments, and the dactylus is short. GSE 5936 clearly preserves the brood pouch. GSE 5939 has the maxilliped palps poorly preserved. The thoracic sternites have a median process and the sternite field of the pereiopods 
TABLE 12. Measurements in centimeters of some representative specimens of Tealliocaris woodwardi. ** indicates lectotype.

\begin{tabular}{|c|c|c|c|c|}
\hline specimen & carapace & $\begin{array}{c}\text { total } \\
\text { abdomen }\end{array}$ & telson & uropod \\
\hline GSE $5950^{* *}$ & & .56 & .30 & \\
\hline GSE 5931 & .96 & .70 & .50 & .43 \\
\hline GSE 5932 & 1.09 & 1.30 & & \\
\hline GSE 5933 & & .78 & .31 & \\
\hline GSE 5938 & & .96 & .50 & .47 \\
\hline GSE 5939 & 1.10 & & & \\
\hline GSE 5951 & 1.06 & .97 & & \\
\hline GSE 5952 & .80 & .60 & & \\
\hline GSE 9651 & & 1.10 & .62 & \\
\hline I 7417 & 1.0 & 1.12 & .40 & \\
\hline In 43918 & .80 & .70 & .40 & \\
\hline In 43940 & .43 & .40 & .20 & \\
\hline In 43942 & 1.15 & .84 & .42 & \\
\hline In 43965 & .97 & 1.10 & .53 & \\
\hline$\overline{\mathbf{x}}$ & .94 & .86 & .42 & \\
\hline
\end{tabular}

is not quite as triangular as most pygocephalomorphs (Schram, 1974a).

The abdominal pleura are gently rounded. One exciting new find is the observation of pleopods on three specimens of this species: $\mathrm{E}$ 19901, GSL Za2937, and P 32056 (fig. 32b). This is the first recording of pygocephalomorph pleopods. They are biramous, flap-like, setiferous appendages. The telson is somewhat triangular with prominent caudal lobes and a lobate caudal spine. The uropods are flat and lobate with a gently curving diaresis on the exopod (GSE 5938). 
Remarks. - The description above substantially agrees with the reconstructions offered by Brooks $(1962,1969)$ with the addition of newly observed structures like eyes and pleopods.

No objective difference between $T$. woodwardi and $T$. loudenensis can be detected. The T. woodwardi sensu Peach happens to be toward the smaller end of the range of variation, but broadly overlaps with that of $T$. loudenensis sensu Peach. T. tarrassiana is merely a poorly preserved variant.

Measurements of representative specimens are given in Table 12, a reconstruction in Figure 34.

Pseudogalathea Peach, 1883

Type species.-Anthrapalaemon macconochiei Etheridge, 1879. Tweeden Burn, near Liddel Water; Cementstone Group, Calciferous Sandstone Measures.

Diagnosis.-Antero-lateral corner of carapace with short, round processes. Postero-lateral corner of carapace pointed. Carapace with median and lateral longitudinal ridges and with lateral and posterior margins greatly thickened. Abdomen small. Body dorso-ventrally flattened.

Pseudogalathea macconochiei (Etheridge), 1879. Figures 35, 36. Table 13.

\footnotetext{
v*. 1879 Anthrapalaemon macconochiei Etheridge, p. 471, pl. 23, fig. 10.

v. 1882 Anthrapalaemon macconochiei Etheridge. Peach, p. 82, pl. 8, figs. 6-6d.

v. 1882 Anthrapalaemon ornatissimus Peach, p. 83, pl. 8, fig. 7 .

v. 1883 Pseudogalathea rotunda Peach, p. 514, pl. 28, figs. 6-6a.

1883 Pseudogalathea macconochiei (Etheridge). Peach, p. 514.

v. 1883 Pseudogalathea ornatissima (Peach). Peach, p. 515, pl. 28, figs. 7-7b.

1903 Pseudogalathea macconochiei (Etheridge). Peach and Horne, p. 846.

v. 1908 Pseudogalathea macconochiei (Etheridge). Peach, p. 28, pl. 3, figs. 19-22.

v. 1908 Pseudogalathea rotunda Peach. Peach, p. 28, pl. 3, figs. 23, 24.

v. 1908 Pseudogalathea ornatissima (Peach). Peach, p. 29, pl. 3, figs. 25-29.

1911 Pseudogalathea macconochiei (Etheridge). Woodward, p. 363.

1911 Pseudogalathea rotunda Peach. Woodward, p. 263.

1911 Pseudogalathea ornatissima (Peach). Woodward, p. 363.

1969 Pseudogalathea rotunda Peach. Brooks, p. R344.

1969a Pseudogalathea macconochiei (Etheridge). Schram, p. 216, table 1.

1969a Pseudogalathea rotunda Peach. Schram, p. 216, table 1.

1969 a Pseudogalathea ornatissima (Peach). Schram, p. 216, table 1.
}

Lectotype (here designated).-GSE 5911 (fig. 35); Tweeden Burn, near junction with Liddel Water, one-half mile below Newcastleton, 


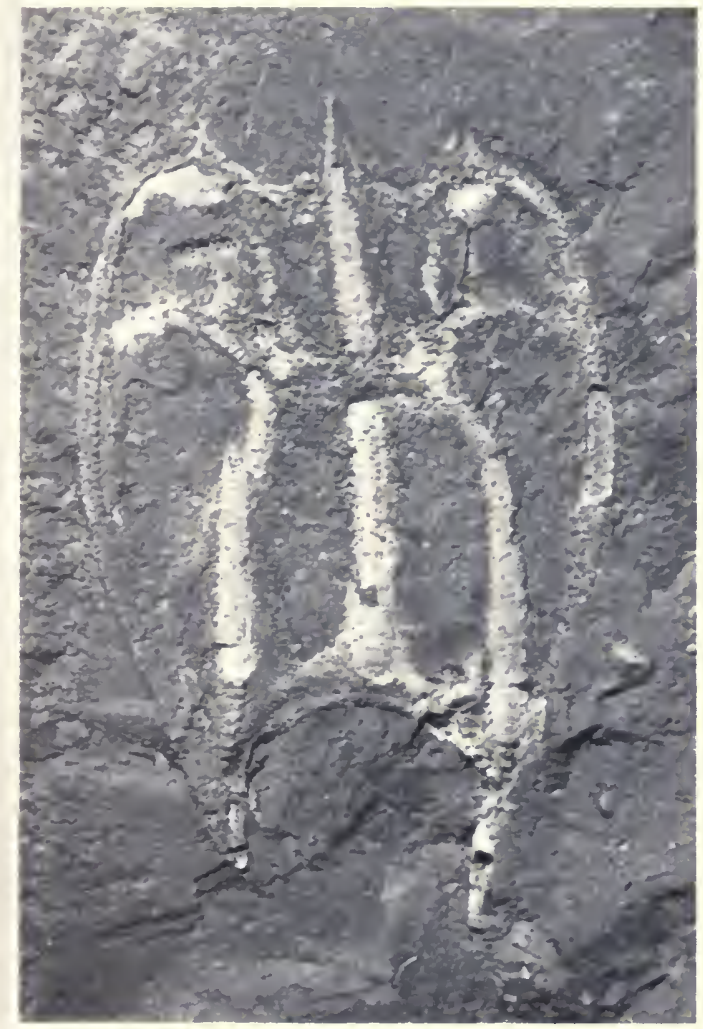

Fig. 35. Pseudogalathea macconochiei (Etheridge), 1877. GSE 5911 , lectotype, $3.9 \times$.

Roxburghshire; Cementstone Group, Calciferous Sandstone Measures.

Diagnosis.-Since there is but one species, the diagnosis is the same as that of the genus.

Description.-The highly sclerotized nature of the exoskeleton of $P$. macconochiei combined with the characteristic ornamentation of the carapace and flat body make this the most distinctive of pygocephalomorphs. The carapace is flat, somewhat oval in outline, and with a short rostrum (GSE 5908). The rostrum is continuous with a mid-dorsal keel which extends uninterrupted to the posterior margin of the carapace except for a break at the cervical grooves which meet at the midline. A pair of lateral ridges extend posteriad from the cervical grooves and end as the large postero-lateral processes of the carapace. There is a very small antero-lateral spine just laterad to the optic notch. The lateral margins of the carapace are broadly 


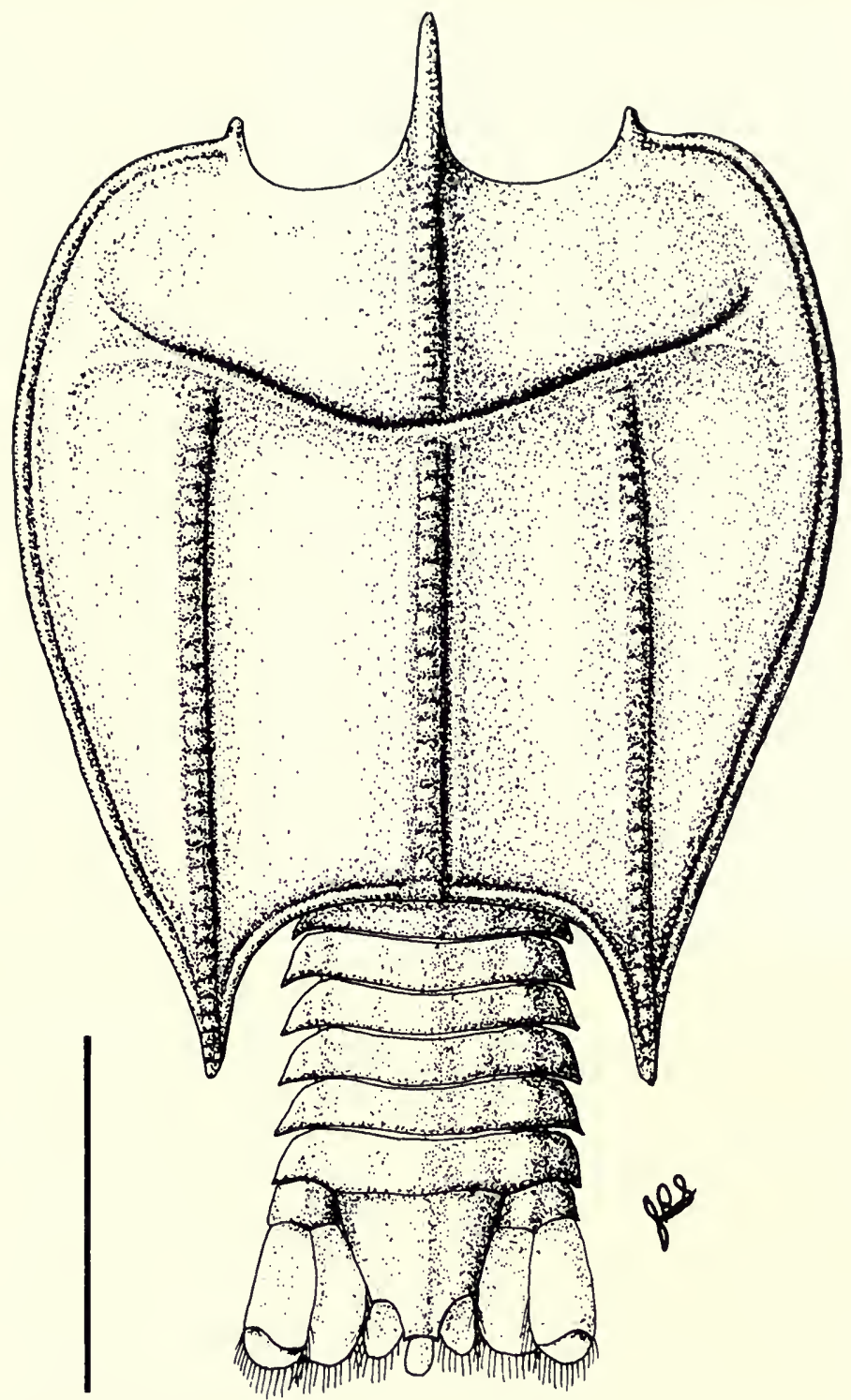

FIG. 36. Pseudogalathea macconochiei (Etheridge), 1877. Reconstruction, scale 5 $\mathrm{mm}$. 
TABLE 13. Measurements in centimeters of some representative specimens of Pseudogalathea macconochiei. ** indicates lectotype. carapace

specimen

GSE 5911**

GSE 5907

GSE 5908

GSE 5909

GSE M4277-6e

GSL R1671

R 1957.1.5073

R 1957.1.5076

E 13478

E 13479

E 13480

E 13481

E 13482

E 13484

A 1967

A 1968

A 1969

A 1971

A 1972

A 1974

A 1975

A 1977

$\overline{\mathbf{x}}$

.70

.64

.77

\section{midline lateral margin}

1.34

1.10

1.40

1.53

1.14

2.35

1.05

2.41

3.12

1.67

.68

.30

abdomen

.56

.24 telson

$1.12 \quad 1.63$

$\begin{array}{ll}.48 & .68\end{array}$

.90

$.70 \quad .96$

$1.30 \quad 1.92$

$1.15 \quad 1.70$

$\begin{array}{ll}.60 & .76\end{array}$

$\begin{array}{ll}.89 & 1.17\end{array}$

1.10

$1.08 \quad 1.47$

$.90 \quad 1.20$

$1.03 \quad 1.47$

$.89 \quad 1.22$

$1.12 \quad 1.50$

$1.02 \quad 1.48$

.76 
rounded and marked with a thick ridge. The anterior and posterior margins of the carapace are also thickened.

Little can be determined about the ventral anatomy of the thorax, except that from what poor specimens are at hand it appears to conform to a general pygocephalomorph plan, i.e., wide sternites with legs directed laterally.

The abdomen is relatively short and narrow compared to the carapace (GSE 5914). The telson is subrectangular with a lobate caudal spine. Small caudal furca are present. The exopod of the uropod has a sigmoid diaresis (GSE 5907). The lobes of the tail fan are decorated with setae.

Remarks. - The three different species attributed to Pseudogalathea are basically three different preservational variants. $P$. macconochiei specimens are typically larger, well-preserved carapaces; $P$. ornatissima are usually poorly preserved ventral sides, somewhat intermediate in size; while the $P$. rotund $a$ are the smallest carapaces.

Some representative measurements of $P$. macconochiei are offered in Table 13, a reconstruction in Figure 36.

Family: Pygocephalidae Brooks, 1962b

Pygocephalus Huxley, 1857

(=Anthrapalaemon Salter, 1861b; Palaeocarabus Salter, 1861b; Diplostylus Salter, 1863a; NecroscillaWoodward, 1879).

Type species.-Pygocephalus cooperi Huxley, 1857. Medlock Park Bridge, Ashton-under-Lyne, Lancashire; Lower Coal Measures, Upper Communis Zone.

Diagnosis.-Carapace without hepatic spines. Females with oöstegites and seminal receptacle. Telson narrows posteriorly in two abrupt steps with furcal lobes at each narrowing.

Remarks. - This genus has been the subject of great taxonomic confusion. In addition to the British species, there is continental and Canadian material. Only British material is dealt with here, but since the British species have priority on any other material, revision here can eventually be applied to other specimens.

Part of the confusion on species number and identity in the genus Pygocephalus arose from the fact that two holotypes, GSL 5439899, (fig. 40) for Prestwitch (1840), Apus dubius; and R 1974.14 (fig. 43) for Salter (1861b), Anthrapalaemon grossarti, are two extremes of bad preservation. GSL 54398-99 is a large fragmentary concre- 
tionary specimen, having a small number of surface papillations. $\mathrm{R}$ 1974.14 is a carbonized film on a black shale, and so badly eroded as to have obscured the original papillary ornament and established a secondary one of diagenetic pitting. The material of Salter and Peach identified as $A$. russelianus is closer to the norm of $P$. dubius in terms of preservation and ornament.

Different genera have been erected for different parts of the body. Pygocephalus was used by the old workers to refer to the ventral thorax; Anthrapalaemon, the carapace; Necroscilla, the abdomen; and Diplostylus, a well-preserved tail fan. Combine this with the numerous variations of form species placed in each of these genera, and we arrive at some idea of the confusion.

It has only been possible to sort out the confusion by examining as many specimens of this genus as could be located. $P$. cooperi is typically preserved with the abdomen flexed. Specimen In 18580 associates that distinctive tail fan with the smooth unornamented carapace. $P$. dubius is allied with this genus on the basis of specimens like GSL 30281 which associates the characteristic tail fan with the ornamented carapace. The placing of specimens stratigraphically and geographically has assisted in reconstructing species, particularly in terms of being able to associate separate parts to obtain an idea of an intact animal.

\section{Pygocephalus cooperi Huxley, 1857. Figures 37-39a, b. Table 14.}

v*. 1857 Pygocephalus cooperi Huxley, p. 363, pl. 13, figs. 1, 3.

1867 Pygocephalus cooperi Huxley. Woodward, p. 242, pl. 3, figs. 1, 2.

v. 1879 Necroscilla wilsoni Woodward, p. 551, pl. 26, fig. 3 .

v. 1899 Anthrapalaemon glaber Jones and Woodward, p. 393, pl. 15, fig. 5 .

v. 1905 Anthrapalaemon serratus Woodward, p. 438, fig. 1.

v. 1905 Anthrapalaemon woodwardi Etheridge. Woodward, p. 439, fig. 2.

1905 Anthrapalaemon traquairi ? Peach. Woodward, p. 440.

1907 Pygocephalus cooperi ? Huxley. Woodward, p. 405, pl. 18, fig. 1.

1907 Pygocephalus cooperi Huxley. Woodward, p. 405, pl. 18, figs. 1-6.

v. 1907 Pygocephalus (Anthrapalaemon) parkeri Woodward, p. 407, fig. 2.

? 1911 Anthrapalaemon grossarti holti Woodward, p. 365, fig. 1.

1914 Pygocephalus cooperi Huxley. Peach, p. 147, pl. 4, figs. 10, 11.

1930 Pygocephalus cooperi Huxley. Beurlen, p. 442, fig. 61.

1948 Anthrapalaemon sp. Edwards and Stubblefield, p. 215.

v. 1951 Pygocephalus (Anthrapalaemon ?) parkeri Woodward. Van der Heide, p. 33.

1951 Anthrapalaemon glaber Jones and Woodward. Van der Heide, p. 33.

? 1951 Anthrapalaemon holti (Woodward). Van der Heide, p. 34.

? 1957 Anthrapalaemon dubius (Prestwich). Rhodes and Wilson, p. 1163.

1962a Pygocephalus cooperi Huxley. Brooks, p. 195. 


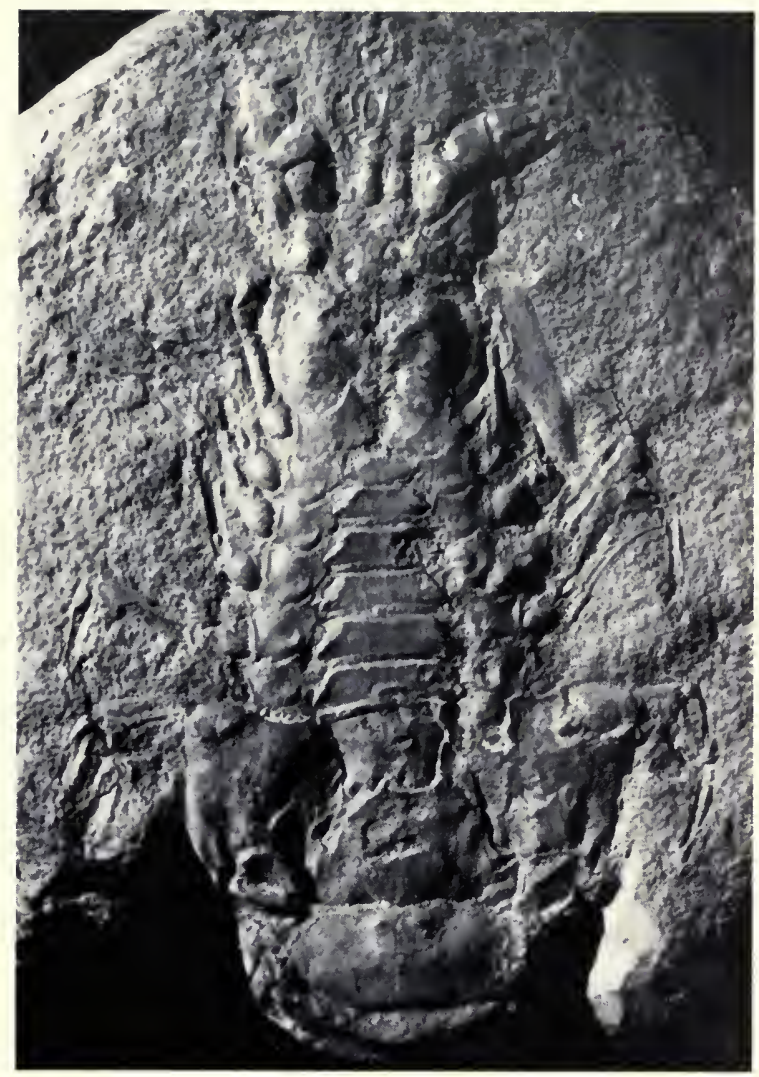

FIG. 37. Pygocephalus cooperi Huxley, 1857. L 10221, holotype, ventral thorax with portion of flexed abdomen, $1.3 \times$.

1969 Pygocephalus cooperi Huxley. Brooks, p. R344.

1969 Pygocephalus dubius (Prestwich). Brooks, figs. 161, 1a-1b.

? 1969a Pygocephalus holti (Woodward). Schram, p. 219, table 1.

Holotype.-L 10221 (fig. 37); Medlock Park Bridge, Ashtonunder-Lyne, Lancashire; Upper Communis Zone, Lower Coal Measures.

Diagnosis.-Cuticle smooth. Rostrum falciform. Carapace with six or seven branchiostegal teeth on anterior margin.

Description. - The surface of the carapace is smooth and not adorned with any ornamentation (In 18580). The rostrum is long and extremely falciform (I 13948, fig. 38; L 6966) and will sometimes be found broken off and the anterior margin of the carapace appear- 


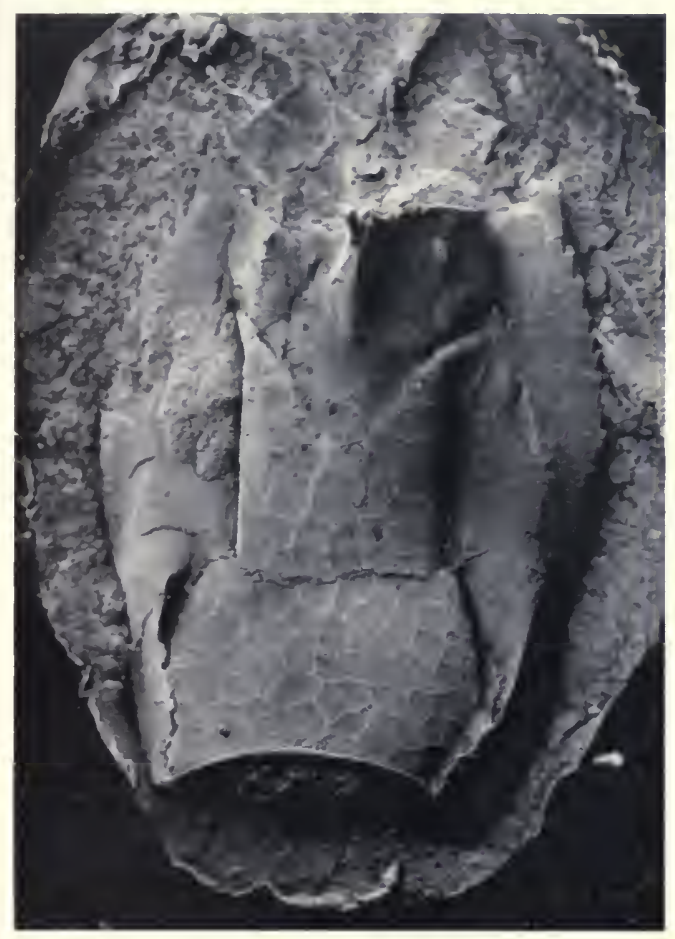

Fig. 38. Pygocephalus cooperi Huxley, 1857. I 13948, latex mold, with distal part of falciform rostrum missing, note anterior restriction of branchiostegal serrations, $2.8 \times$.

ing as if there were no rostrum (GSL 30248-85, In 18580). The antero-lateral spine is moderately developed and there are typically six or seven branchiostegal serrations on the anterior half of the lateral margin of the carapace. The carapace has a slight doublure on the posterior margin.

The peduncle of the first antenna is slightly longer than the rostrum. The most proximal of the three segments is about half the total length of the peduncle. The distal two segments are subequal. The peduncle of the second antenna has three subequal segments with a large oval scaphocerite. Eyes have not been noted on any of the specimens at hand.

The oöstegites have been figured many times in the literature and are preserved on many specimens (e.g., GSL 23453, 23456). The thoracic sternite field is a little different than most pygocephalomorphs. The eighth sternite is almost twice as long as any of the others (L 10221, fig. 37; GSE 26138-9), and the sternite of the second thoracomere is quite wide (though the associated thoracopod appears tu be still functioning as a maxilliped). The coxa of the pereio- 
TABLE 14. Measurements in centimeters of some representative specimens of Pygocephalus cooperi.

specimen

GSE 4983

A 2012

A 2014

A 2015

A 2143

GSL 23458

GSL 30284

GSL AT 4990

GSL Za 2954

I 992

I 13948

In 18580

In 41511

In 61404

L 6964

L 6966

R 1911.6.13

$\overline{\mathbf{x}}$ carapace

.55

1.86

1.20
.47

.55

.80

1.84

1.42

1.30

.66

2.15

1.70

.57

1.27

1.30

.58

1.24

1.48

$>.48$

1.0

telson

pods is large and wide, the basis is small. The ischiomerus, carpus, and propodus are subequal, while the dactylus is short. The annulate exopod is attached to the basis ( $\mathrm{L}$ 10221). The maxillipeds have large gnathobases and palps with apparently three or four segments. Several specimens, among them L 10221, show that the carapace developed a slight ventral shelf on its underside to partially floor the branchiostegal chamber. 


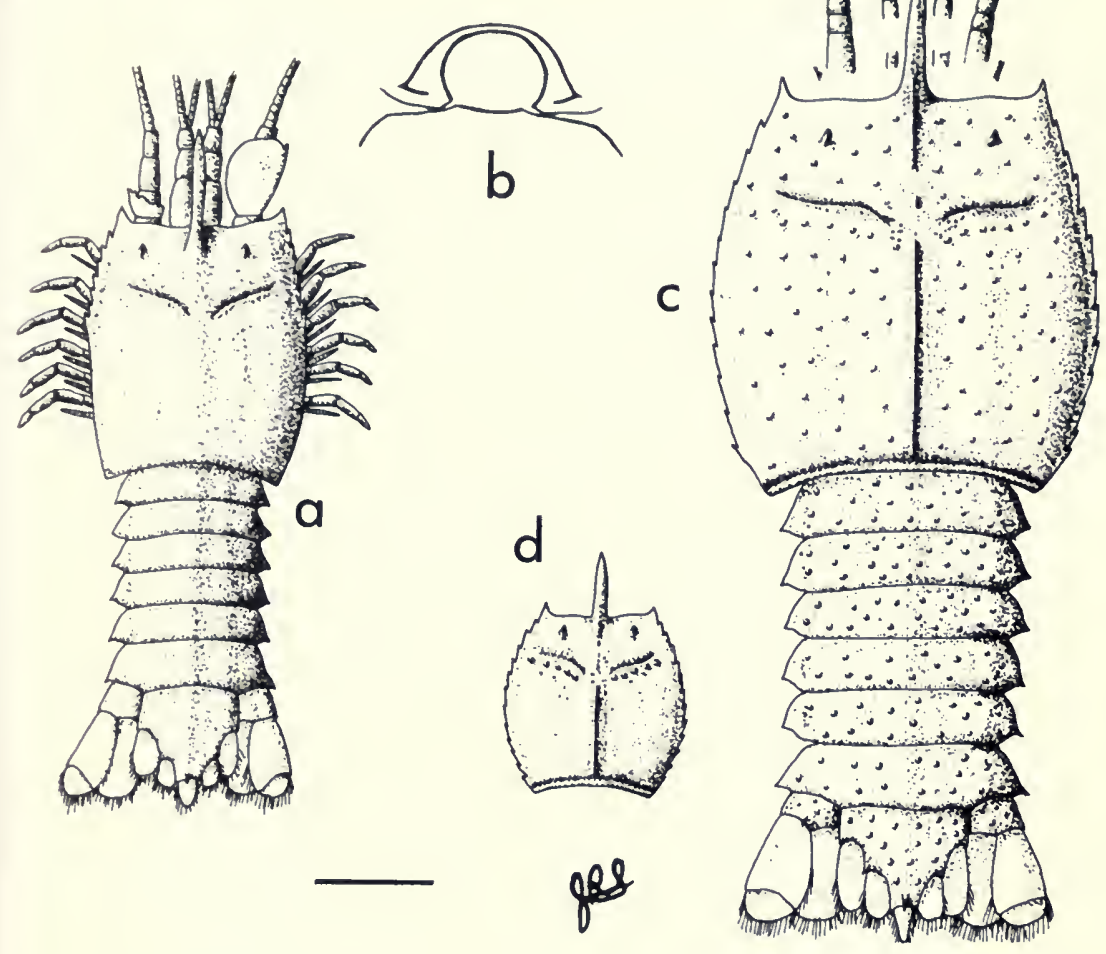

FIG. 39. Reconstructions. A, Pygocephalus cooperi Huxley, 1857; B, schematic section through $P$. cooperi thorax to show ventral shelf of carapace which partially floors the branchiostegal chamber; C, $P$. dubius (Prestwich) 1840; D, P. dubius carapace of the small, undecorated variant of this species.

The abdomen is so frequently preserved in a flexed condition (more so than in any other non-notocarid forms) that it would almost appear that this was the normal position for it. There are a number of specimens, however (L 6966, In 18580), which preserved the abdomen extended. The pleura of the pleomeres are developed and directed ventrally as a pointed pleural process.

The tail fan is very distinctive. The telson narrows posteriorly in two distinct steps. Each step has a furcal lobe associated with it, the anterior pair being larger than the second pair (I 992, L 8195). (The lobes are quite distinct and caused Salter (1863a) to describe a Pygocephalus tail from Canada under the name Diplostylus.) The caudal spine is pointed and partly overlain by a small middorsal process of the telson. The exopod of the uropod has a sigmoid diaresis. 
Measurements are given in Table 14, a reconstruction in Figure 39.

It has not been possible to definitively place Anthrapalaemon holti (Woodward) 1911. The type is lost. Van der Heide (1951) recognized this as a separate species. Rhodes and Wilson (1957) synonymized it with $P$. dubius, though they never saw the specimen and worked from the literature (personal communication). From what I can gather of its morphology from the description (size, lack of carapace ornament, seven branchiostegal spines on the anterior margin of the carapace, its locality, and stratigraphic position), $A$. holti is most likely synonymous with $P$. cooperi.

Pygocephalus dubius (Prestwich), 1840. Figures 39c, d-43. Tables $15,16$.

v*. 1840 Apus dubius Prestwich, p. 491, fig. 9.

v. 1861 b Anthrapalaemon grossarti Salter, p. 530, figs. 1-4.

1861b Anthrapalaemon sp. Salter, p. 530, fig. 5.

1861b Anthrapalaemon (Palaeocarabus) dubius (Prestwich). Salter, p. 532, figs. $6,7$.

v. 1863 b Palaeocarabus russelianus Salter, p. 519, figs. 1 \& 2 .

1867 Anthrapalaemon grossarti Salter. Woodward, p. 246, figs. 5-7.

1867 Anthrapalaemon russelianus (Salter), Woodward, p. 246.

v. 1908 Anthrapalaemon russelianus (Salter) Peach, p. 30, pl. 4, figs. 1-6.

v. 1908 Anthrapalaemon russelianus spinulosus Peach, p. 36, pl. 4, fig. 7.

1911 Anthrapalaemon grossarti Salter. Woodward, p. 363.

1911 Anthrapalaemon grossarti spinulosus Peach. Woodward, p. 363.

1930 Anthrapalaemon russelianus (Salter). Dix, p. 103, fig. 1.

1951 Anthrapalaemon dubius (Prestwich). Van der Heide, p. 34.

1951 Anthrapalaemon grossarti Salter. Van der Heide, p. 34.

1957 Anthrapalaemon dubius (Prestwich). Rhodes and Wilson, p. 1159, figs. 1-2.

1962b Pygocephalus dubius (Prestwich). Brooks, p. 194, pl. 6, figs. a-c.

1969 Pygocephalus dubius (Prestwich). Brooks, p. R344, figs. 160, 1c, 1d.

1969a Pygocephalus dubius (Prestwich). Schram, p. 219, table 1.

1969a Pygocephalus grossarti (Salter). Schram, p. 219, table 1.

Holotype.-GSL 54398-9 (fig. 40); Coalbrookdale, Shropshire; Whiteflat Ironstone, Middle Coal Measures, Modiolaris Zone.

Diagnosis.-Cuticle papillose. Rostrum not markedly falciform. Carapace with average of 15 branchiostegal teeth along entire margin.

Description.-The general morphology of this species, as far as can be determined, is similar to that of $P$. cooperi. The main points of difference are as follows: the exoskeleton is completely covered 


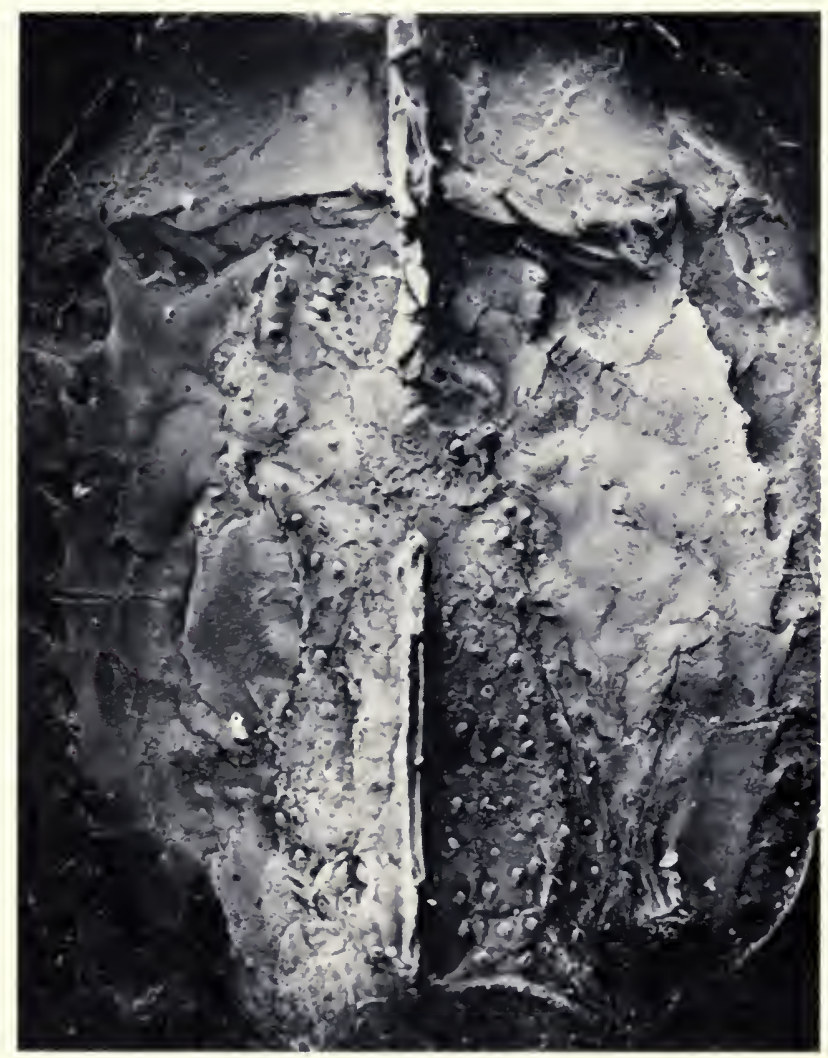

FIG. 40. Pygocephalus dubius (Prestwich), 1840. GSL 54399, holotype, latex mold, $2.8 \times$.

with a surface ornamentation of fine papillations. Some specimens (GSL 35038; GSL Z1 2148: GSL Z1 1855; K 01-53pc, fig. 42a; I 44952; I 44957) have the surface papillations markedly reduced to an area just along the cervical groove. These specimens are all toward the small end of the range for $P$. dubius, as determined by Rhodes and Wilson (1957) and, although this decoration is quite distinctive, other aspects of their anatomy seem to require that these specimens be placed as peculiar variants among the younger individuals of $P$. dubius.

There are on the average 15 branchiostegal serrations which are distributed all along the lateral margin of the carapace. The carapace also has a distinct mid-dorsal keel (GSL 58339, fig. 41). 


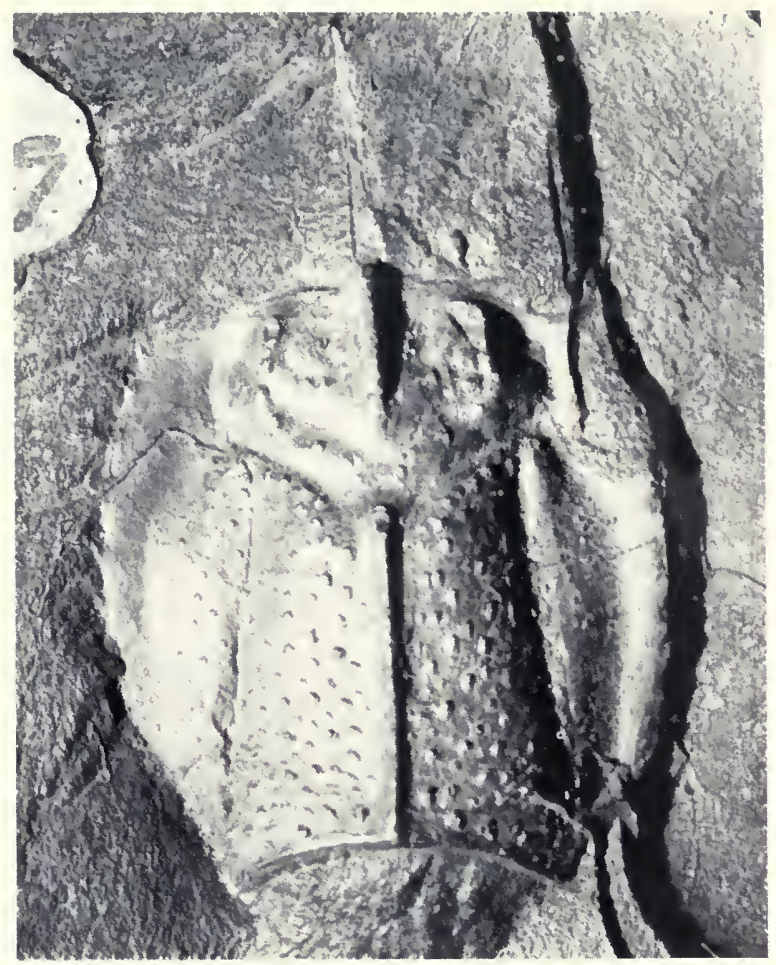

Fig. 41. Pygocephalus dubius (Prestwich), 1840. GSL 58339, with papillose decoration of cuticle and mid-dorsal ridge on carapace, $2.9 \times$.

TABLE 15. Measurements in centimeters of the carapace midline of specimens of Pygocephalus dubius which have the minimal carapace ornament.

$\begin{array}{lr}\text { specimen } & \text { carapace } \\ \text { GSL } 35038 & 1.16 \\ \text { GSL Z1 } 1855 & .60 \\ \text { GSL Z1 2148 } & .32 \\ \text { K 01-53pc } & 1.50 \\ \text { In } 44952 & 1.65 \\ \text { In } 44957 & 1.13 \\ \overline{\mathrm{x}} & 1.06\end{array}$



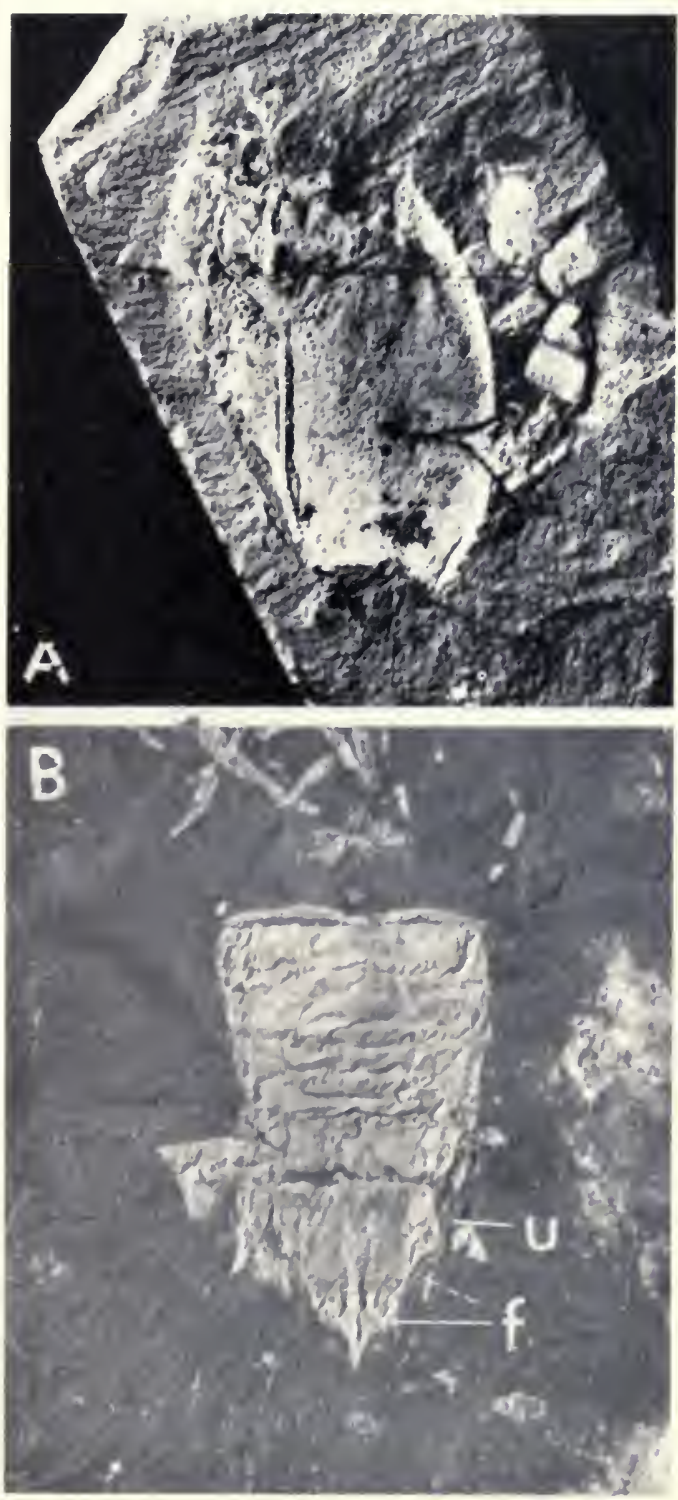

FIG. 42. Pygocephalus dubius (Prestwich), 1840. A, K 01-53pc, morphological variant with papillations reduced to a line along the cervical groove, $2.7 \times$. B, GSL 30280 , tailfan with base of uropods ( $\mathrm{u}$ ) and double furcae on telson (f), $2.8 \times$. 
TABLE 16. Measurements in centimeters of some representative specimens of typically ornamented Pygocephalus dubius. *indicates holotype. (Carapace length not to be compared to Rhodes and Wilson (1957) who do not measure length at the dorsal midline as I have done.)

$\begin{array}{llll}\text { specimen } & \text { carapace } & \text { rostrum }\end{array}$

GSL 54399*

GSL 30281

GSL 30283

R 1957.1.5080

2.40

.68

1.55

R 1957.14

2.20

.86

1.85

GSE 4757

GSE 4759

1.50

.50

GSE 4760

2.63

1.04

GSE 5832

1.10

.55

GSE 5833

2.07

.63

GSE 5834

1.58

.43

GSE 5835

2.27

.70

GSE 5836

2.30

.72

$\overline{\mathbf{x}}$

2.06

.68

All other features of the anatomy correspond to $P$. cooperi including the double pair of caudal furca (GSL Za 3068, GSL 30280, fig. $42 \mathrm{~b})$. The caudal spine of $P$. dubius is slightly more pointed than that of $P$. cooperi. Unfortunately, $P$. dubius fossils are not usually preserved with the ventral side displayed and those that are, are poorly preserved (GSL 88801).

Measurements are given in Tables 15 and 16, a reconstruction in Figure 39c, d.

Pseudotealliocaris Brooks, 1962b

Type species.-Pseudotealliocaris caudafimbriata (Copeland) 1957. West Bay, near Parrsboro, Nova Scotia; Canso Group, Upper Carboniferous. 


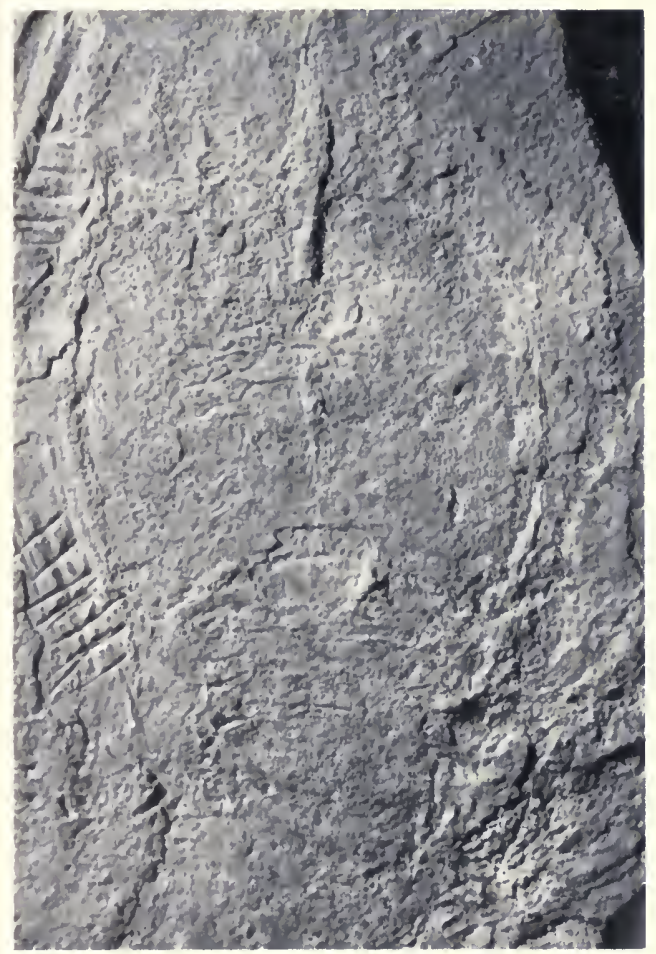

Fig. 43. Pygocephalus dubius (Prestwich), 1840. R 1974.14, poorly preserved specimen exhibiting secondary diagenetic pitting (this specimen was the type of $A n$ thrapalaemon russelianus), $1.8 \times$.

Diagnosis. - Carapace as wide as long. Large antero-lateral spines. Carapace with median keel and two pairs of lateral carinae.

\section{Pseudotealliocaris etheridgei (Peach), 1882. Figures 44, 45. Table 17.}

\footnotetext{
v*. 1882 Anthrapalaemon etheridgei Peach, p. 176, pl. 8, figs. 3-3g.

v. 1882 Anthrapalaemon formosus Peach, p. 83, pl. 8, fig. 8 .

v. 1883 Anthrapalaemon formosus Peach. Peach, p. 512, pl. 28, figs. 3-3b.

v. 1883. Anthrapalaemon etheridgei lata Peach, p. 513, pl. 28, figs. 4-4b.

1903 Anthrapalaemon etheridgei Peach. Peach and Horne, p. 846.

1903 Anthrapalaemon etheridgei lata Peach. Peach and Horne, p. 846.

1903 Anthrapalaemon formosus Peach. Peach and Horne, p. 846.

v. 1908 Tealliocaris etheridgei (Peach). Peach, p. 22, pl. 3, figs. 1-2.

v. 1908 Tealliocaris etheridgei lata (Peach). Peach, p. 123, pl. 3, figs. 3, 4 .

v. 1908 Tealliocaris robusta Peach, p. 24, pl. 3, figs. 5-8.

v. 1908 Tealliocaris robusta var. Peach, pl. 25, pl. 3, figs. 9-12.

v. 1908 Tealliocaris formosa (Peach). Peach, p. 27, pl. 3, figs. 17, 18.

1911 Tealliocaris etheridgei (Peach). Woodward, p. 363.

1911 Tealliocaris etheridgei lata (Peach). Woodward, p. 363.

1911 Tealliocaris robusta Peach. Woodward, p. 363.

1911 Tealliocaris robusta var. Peach. Woodward, p. 363.

1911 Tealliocaris formosa (Peach). Woodward, p. 363.
} 
$1969 a$ Tealliocaris robusta Peach. Schram, p. 216, table 1.

1969 a Tealliocaris etheridgei (Peach). Schram, p. 216, table 1.

1969a Tealliocaris formosa (Peach). Schram, p. 216, table 1.

Lectotype (here designated).-GSE 5918 (fig. 44a); River Esk, Glencartholm, 11/2 miles below Langholm, Dumfriesshire; Glencartholm Volcanic Beds, Calciferous Sandstone Measures.

Diagnosis. - Cuticle pitted. Carapace with no grooves at base of rostrum and relatively weak mid-dorsal keel. Cervical groove lies about one-fourth the length of carapace from anterior end.

Description.-The exoskeleton is decorated with a scattered ornament of small pits (GSE 5942, E 13473-5). The rostrum is moderately long, weakly falciform, less than one-fourth the mid-dorsal length of the carapace. There is a faint mid-dorsal carina and a set of cervical grooves which meet in the midline. The grooves start from the margin of the carapace some distance behind the antero-lateral spines and proceed in a sigmoid path to the midline (GSE 5921). The gastric spine is small. Posterior to the cervical groove are two pairs of longitudinal ridges, the more lateral pair being the stronger $(\mathrm{R}$ 1887.25.1034). The posterior margin of the carapace is excavated and the branchiostegal lappets greatly developed (fig. 44c).

The segments of the first antennal peduncles are somewhat subequal in length with a slight tendency for the segments to shorten as one moves distally (GSE 5919). The second antenna has a peduncle of three segments; the most proximal and most distal are both about a quarter of the total length of the peduncle and the middle is about half the length. The scaphocerite is oval (GSE 5922) with the lateral margin heavily sclerotized and terminating in a spine; the medial margin of the scale is setose.

Little can be discerned concerning the thoracopods since they are not clearly preserved on any of the specimens at hand. GSE 5918 (fig. 44a) has clearly preserved the thoracic sternites in their characteristic triangular field, but all else is obscured.

The pleura of the abdominal segments are pointed and the tergites themselves are longitudinally marked with a pair of lateral ridges (GSE 5942), while the sixth pleomere also has a median ridge. The telson is subtriangular with medium-sized caudal lobes taking origin about halfway along its length. The distal end of the telson is deeply excavated so as to form a pair of spines (GSE 5922, fig. 44b; E 13470) flanking the rounded caudal lobe. The telson has a median dorsal ridge and a pair of incipient lateral ridges ( $R$ 1887.25.1936). 

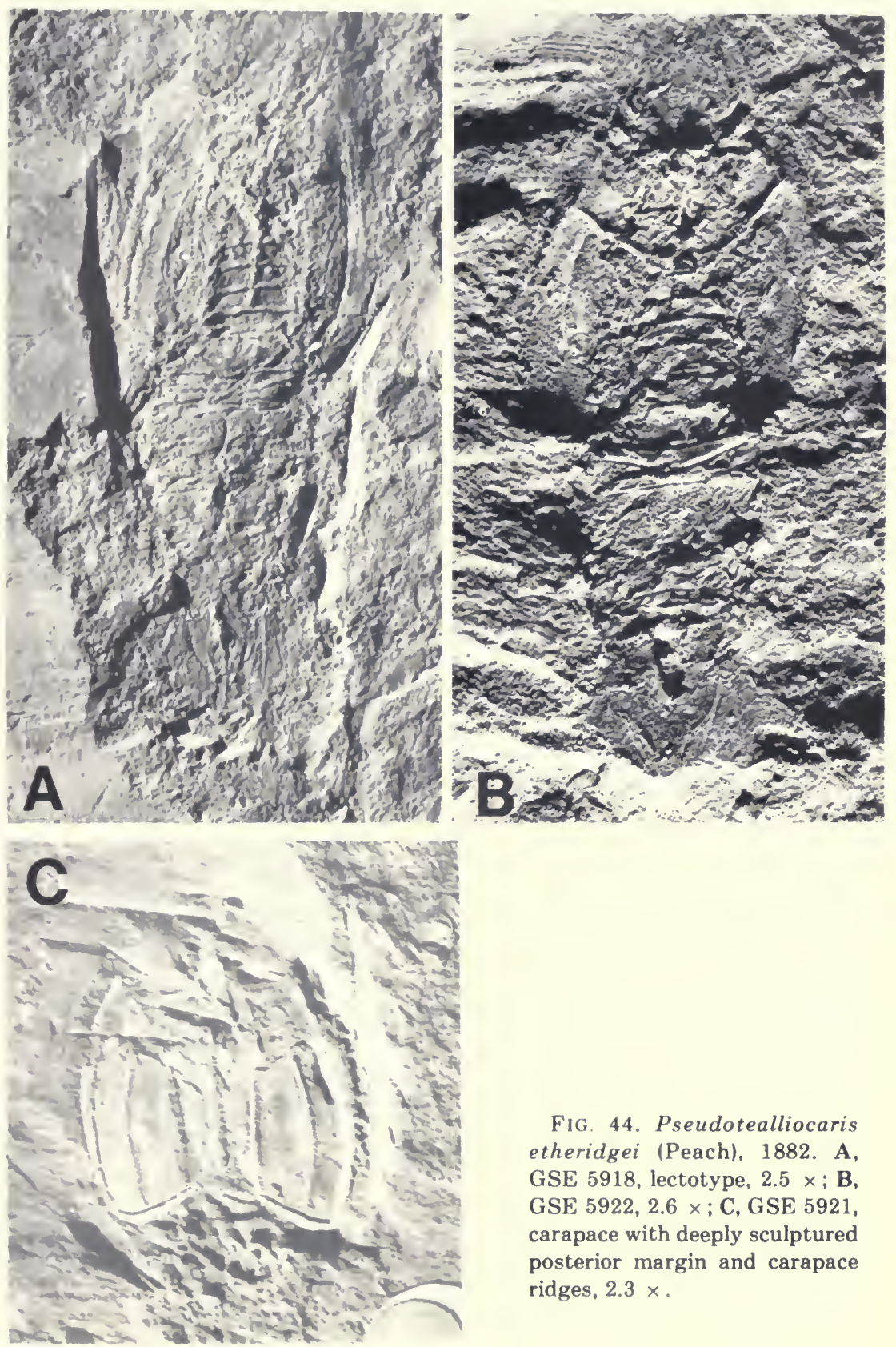

FIG 44. Pseudotealliocaris etheridgei (Peach), 1882. A, GSE 5918, lectotype, $2.5 \times$; B, GSE 5922, $2.6 \times$; C, GSE 5921, carapace with deeply sculptured posterior margin and carapace ridges, $2.3 \times$. 
FIG. 45. Pseudotealliocaris etheridgei (Peach), 1882. Reconstruction, scale $5 \mathrm{~mm}$.

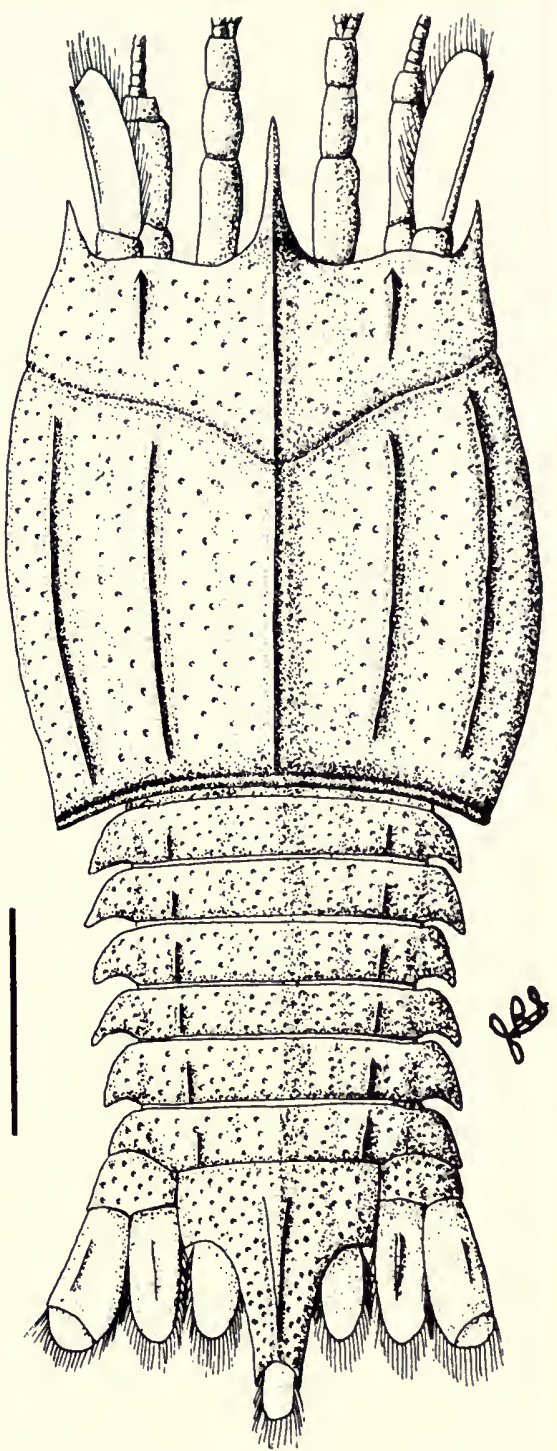

The lobate uropods have a deeply sigmoid exopodal diaresis (GSE 5922). All the lobes of the tail fan are marginally setose and stand separate from each other so as to not form a neatly continuous fan with overlapping lobes.

Remarks.-Pseudotealliocaris etheridgei is strikingly similar to the Canadian species $P$. caudafimbriata. The differences are subtle. 
TABLE 17. Measurements in centimeters of some representative specimens of Pseudotealliocaris etheridgei. **indicates lectotype.

specimen

GSE 5918**

GSE 5917

GSE 5919

GSE 5920

GSE 5922

GSE 5925

GSE 5927

GSE 5928

GSE 5941

GSE 5942

GSE M 438

R 1887.25.1033

R 1887.25.1034

R 1887.25.1035

$$
\text { carapace }
$$

1.23

1.0

1.83

1.30

.96

.34

.34

.92

.92

$\overline{\mathbf{x}}$

$P$. caudafimbriata has an accessory groove on the carapace flanking the base of the rostrum, the cervical groove arises somewhat more closely to the antero-lateral spine, the keels on the carapace are all strongly marked, and the most lateral lie very close to the lateral edge. $P$. caudafimbriata is found in the Canadian Namurian (Canso Group), while $P$. etheridgei is Viséan.

Some measurements of $P$. etheridgei are offered in Table 17, a reconstruction in Figure 45.

Order: Tanaidacea Dana, 1853

Suborder: Monokonophora Lang, 1956

Family: Anthracocarididae Brooks, 1962b (emended herein) 
Type genus.-Anthracocaris Calman, 1932. River Esk, Glencartholm, Dumfriesshire; Calciferous Sandstone Measures.

Diagnosis.-Monokonophoran tanaidaceans with sixth pleomere and telson unfused.

Remarks. - This family also includes Cryptocaris hootchi Schram, 1974b from the Mazon Creek Essex Fauna of northeastern Illinois (Westphalian C).

\section{Anthracocaris Calman, 1932}

Type species.-Palaeocaris scotica Peach, 1882. River Esk, Glencartholm, 11/2 miles below Langholm, Dumfriesshire; Glencartholm Volcanic Beds, Calciferous Sandstone Measures.

Diagnosis. - Cuticle smooth and relatively unornamented. Rostrum small. Telson subrectangular and terminally lobate. Uropods multisegmented.

Anthracocaris scotica (Peach), 1882. Figures 46, 47. Table 18.

v*. 1882 Palaeocaris scotica Peach, p. 85, pl. 10, figs. 10-10b.

1883 Palaeocaris scotica Peach. Peach, p. 515.

1903 Palaeocaris scotica Peach. Peach and Horne, p. 846.

v. 1908 Palaeocaris scotica Peach. Peach, p. 154, pl. 8, figs. 1-5.

1911 Palaeocaris scotica Peach. Woodward, p. 363.

1933 Anthracocaris scotica (Peach). Calman, p. 562, fig. 1.

$1962 a$ Anthracocaris scotica (Peach). Brooks, p. 239.

$1962 b$ Anthracocaris scotica (Peach). Brooks, p. 216

1969 Anthracocaris scotica (Peach). Hessler, p. R392, fig. 211,1.

1969a Anthracocaris scotica (Peach). Schram, p. 218, table 1.

1974b Anthracocaris scotica (Peach). Schram, p. 107.

Lectotype (here designated).-GSE 5803 (fig. 46a); River Esk, Glencartholm, Dumfriesshire; Calciferous Sandstone Measures.

Diagnosis. - Since there is only one species, the diagnosis is the same as for the genus.

Description.-The carapace covers the first two thoracomeres and has a slight branchiostegal development (GSE 5803; 5807, fig. 46b). The carapace is about half as long as the combined length of the posterior six thoracomeres and has slight antero-lateral spines. The rostrum and optic notch are small. GSE 5807 has what appears to be a small, spherical, stalked eye. The first antennal peduncle has three subequal segments, while the second antennal peduncle appears to be slightly larger and longer than the first with two subequal segments. 

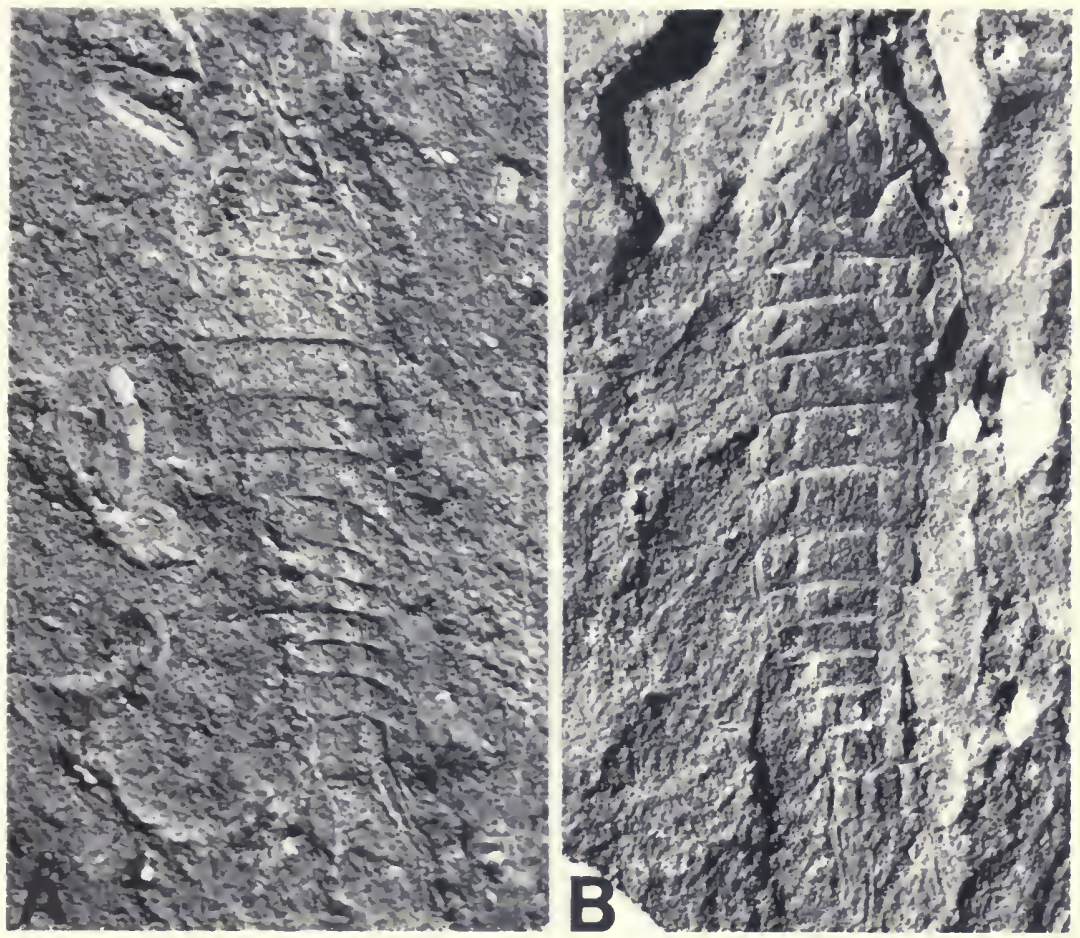

FIG. 46. Anthracocaris scotica (Peach), 1882. A, GSE 5803, lectotype, $5.6 \times$; B, GSE 5807, $9.8 \times$.

GSE 5805 preserves some parts of the thoracopods. Little can actually be discerned concerning their details beyond saying that the appendage at the anterior end of the series is larger than any of the others and that there is a segment near the base of these appendages which is longer and wider than any of the others. GSE 5805 also has parts of a flap-like pleopod.

The exoskeleton is undecorated except for a slight pair of ridges on the six exposed thoracomeres and on the three posterior pleomeres (GSE 5807, fig. 46b). The abdomen is three-fourths the length of the six exposed thoracomeres. All six pleomeres are separate segments.

The telson is rectangular with a distal constriction delineating a terminal, spatulate lobe (GSE 5803, 5807). The uropods appear to have only one branch (GSE 5803, 5805, 5809); they are long, extending at least beyond the end of the telson, and are composed of many, discrete segments. 

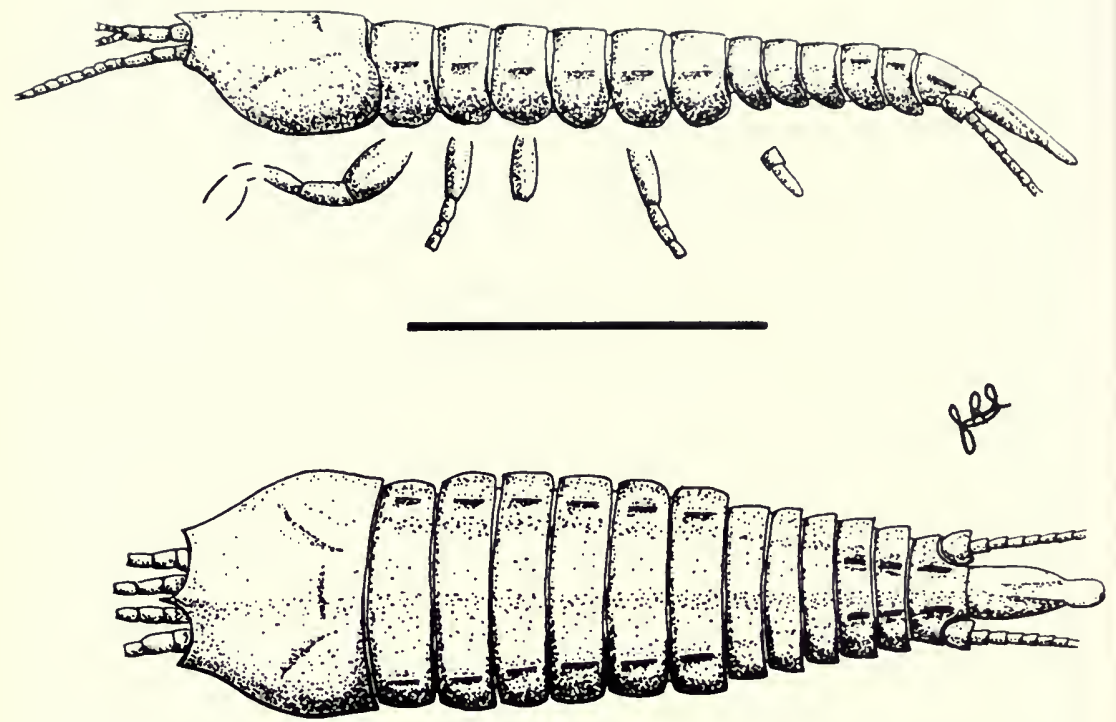

FIG. 47. Anthracocaris scotica (Peach), 1882. Reconstruction, scale $5 \mathrm{~mm}$.

TABle 18. Measurements in centimeters of specimens of Anthracocaris scotica. **indicates lectotype.

$\begin{array}{lcccc}\text { specimen } & \text { carapace } & \begin{array}{c}\text { thoracomeres } \\ 2-8\end{array} & \text { abdomen } & \text { telson } \\ \text { GSE 5803** } & & .52 & .40 & .20 \\ \text { GSE 5806 } & & .56 & .40 & .18 \\ \text { GSE 5807 } & .17 & .36 & .26 & .15 \\ \text { GSE 5808 } & .34 & .50 & .36 & \\ \text { GSE 5809 } & & .31 & .22 & \\ \text { GSE 5810 } & .14 & .27 & .20 & \\ \text { GSE 5811 } & .12 & .32 & .24 & \\ \text { GSE 5812 } & .13 & .27 & .20 & \\ \text { E } 13493 & .15 & & & \\ \text { In } 36866 & .30 & .39 & .28\end{array}$


Remarks. - There is little doubt that Anthracocaris is a tanaidacean. Thus along with the assignment of the other "anthracocaridaceans" to various groups, [Acadiocaris novascotica to the Spelaeogriphacea (Schram, 1974a) and Acadiocaris lansboroughi to the Syncarida (see below)], the order Anthracocaridacea Brooks 1962b, ceases to exist.

Anthracocaris is closely related to Cryptocaris Schram 1974a, which is distinguished from Anthracocaris by having cuticular ornamentation, greater development of the branchiostegum, a rounded telson, and uropods with few elements. The tanaid features of Anthracocaris are the smallness of the abdomen as compared to the thorax, the multisegmented uropods, and an enlarged anterior thoracopod (though it can not yet be verified if the large appendage is in fact the second thoracopod, and it is developed as a cheliped).

The occurrence of $A$. scotica in the Lower Carboniferous emphasizes the ancient origins and rapid delineation of the basic peracaridan orders.

Measurements are given in Table 18, a reconstruction in Figure 47.

Superorder: Syncarida Packard, 1885

Order: Palaeocaridacea Brooks, 1962b

Family: Pleurocarididae Chappuis, 1915

\section{Pleurocaris Calman, 1911a}

Type species.-Pleurocaris annulatus Calman, 1911a. Clay Croft works Coseley, Worcestershire; Lower Similis-Pulchra Zone, Middle Coal Measures.

Diagnosis. - Cephalon small with two cephalic grooves not joined laterally. Large thoracic pleura. Uropodal rami and telson styliform.

Pleurocaris annulatus Calman, 1911a. Figures 48, 49. Table 19.

? 1881 Palaeocaris burnetti Woodward, p. 534, pl. 14, figs. 3a, 3b.

v*. 1911 a Pleurocaris annulatus Calman, p. 156, fig. 1.

v. 1911 b Pleurocaris annulatus Calman. Calman, p. 494, fig. 5.

1915 Pleurocaris annulatus Calman. Chappuis, p. 173.

$1962 a$ Pleurocaris annulatus Calman. Brooks, p. 236.

1969 Pleurocaris annulatus Calman. Brooks, p. R355, fig. 169,5.

1969 a Pleurocaris annulatus Calman. Schram, p. 220, table 1.

? 1969 a Palaeocaris burnetti Woodward. Schram, p. 220, table 1. 


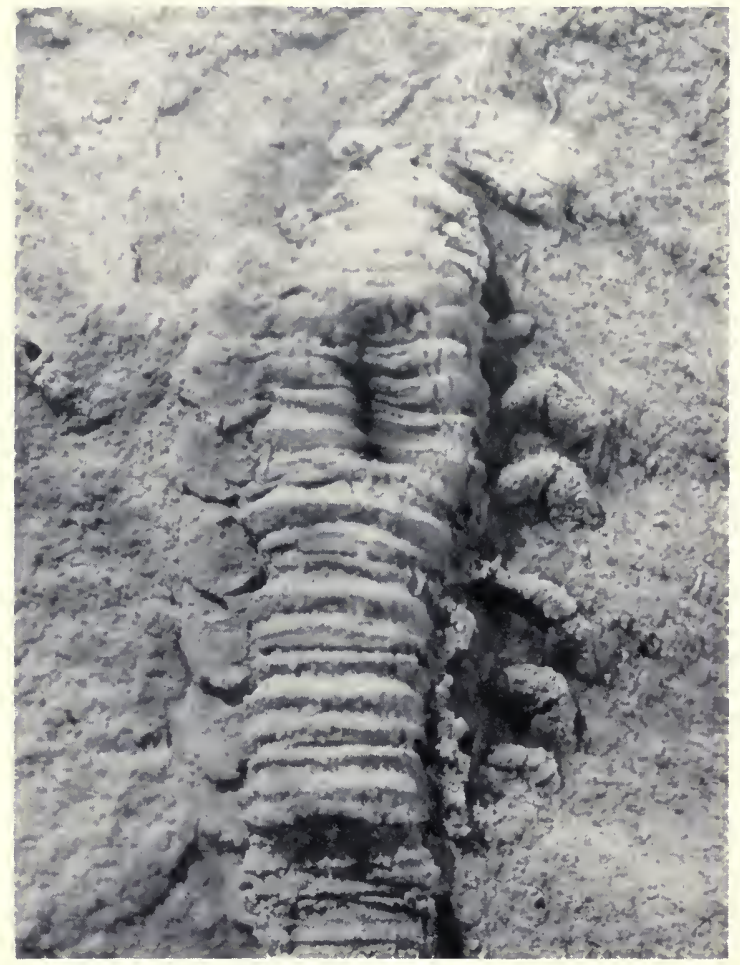

Fig. 48. Pleurocaris annulatus Calman, 1911. In 13814, latex mold displaying the cephalothorax (the best preserved specimen of the species), $12.4 \times$.

Holotype. - In 29008. Clay Croft open works, Coseley, near Dudley, Worcestershire; $10 \mathrm{ft}$. Ironstone Measures, Lower Similis-Pulchra Zone, Middle Coal Measures.

Remarks. - Nothing can be added to Calman's description of this species. Calman was accurate in his observations and Brooks' (1969) reconstruction adequately reflects what is known about this species. Specimen I13814 is the best preserved (fig. 48).

Table 19 contains some measurements of specimens and a lateral reconstruction is offered in Figure 49.

The original specimen of Palaeocaris burnetti Woodward, 1881, is lost. The basis for this species was a single specimen from the "Middle Coal Measures, River section Irwell Valley" in the collection of Mr. Robert F. Burnett, F.G.S., of Manchester. The description is not very revealing. The telson and uropods were "lanceolate," which would indicate it was not Palaeocaris. The 14 somites were all about 
$2 \mathrm{~mm}$. in length. Up to this point we might be dealing with a Pleurocaris annulatus, however, the presence of 8 to 10 laterally directed striations per somite, and no mention of prominent thoracic pleura

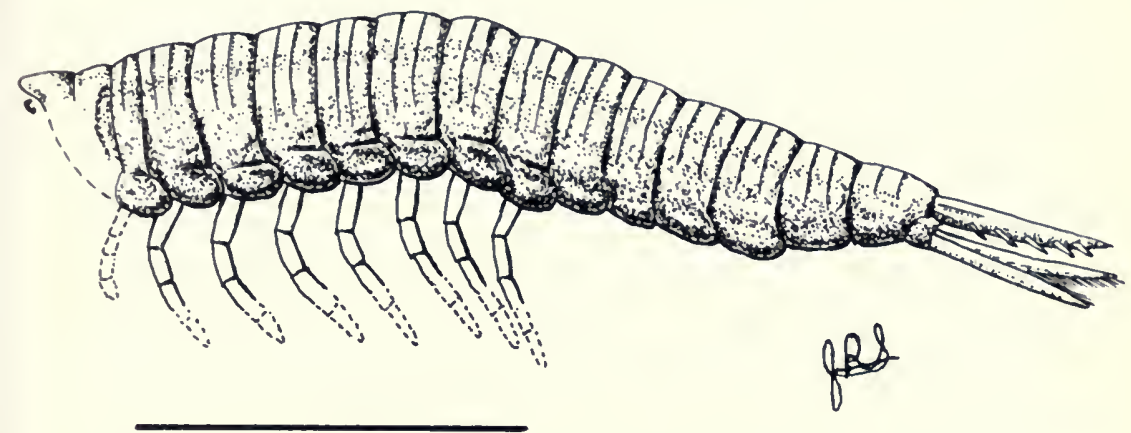

Fig. 49. Pleurocaris annulatus Calman, 1911. Reconstruction, scale 5 mm.

causes one to pause from placing this species with $P$. annulatus. Furthermore, Woodward ends his description with a comparison to the Permian phreatoicidean isopod, Palaeocrangon (Prosoponiscus) problematicus. The illustration is not very helpful.

There is no effective way to decide what this species might have been. We might even question its being a syncarid. It might have been a rather aberrantly preserved Pleurocaris annulatus. The name has practically dropped out of use since it was described. I see no reason to suppress the well-known and established form on the basis of a suspected synonymy with no type to base it on.

TABLE 19. Measurements in centimeters of the measurable specimens of Pleurocaris annulatus. ${ }^{*}$ indicates holotype.

specimen

In $29008^{*}$

In 29009

I 13813

I 13814

I 14449 total

abdomen

.58

.57

.23 
Family: Palaeocarididae Meek and Worthen, 1865

Palaeocaris Meek and Worthen, 1865

Type species.-Palaeocaris typus Meek and Worthen, 1865. Mazon Creek, Grundy County, Illinois; Francis Creek Shale, Middle Pennsylvanian (Westphalian C).

Diagnosis. - Thoracic and abdominal pleura generally rounded on anterior margin and straight along posterior margin. Telson oval and setose. Epipods, thoracic exopods, and pleopods flap-like. No raptorial thoracopods.

Remarks. - The genus Palaeocaris has acted in the past as a catchall for every non-descript Paleozoic syncarid. Schram and Schram (1974) have shown that not all Palaeocaridacea have flap-like thoracic exopods and pleopods. These flap-like structures were once thought to be characteristic of the order. One is very hard put to make a definitive, distinctive set of characters which adequately delineate the genus Palaeocaris.

At present, any syncarid which has a relatively undecorated cuticle, has simple pleura and unmodified appendages, and a plain tailfan (whatever these adjectives mean) is termed Palaeocaris. This is unsatisfactory and it should be recognized that a revision of the genus Palaeocaris is in order with a re-examination of all available material-something beyond the scope of this work. The two species, $P$. typus and $P$. retractata, are closely related and will form the nucleus of the genus Palaeocaris in any future revision.

Palaeocaris retractata Calman, 1932. Figures 50, 51. Table 20.

v. 1911 Palaeocaris praecursor (Woodward). Calman, p. 488, figs. 1, 2a, 3.

v. 1914 Palaeocaris sp. Peach, p. 146, fig. 9.

* 1932 Palaeocaris retractata Calman, p. 541.

1961 Palaeocaris retractata Calman. Rolfe, p. 546, pl. 68, fig. 8, text-fig. 1. $1962 b$ Palaeocaris retractata Calman. Brooks, p. 248.

Holotype. - In 29012 (fig. 50a); Clay Croft open works, Coseley near Dudley, Worcestershire; $10 \mathrm{ft}$. Ironstone Measures, Lower Similis-Pulchra Zone, Middle Coal Measures.

Diagnosis. - Sixth thoracomere undistinguished from any others. Antennal scaphocerite small. Outer margin of uropod exopods with prominent spines.

Description.-The cephalic shield is smooth, without any ornamentation. The eyes are small and stalked (In 29012, fig. 50a; 29013, 

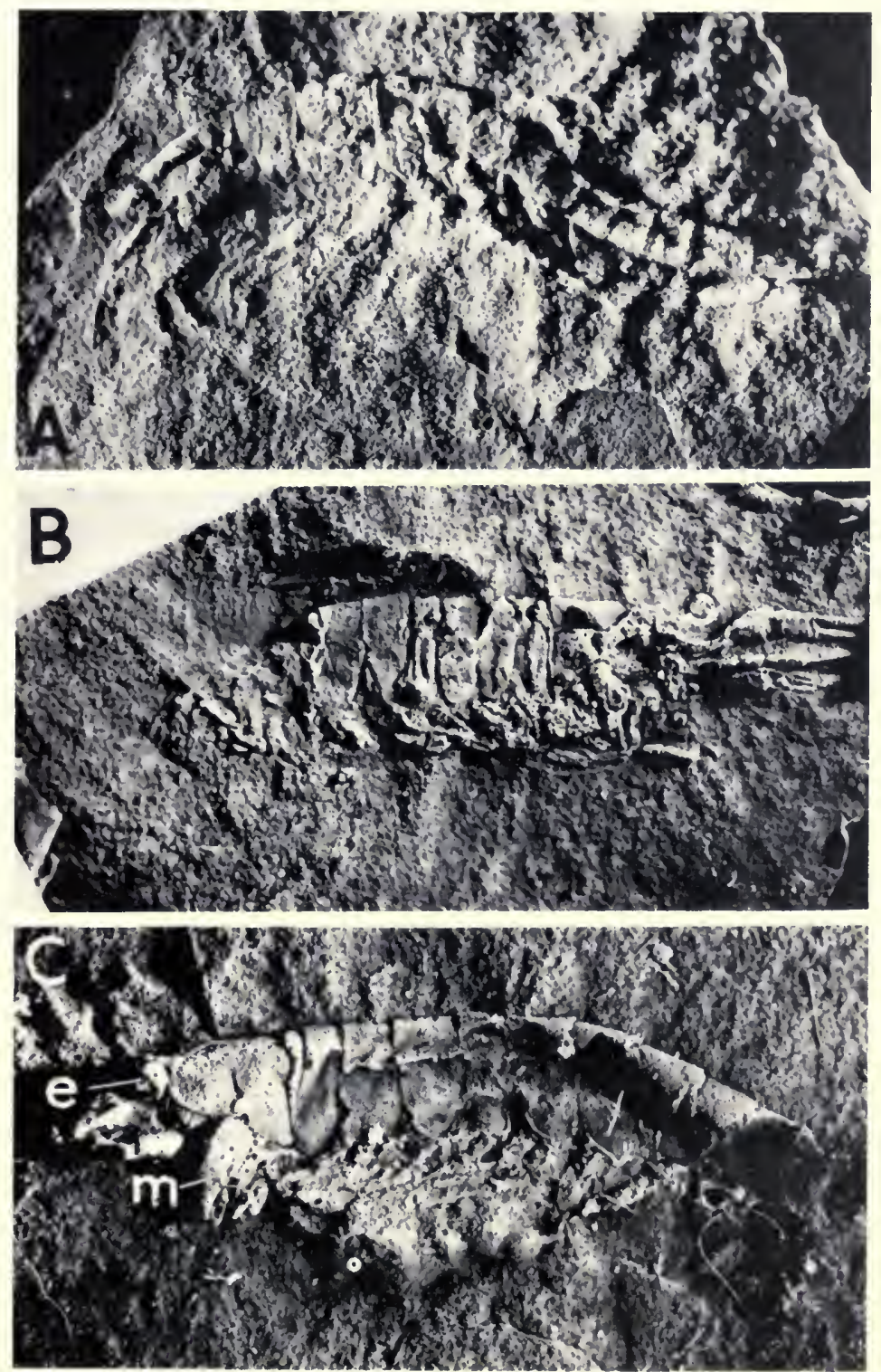

Fig. 50. Palaeocaris retractata Calman, 1932. A, In 29012, holotype, $6.1 \times$; B, In 29023 with optic notch on antenna (o), $5.8 \times$; C, In 29013, stalked eye (e), mandible (m), and note markedly reduced first thoracomere just posterior to cephalon, $6.3 \times$. 
fig. 50c). The mandibles are large and armed with an incisor process (In 29013). Nothing is known about the maxillae. The first antennal peduncle has three subequal elements and an optic notch on the most proximal segment (In 29023, fig. 50b). The two flagella of the first antenna are of unknown length. The second antenna has a small scaphocerite (In 29021) arising from the second segment of the peduncle.

The first thoracomere is reduced and the associated appendage developed as a large palp. Thoracomeres two through eight are subequal. The thoracomeres two through four are squared off in outline, while the remaining pleura are more attenuated in front. All the pleura have slight doublures. The pereiopods have a short coxa and basis. The exopod is flap-like (In 29014). The endopod segments are somewhat subequal with a tendency to decrease in length as one proceeds distally (In 29021). The epipods may have been flaplike (BU 733).

The first five pleomeres are subequal, while the last is elongate. Pleomeres two through six have a slight fringe of spines (In 29012) along their posterior margins. Nothing is known about the pleopods. The telson is spatulate and decorated with a fringe of spines (In 29024, I 13973). The uropodal exopod has a slightly sigmoid diaresis and is armed with spines along its lateral margin and setae on the distal lobe (In 29024). The uropodal endopod is simple, setose; and while not quite as long as the exopod, longer than the telson.

Remarks. - There are several differences between $P$. retractata
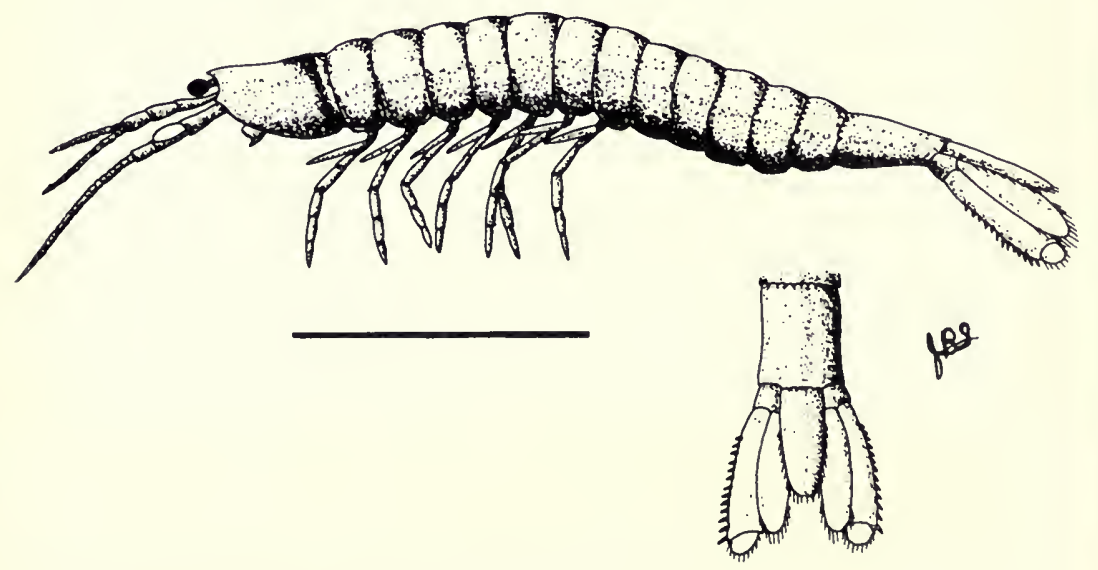

FIG. 51. Palaeocaris retractata Calman, 1932. Reconstruction, scale $5 \mathrm{~mm}$. 
and $P$. typus of North America. The sixth thoracomere of $P$. typus is larger than any of its other segments. The scaphocerite of $P$. typus is bigger than that of the British species. The ischium of $P$. typus thoracopods is smaller and the diaresis on the uropodal exopod is straight.

Within the qualifications set down in the remarks under the genus Palaeocaris, $P$. typus and $P$. retractata are fairly closely related and thus form a nucleus for an eventually more cohesive genus.

Measurements are given in Table 20, a reconstruction in Figure 51.

TABLE 20. Measurements in centimeters of some representative specimens of Palaeocaris retractata. *indicates holotype.

specimen

In $29012^{*}$

In 29013

In 29014

In 29021

In 29023

In 29024

I 13973

BU 733

$\overline{\mathbf{x}}$

.20

.16

.22 thorax

.55

.74

.55

.50

67

.38

.56

.30

.54

.42

.58

telson
.49

9

Minicaris gen. nov.

Type species. - Minicaris brandi sp. nov. Long Livingston Borehole no. 25, Lower Oil Shale Group.

Diagnosis.-Peduncles of first and second antennae subequal. First thoracomere equal in size to any other thoracomere. Ui:opods blade-like. Pleotelson.

Minicaris brandi sp. nov. Figures 52, 53.

Etymology.-This species is named in honor of Mr. Peter Brand, I.G.S., Edinburgh, who brought this specimen to my attention, and assisted me greatly in examining the I.G.S. collections. 
Fig. 52. Minicaris brandi sp. nov. A, GSE 13056, holotype, $11.6 \times$; B, GSE 13056, close-up of tailfan with sixth pleomere $(\mathrm{s}), \operatorname{uropod}(\mathrm{u})$, and telson (t), 22 $\times$.

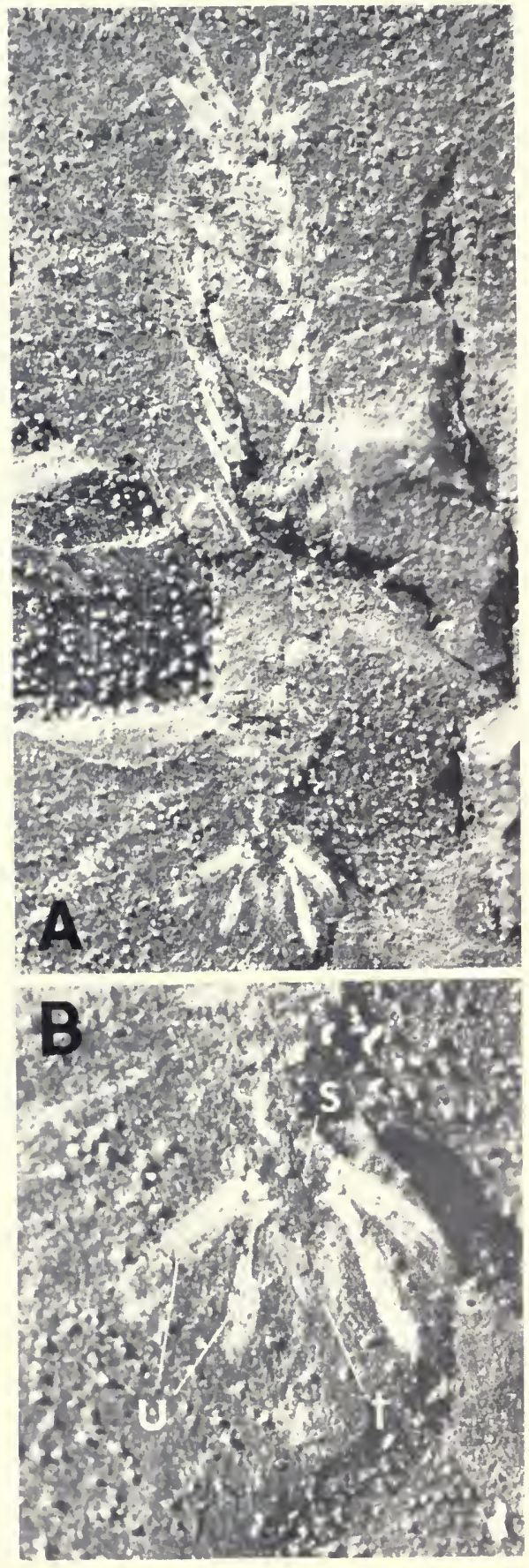


Holotype.-GSE 13056 (fig. 52); Long Livingston Borehole no. 25, $1,071 \mathrm{ft}$. to $1,151 \mathrm{ft}$. section; Beds below the Pumpherstone Shell Bed, Lower Oil Shale Group.

Diagnosis.-Since there is one species, the diagnosis is the same as that of the genus.

Description.-The first antennal peduncle has three segments: the most proximal is half the total length of the peduncle and relatively wide, while the two distal segments are each progressively shorter. Only one of the two flagella of the first antenna is preserved on the type, GSE 13056 (fig. 52). The second antennal peduncle has four segments: the most proximal is one-fifth the total length of the peduncle, the second is about two-fifths the length and marked with a faint longitudinal ridge, and the third and fourth segments are each about one-fifth the total length. An oval scaphocerite with long setae on its margin arises from near the end of the second segment of the peduncle and extends beyond the distal end of the peduncle. The peduncles of both antennae are about equal in length.

All eight thoracomeres are the same length. The pleura are rounded with the posterior corner somewhat pointed. The thoracic exopods are flap-like and narrow. The endopod has a long ischium, short and equal merus and carpus, and propodus somewhat longer than the carpus, and a short dactylus. This arrangement of the thoracopods is only verifiable for the posterior appendages. The first

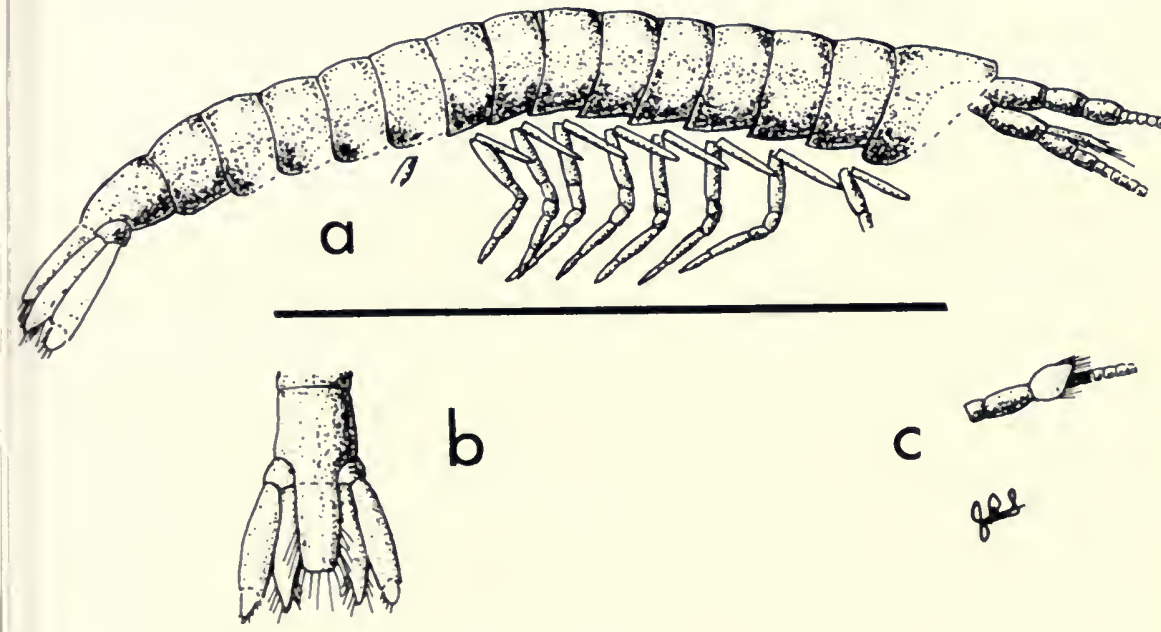

FIG. 53. Minicaris brandi sp. nov. Reconstruction, scale $5 \mathrm{~mm}$. A, lateral view; B, dorsal view of tail fan; $\mathrm{C}$, dorsal view of second antenna. 
thoracopod appears to be similar to these but is the most poorly preserved.

Little can be said about the abdominal segments. They were about equal in size and pleopods were present. No clear suture between the sixth pleomere and telson can be seen on the type specimen, though the arrangement of structures in that region may seem to indicate a pleotelson. The telson is spade-like in form and decorated with long setae. The uropods are blade-like, about half again as long as the telson and decorated with setae (fig. $52 \mathrm{~b}$ ). There may be a rounded diaresis on the exopod.

Remarks.-Unfortunately, there is only one decently preserved individual of this species on a single slice of a well core. Other material of this species on both sides of the slice is generally very poor.

Minicaris is tentatively placed within the Palaeocarididae, but is readily distinguished from other genera by the large first thoracomere as well as its other characters. It is very small; the holotype is $8 \mathrm{~mm}$. in total length.

The nature of the first thoracomere and rather generalized thoracopods make $M$. brandi the most primitive of syncarids. $M$. brandi might be closer to an ancestral syncarid type than any other known form. From such a form one could derive the specialized Bathynellacea (with eight equally developed thoracomeres), as well as the Palaeocaridacea-Anaspidacea line (with a de-emphasis and eventual incorporation of the first thoracomere into the cephalon).

More and better specimens may eventually justify the erection of a separate family for the genus. For the time being it is placed in the family Palaeocarididae. A reconstruction is offered in Figure 53.

Family: Squillitidae Schram and Schram, 1974

Praeanaspides Woodward, 1908

Type species. - Praeanaspides praecursor Woodward, 1908. Shipley Hall, Derbyshire; Clay Ironstone, top Modiolaris Zone, Middle Coal Measures.

Diagnosis. - First thoracomere very reduced. Biramous annulate pleopods. Uropodal diaresis. Telson rectangular in outline and spinous.

Praeanaspides praecursor Woodward, 1908. Figures 54, 55. Table 21.

v*. 1908 Praeanaspides praecursor Woodward, p. 385, figs. 1-5. 

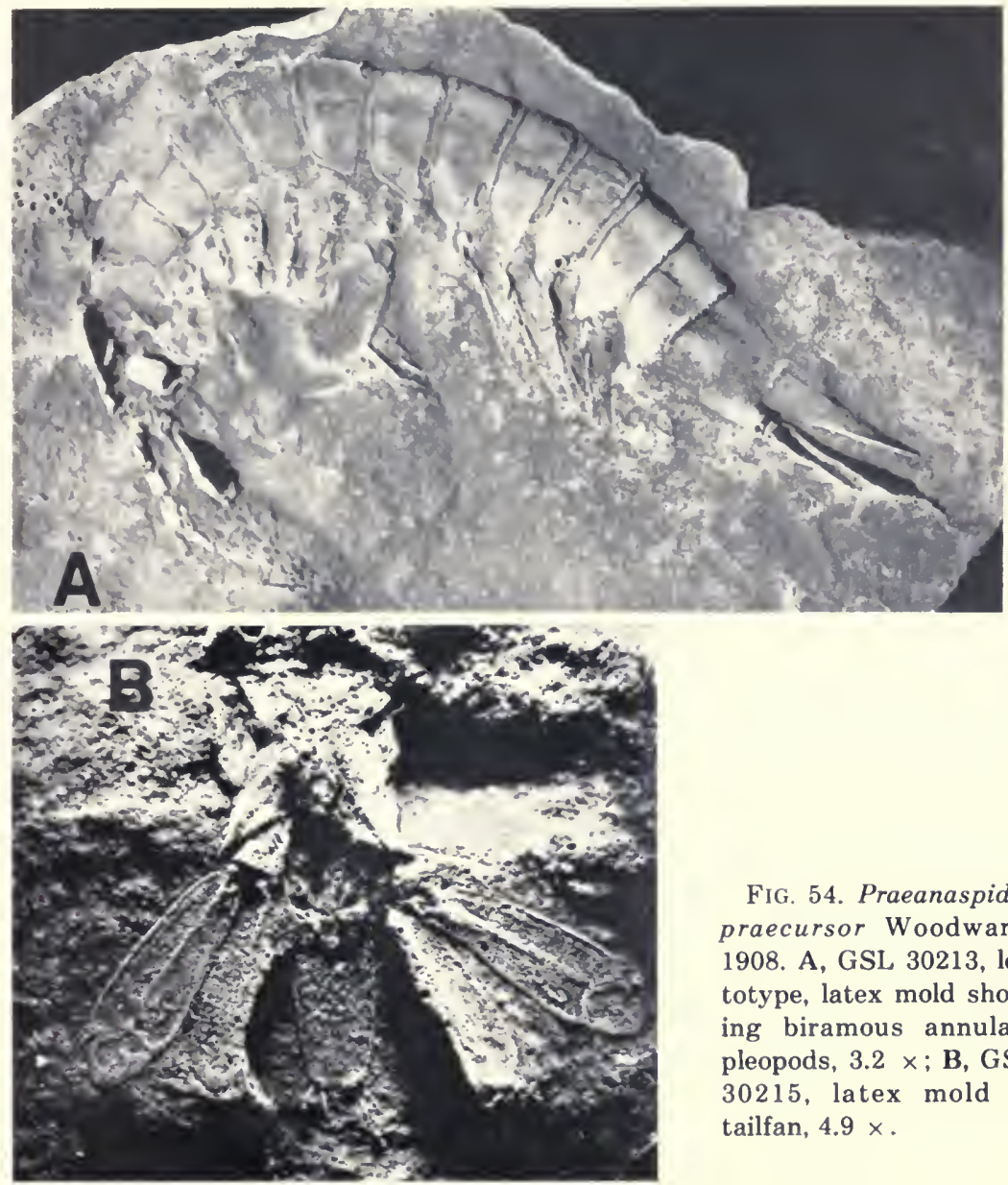

Fig. 54. Praeanaspides praecursor Woodward, 1908. A, GSL 30213, lectotype, latex mold showing biramous annulate pleopods, $3.2 \times ; \mathrm{B}$, GSL 30215 , latex mold of tailfan, $4.9 \times$.

v. 1908 Palaeocaris lansboroughi Peach, p. 55, pl. 8, figs. 8-10.

1911 Palaeocaris landboroughi Peach. Woodward, p. 363.

1932 Palaeocaris praecursor (Woodward). Calman, p. 537, figs. 1, 2.

$1962 b$ Palaeocaris praecursor (Woodward). Brooks, p. 249.

1969a Palaeocaris praecursor (Woodward). Schram, p. 220, table 1.

Lectotype (here designated).-GSL 30213-14 (fig. 54a); Shipley Hall, 11/4 miles NW of Ilkestone, Derbyshire; Clay Ironstone, top Modiolaris Zone, Middle Coal Measures.

Diagnosis.-Since there is only one species, the diagnosis is the same as for the genus.

Description. - The cephalic shield is plain and unornamented, but has a somewhat sigmoid ventral margin. The first antenna has a 
three segment peduncle with the first and third segments subequal and the second somewhat shorter than either of these. The second antenna has at least three segments in its peduncle (with the same proportions as the peduncular segments of the first antenna) and an oval scaphocerite. Nothing is known concerning the mouthparts.

The first thoracomere is reduced. All the rest of the body segments are decorated with three to four laterally directed faint ridges on each segment. The thoracic pleura are rounded. The pereiopods (GSL 30213, fig. 54a) consist of two short protopodal segments, an annulate exopod, and an endopod with a moderately long ischium and merus, a short carpus, and propodus and dactylus of unknown size.

The pleura of the first five abdominal segments are somewhat pointed. The pleopods (GSL 30213, fig. 54a) are biramous and consist of long, thin annulate rami. The telson is rectangular (GSL $\mathrm{Za2945)}$ in outline but bilobed terminally. The lateral margin of the telson was armed with 12 to 13 moveable spines; the pair on the terminus is somewhat larger than any of the others. The telson margin was thickened laterally (GSL 30215).

Remarks.-Although this species has been treated for years as a form of the genus Palaeocaris, a close examination of the morphology of the appendages indicates that it is quite unrelated to Palaeocaris. Consequently, I have had to return to the use of Woodward's original genus, Praeanaspides. The annulate thoracic exopods and the annulate pleopods indicate the affinities to the American Squillites spinosus as elucidated by Schram and Schram (1974).

There are significant differences between Squillites and Praeanaspides that justify separate genera. Praeanaspides has a markedly reduced first thoracomere, while Squillites is only slightly so. Praeanaspides has biramous annulate pleopods which are rather long and delicate, and Squillites has uniramous, somewhat shorter and thicker pleopods. The telson of Praeanaspides is rectangular in outline and the uropod has a diaresis, while that of Squillites is spatulate and there is no diaresis on the uropod.

The reduced first thoracomere in Praeanaspides is an advanced character and almost approaches an anaspidacean condition. The biramous pleopods, however, are more primitive than the uniramous ones of Squillites. In retrospect, though, it seems clear that there was a convergence in at least some of the Paleozoic palaeocaridaceans toward ar: anaspidacean condition. 


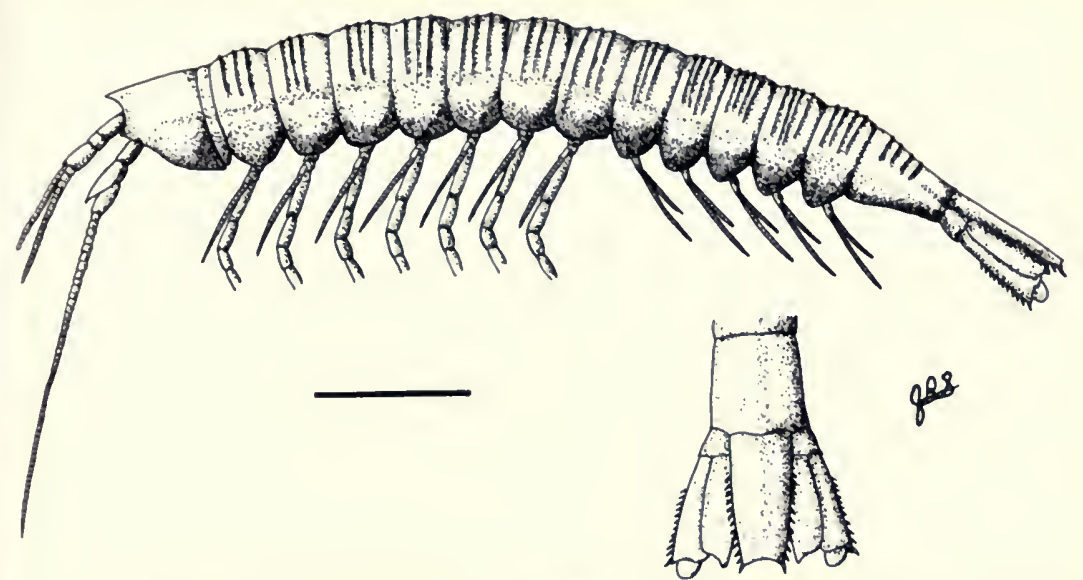

FIG. 55. Praeanaspides praecursor Woodward, 1908. Reconstruction, scale $5 \mathrm{~mm}$.

Measurements are given in Table 21, a reconstruction in Figure 55 .

TABLE 21. Measurements in centimeters of some representative specimens of Praeanaspides praecursor. ${ }^{\star \star}$ indicates lectotype.

$\begin{array}{lcccc}\text { specimen } & \text { cephalon } & \text { thorax } & \text { abdomen } & \text { telson } \\ \text { GSL 30213** } & .35 & 1.64 & 1.50 & \\ \text { GSL 30215 } & .20 & 1.50 & 1.55 & .48 \\ \text { GSL Za 2945 } & & 1.19 & .95 & .30 \\ \text { GSL Za 3001 } & .26 & 1.03 & 1.0 & .45 \\ \text { GSL Za 3003 } & & 1.20 & & \\ \text { GSE 4762 } & & 1.22 & 1.08 & \\ \text { In 29026 } & & & & .54 \\ \overline{\mathrm{x}} & .27 & 1.30 & 1.21 & .44\end{array}$

Superorder: uncertain

Joanellia gen. nov.

Type species.-Palaeocrangon elegans Peach, 1883. River Esk, Glencartholm, Dumfriesshire; Glencartholm Volcanic Beds, Lower Oil Shale Group, Calciferous Sandstone Series. 


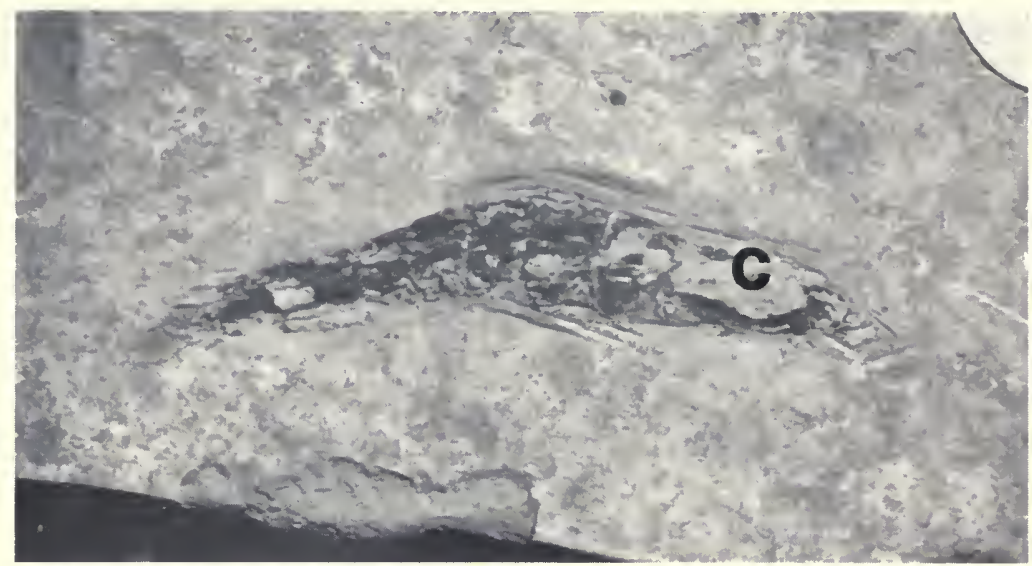

FIG. 56. Joanellia elegans (Peach), 1883. GSE 5838, lectotype, with carapace (c), $2.7 \times$.

Diagnosis. - Small malacostracan with very long last abdominal segment(s). Second pleomere large and subtriangular. Tail fan elaborate. Carapace subtriangular.

Etymology.-Named after my wife, Joan Matthews Schram.

Joanellia elegans (Peach), 1883, Figures 56, 57.

v*. 1883 Palaeocrangon elegans Peach, p. 515, pl. 28, figs. 8-8a.

1903 Palaeocrangon elegans Peach. Peach and Horne, p. 846.

v. 1908 Crangopsis robusta Peach, p. 78, pl. 12, figs. 8-12.

? 1908 Crangopsis minuta Peach, p. 80, pl. 11, figs. 16-18.

v. 1908 Crangopsis elegans (Peach). Peach, p. 81, pl. 11, figs. 9-10.

1911 Crangopsis robusta Peach. Woodward, p. 363.

1911 Crangopsis elegans (Peach). Woodward, p. 363.

? 1911 Crangopsis minuta Peach. Woodward, p. 363.

1969 Anthracophausia robusta (Peach). Brooks, p. R343.

? 1969 Anthracophausia minuta (Peach). Brooks, p. R343.

1969a Anthracophausia robusta (Peach). Schram, p. 215, table 1.

? 1969a Anthracophausia minuta (Peach). Schram, p. 215, table 1.

1969 a Crangopsis elegans (Peach). Schram, p. 216.

Lectotype.-GSE 5838 (fig. 56); River Esk, Glencartholm, 11⁄2 miles below Langholm, Dumfriesshire; Glencartholm Volcanic Beds, Calciferous Sandstone Measures.

Diagnosis. - Since there is only one species, the diagnosis is the same as that of the genus.

Description.-Of the few specimens of this species, only GSE 5838 (fig. 56) and GSE 5839 effectively preserve any of the perti- 
nent anatomy. GSE 5838 is the best specimen and has a carapace $7.5 \mathrm{~mm}$. and the abdomen about $20 \mathrm{~mm}$. in length.

The carapace is somewhat triangular with the ventral posterior area greatly developed. The first, third, fourth, and fifth pleomeres are subequal. The second pleomere is greatly enlarged over these, has a pointed pleuron, and is subtriangular in shape. The posterior portion of the abdomen is greatly elongate and serves to mark this animal from all malacostracans. The preservation on the available specimens is such that it must be studied under xylene or alcohol immersion.

Figure 57 presents a schematic diagram of GSE 5838 and 5839. From the anterior part of segment six, or the posterior of segment five, a long appendage extends posteriad. At about the point of what appear to be the uropods there appears to be a suture (or it may merely represent a point of weakness in the cuticle). The body
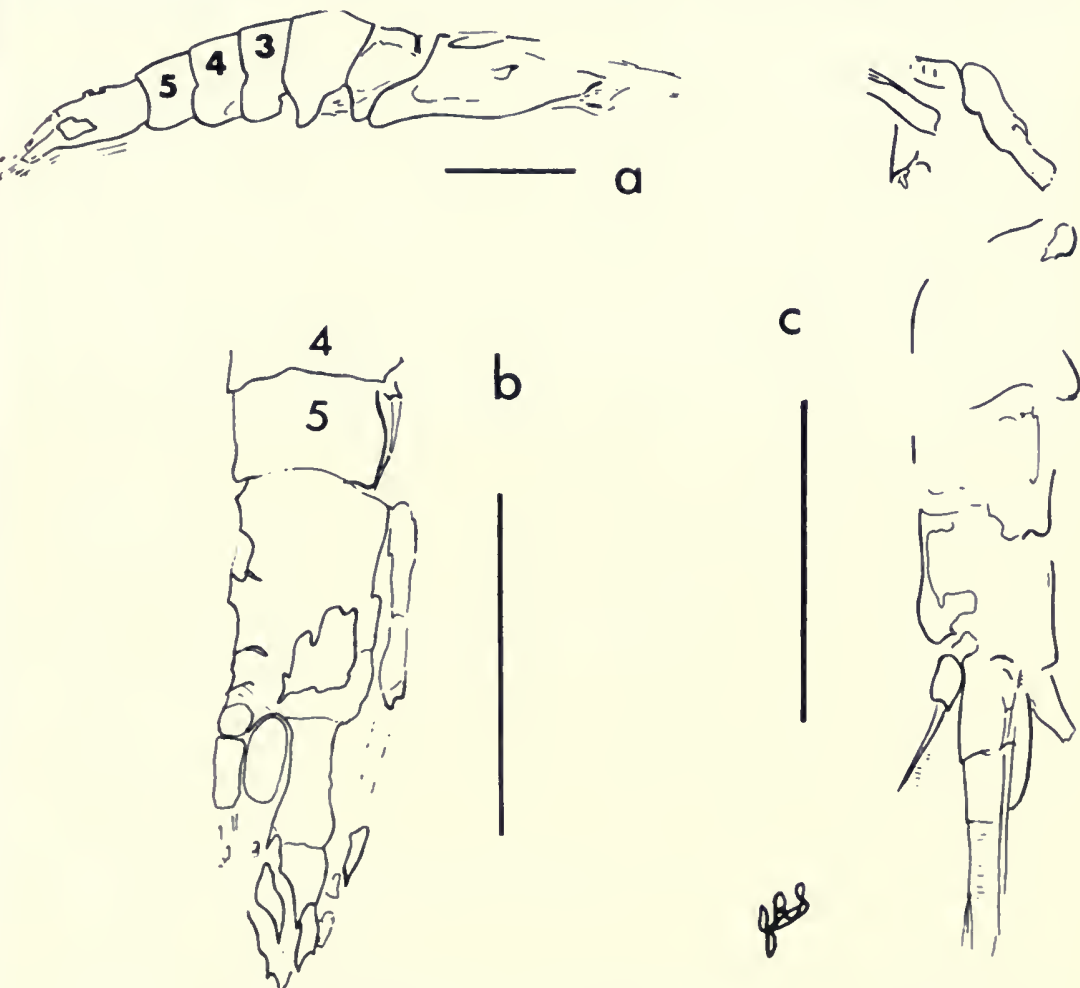

C

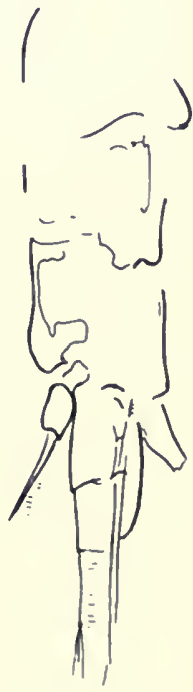

FIG. 57. Joanellia elegans (Peach) 1883. Outline diagrams of selected specimens. A, GSE 5838, lectotype; B, detail of tailfan of GSE 5838; C, GSE 5839. Scale $5 \mathrm{~mm}$. 
extends posteriad of this point to another suture. Beyond this last point there is a large caudal spine, or perhaps a "telson." Attached to this "telson" are a pair of large sculptured lobes. Also associated with this "telson" are another pair of lobes which may be either part of the uropods or another set of caudal lobes.

Remarks. - This is one of the most confusing and mysterious crustaceans to come to light yet. Because of the nature of the preservation, effective interpretation of the anatomy is difficult. Are we dealing in that last segment with one long sixth segment? Or is this a remnant fusion of the sixth and seventh segment? Or is there a distinct seventh segment beyond the uropods? Is the anterior set of "caudal lobes" part of the "first uropod" or remnants of a second set of uropods associated with the seventh segment? Or is there a true set of caudal lobes on the "telson"?

These questions are all unanswerable at present. Therefore, I have only recorded the anatomy and not ventured an interpretation and reconstruction at this time.

The type material of Crangopsis minuta Peach, 1908 is lost. This species came from Coomsden Burn, Northumberland, locality 34 . It was compared by Peach with his $C$. robusta which I have placed in Joanellia elegans. Peach calls attention to the sixth pleomere being "especially long and narrow," which would fit J. elegans. Examination of the collections at Leeds, however, shows that true Crangopsis is known from this locality as well. So there must be some reservation on placing $C$. minuta in $J$. elegans without the types to examine. 


\section{MATERIALS}

Species are listed alphabetically by genus. Specimen numbers use the prefixes indicated on p. 26. Localities from which specimens come are indicated by the bold-faced locality number from the register of localities, p. $5 .{ }^{*}$ indicates holotypes. ${ }^{\star}{ }^{*}$ indicates lectotypes. Where possible, unbroken suites of numbers are indicated with a hyphen.

Anthracocaris scotica (Peach)

1. GSE $5002,5803^{\star \star}$-5811

E 13491-13493

K $02-85 \mathrm{MO}$

Anthracophausia dunsiana Peach

1. GSE $5010,5814,5819^{* *}-5822,5824,5840(?), 5842,5869,5870,10078$

GSL M2578c

I 519

5. $\mathrm{R} 1887.25 .1021-1885.25 .1028, \quad 1887.25 .1030-1887.25 .1032, \quad 1887.25 .1060-$ 1887.25.1063, 1957.1.5101

A 2249

6. GSE 5867,5868

GSL 35039

R $1911.62 .8616,1911.62 .8617,1957.1 .5102-1957.1 .5109$

A 2255

16. GSE ER7970-ER7972, ER7976-ER7978, ER7980

33. GSL R1682, R1683

59. GSL Za2957, Za2958

61. GSL RAE 1292

63. GSL Za2939-Za2941

Bairdops elegans (Peach)

1. GSE $5873,5876,5877,5879 * *-5884,5886$

GSL M566f, M557f, M1399c

L 9284,9287

A 2251

E 13488,13490

4. GSE $5885,5887-5889$ 
Belotelson traquairi (Peach)

1. GSE $5008,5009,5823,5825-5827 * *, 5828-5831,5900$

GSL M553f

L 9284

A 2254

8. GSE $5813,5815-5818$

GSL M788d, M799d

43. L $8184($ ?)

Crangopsis eskdalensis Peach

1. GSE $5007^{* *}, 5840,5841,5843-5846,5848$

GSL M585f

R 1911.62.8597, 1911.62.8618, 1911.62.8619, 1957.1.5110, 1958.1.2635, 1958.1.2636

L 1124

A $1986,2017-2019,2248$

E 13496-13500, 13502

K 02-85MR

10. GSE M1642c(?)

22. GSE T712g, T714g-T716g

34. poorly preserved, identification tentative

GSL R1438, R1443, R1507, R1508, R1512, R1514, R1516, R1517, R1543, R1565, R1605, Ra

Crangopsis socialis (Salter)

13. GSE 12027

14. E Several drawers of unnumbered slabs of mostly Waterstonella grantonensis but with some $C$. socialis as well.

15. GSE 5847,8735

GSL $87432^{*}$

R 1885.22.1, 1957.1.5111, 1957.1.5112, 1958.1.2637 -1958.1. 2646, 1958.1.2648, 1958.1.2650, 1958.1.2651, 1958.1. 2677, 1969.15.1, 1969.15 .2

A 2003-2011

E 13495

P 32071-32073

16. GSE 7972, 7981-83, 7985, 7987-94, 7996, 7997, 7999.

17. GSE 4666-4669

21. GSE some small, poorly preserved material, probably this species

45. GSL $47 / 31$

Joanellia elegans (Peach)

1. GSE 5838**

8. GSE 5839

GSL M762d

34. GSL $87431, \mathrm{R} 1446$

36. GSL R1586, R1587 
Minicaris brandi Schram

20. GSE $13056^{*}$

Palaeocaris retractata Calman

52. R 1911.6.14

In $29012 *-29017,29019,29020,29022-29025$

61. GSL RAE 1292(?)

71. BU 733

Kallidecthes eagari Schram

91. In $31865,31866,31991,36143,36144,36146,36148^{*}, 37961,41769,61401$

"Perimecturus" pattoni Peach

5. $\mathrm{R} 1887.25 .1059$

Perimecturus parki (Peach)

1. GSE $4663,4664,5006,5871,5872,5874,5875,5878,5881,5890-5896^{* *}$, 5897-5904, 5906, 10080

GSL M422c(?), M541f

R 1958.1.2649

A 1978,1979

E $13485,13486,13489(?), 13494,13505-13507,14436$

I 891 and In 35330 (counterparts)

?13. GSE 4665 (see comments on locality 13)

K G 74-6JT

Pleurocaris annulatus Calman

52. I $13813,13814,1541$ (?)

In $29008^{*}-29010$

Praeanaspides praecursor Woodward

3. GSE 4762

56. GSL 30213-14**, 30215-16, 30217, 30218-19, 30251, Za2945, Za2990, Za3000-1 I 8840

Pseudogalathea macconochiei (Etheridge)

1. GSE 5907, 5912-5914

GSL M603f, M678c, M2925f, M2969c

4. GSE $5079,5908,5909,5911 * *$

R 1957.1.5051, 1957.1.5052, 1957.1.5071

A $1967-1972,1974-1977,1987,1988$

OE 2046

K 02113a-02113d, 02-85MT

19. GSE M4276e-4278e

33. GSL R1707

34. GSL R1447, R1513, R1518, R1519, R1522, R1523, R1526, R1545, R1546, R1549, R1670, R1671, R1702

Pseudotealliocaris etheridgei (Peach)

1. GSE 5915-5918**, 5919-5929, M438c

GSL M2292c, M2521c(?), M3344c 
R 1881.39.4, 1957.1.5014-1957.1.5018, 1958.1.2652

\section{9281}

A 2252,2253

E 13470-13477

K 1401(?), 1402, 2185, 2186, 2446, 2448, 2630, 4855

4. $\quad \mathrm{R} 1957.1 .5051,1957.1 .5052$

A 1988

5. R 1887.25.1033-1887.25.1036, 1887.25.1059

8. GSE 5943

9. GSE 5940,5942

R 1969.11

11. GSE 5931(?)

Pygocephalus cooperi Huxley

3. GSE JS19265, JS19269(?), M614f, 4983

D Acs 66

18. R 1957.1.5098

35. A 2012-2015, 2140-2143

41. GSL $25425-25428$

42. L 10221 *

43. L 7094, 8195

In 18580,18568

Rochdale Museum 802050201

44. L 6964-6966

52. GSL $23453-23461,26138$

R 1911.6.13

A two unnumbered specimens

$\mathrm{K} \mathrm{40-21a/b}$

I 1536,14447

53. GSL $49044-49045$

54. GSL $5338,49642,49643$

BU 542

56. I 992

57. GSL 30242 (missing)

59. GSL 30284-5, Za2954, Za3058-Za3060

65. GSL At4990

72. In 41511

Pygocephalus dubius (Prestwich)

6. GSE 4757-4761, 5832-5837

GSL $88797-88801,35037,35038$, T2764b

R 1884.46.177a-c, 1904.99.2, 1911.62.8606-1911.62.8610, 1957.1.15081957.1.1510, 1957.1.5081-1957.1.5097, 1957.1.5114, 1957.1.5115, $1958.1 .2634,1964.30 .331$

A 1985,2202

K 01-53pd, 01-53pc, G746HC-G746HJ, G746HM-G746HR 
7. GSL 88796

R 1974.14

31. GSL BG1454-5

32. GŚL YAF72

37. GSL 87030,87031

51. GSL 54398.9*

55. L 8406

58. GSL ZL1433-4, ZL 1855, ZL 1860, ZL 2146-ZL 2148

60. GSL $30286-7$

62. GSL ZL 2124

64. GSL 30251, 30255, 30256, 30258-30261, 30263, 30264, 30268-30273, 30275-30283, Za3004-Za3039, Za3041, Za3043-Za3057, Za3062Za3074, Za3079, Za3090

66. GSL DF848, DF849

67. GSL Sy632-2a

68. GSL Bal277

69. GSL Bu2677

70. NMW 70.17G.14a/b

Sairocaris elongata (Peach)

1. GSE $4662,5793-5795 * *, 5796-5802$

GSL 14 unnumbered specimens

A 1 unnumbered specimen

E 13487, 13503, 13504

K 1577

Tealliocaris woodwardi (Etheridge)

2. GSE 10079, 10081

GSL M537f

4. GSE 5946-5948, 5952, 5953

10. GSE M1635c·M $1638 \mathrm{c}$

E 13469

11. GSE $5930-5939,5947-5950^{* *}, 5951,5952,9651$

GSL M4801e, M4809e, M4824e, M4846e, M4853e, 22746

R 1904.41.1, 1904.41.2, 1905.140, 1908.12.2, 1911.62.8689-1911.62.8718, $1911.62 .8682-1911.62 .8688,1957.1 .5019-1957.1 .5028,1957.1 .5030-$ 1957.1.5050, 1957.1.5053-1957.1.5070

L 7367

A $1960-1965,2203,2204$

E 13463-13468, 19901

P 32056-32070

OE 2047-2051

12. GSE 5944,5945

20. GSE T448d-T458d, T466d

33. GSL Peach figured specimens from this locality, but they are lost. 
Waterstonella grantonensis Schram

13. GSE 12027, 13051-13053*, 13054, 13055 (and innumerable other blocks of specimens)

R 1958.1.2669-1958.1.2672

A $2263 / 1-2$

GI 43.753

14. R 1964.30.332, 1975.11.1-1975.11.3

E several slabs collected by the Sedgwick Club

K G74-6JT 


\section{REFERENCES}

ANDERSON, D. T.

1973. Embryology and phylogeny in annelids and arthropods. Pergamon Press. $495 \mathrm{pp}$.

BEURLEN, K.

1930. Vergleichende Stammensgeschichte Grundlagen Methoden, Probleme unter besonderer Burücksichtungen der hüheren Krebse. Fortschr. Geol. Palaeontol., 8 , pp. 317-464.

BOAS. J. E. V.

1883. Studien über die Verwandtschaftsbeziehungen des Malakostraken. Morphol. Jahbr., 8, pp. 485.579.

BOLTON, H.

1905. Notes on the geological horizon and paleontology of the "Soapstone Bed" in the Lower Coal Measures, near Colne, Lancashire. Geol. Mag., ser. 5, 2, pp. 433-444.

BRoOKs, H. K.

1962a. On the fossil Anaspidacea, with a revision of the classification of the Syncarida. Crustaceana, 4, pp. 229-242.

1962b. The Paleozoic Eumalacostraca of North America. Bull. Amer. Paleontol., 44, pp. 163-338.

1969. Eocarida, Syncarida, and Palaeostomatopoda, pp. R332-R359 and R533-R535. In Moore, R. C. ed., Treatise on invertebrate paleontology, Part R, Arthropoda 4.

BROWN. T.

1861. Notes on the Mountain Limestone and Lower Carboniferous rocks of the Fifeshire coast from Burntisland to St. Andrews. Trans. Roy. Soc. Edinburgh, 22, pp. 385-404.

Calman, W. T.

1897. On the genus Anaspides and its affinities with certain fossil Crustacea. Trans. Roy. Soc. Edinburgh, 38, pp. 787-802.

1904. On the classification of the Malacostraca. Ann. Mag. Nat. Hist., ser. 7, 13, pp. 144-158.

1911a. On Pleurocaris, a new crustacean from the English Coal Measures. Geol. Mag., ser. 5, 8, pp. 156-160.

1911 b. On some Crustacea of the division Syncarida from the English Coal Measures. Geol. Mag., ser. 5, 8, pp. 488-495. 
1932. Notes of Palaeocaris praecursor (Woodward), a fossil crustacean of the division Syncarida. Ann. Mag. Nat. Hist., ser. 10, 10, pp. 537-541.

1933. On Anthracocaris scotica (Peach), a fossil crustacean of the Lower Carboniferous. Ann. Mag. Nat. Hist., ser. 10, 11, pp. 562-565.

Calver, M. A.

1969. Westphalian of Britain. Compte Rendu 6e Congrés Intern. Strat. Geol. Carbonif., Sheffield 1967. 1, pp. 233-254.

Caruthers, R. G.

1927. The oil shales of the Lothians, Part I, 3rd ed. Mem. Geol. Soc. Scotland, pp. 1-114.

Chappuis, P. A.

1915. Bathynella natans and ihre Stellung im System. Zool. Jahrb., 40, pp. 147-176.

Copeland, M. J.

1957. The arthropod fauna of the Upper Carboniferous rocks of the Maritime Provinces. Geol. Surv. Canada, Mem. 286, 110 pp.

CRAIG, G. Y.

1965. The geology of Scotland. Oliver and Boyd, Edinburgh and London. $556 \mathrm{pp}$.

DANA, J. D.

1852. The United States Exploring Expedition, Vol. XIII, Crustacea. 1,618 pp.

DIX, E.

1930. An arthropod (Anthrapalaemon cf. russelianus (Salter)), from the north Staffordshire coalfield. Naturalist, (March), pp. 103-104.

Edwards, W. and C. J. StubBelfield

1948. Marine bands and other faunal marker horizons in relation to the sedimentary cycles of the Middle Coal Measures of Nottinghamshire and Derbyshire. Q. Jour. Geol. Soc., London, 103, pp. 209-260.

ETHERIDGE, R.

1877. On the occurrence of a macrurous decapod (Anthrapalaemon? woodwardi sp. nov.) in the Red Sandstone, or lowest group of the Carboniferous formation in the southwest of Scotland. Q. Jour. Geol. Soc., London, 33. pp. 863-878.

1879. On the occurrence of the genus Dithyrocaris in the Lower Carboniferous, or Calciferous Sandstone Series, of Scotland, and that of a second species of Anthrapalaemon in these beds. Q. Jour. Geol. Soc., London, 35, pp. 464-474.

GEORGE, T. N.

1957. Lower Carboniferous palaeogeography of the British Isles. Proc. Yorks. Geol. Soc., 31, pp. 227-318.

Hessler, R. R.

1969. Peracarida, pp. R360-R393. In Moore, R. C., ed., Treatise on invertebrate paleontology, Part, R, Arthropoda 4.

HuXLeY, T. H.

1857. Description of a new crustacean (Pygocephalus cooperi, Huxley) from the Coal Measures. Q. Jour. Geol. Soc., London, 13, pp. 363-369. 
1862. On a stalked eyed crustacean from the Carboniferous strata near Paisley.

Q. Jour. Geol. Soc., London, 18, pp. 420-422.

JONES, T. R. and H. WOODWARD

1888-1899. British Paleozoic Phyllopoda. Paleontol. Soc. Mem., 41, 46, 52, and 53. 1899. Contributions to fossil Crustacea. Geol. Mag., (4), 6, pp. 388-395.

LANG, $\mathrm{K}$.

1956. Neotanaidae nov. fam., with some remarks on the phylogeny of the Tanaidacea. Ark. Zool., ser. 2, 9, pp. 469-475.

Lumsden, G. I., W. Tullach, M. F. Howells, and A. Davis

1967. The geology of the neighborhood of Langholm. Mem. Geol. Surv. Scotland, $255 \mathrm{pp}$.

MANTON, S. M.

1973. Arthropod phylogeny-a modern synthesis. Jour. Zool., 171, pp. 111-130.

MatThews, S. C.

1973. Notes on open nomenclature and on synonymy lists. Paleontology, 16, pp. 713-719.

MEEK, F. B. and A. H. WORTHEN

1865. Notice of some new types of organic remains from the Coal Measures of Illinois. Proc. Acad. Nat. Sci., Philadelphia, 18, pp. 46-51.

Mitchell, G. H. and W. Mykura

1962. Geology of the neighborhood of Edinburgh, 3rd ed. Mem. Geol. Surv. Scotland, $159 \mathrm{pp}$.

PACKARD, A. S.

1886. On the Syncarida, a hitherto undescribed synthetic group of extinct malacostracous Crustacea. Mem. Nat. Acad. Sci., Washington, 3, pp. 129-133.

PEACH. B. N.

1882. On some new Crustacea from the Lower Carboniferous rocks of Eskdale and Liddesdale. Proc. Roy. Soc., Edinburgh, 30, pp. 73-91.

1883. Further researches among the Crustacea and Arachnida of the Carbonferous rocks of the Scottish border. Proc. Roy. Soc., Edinburgh, 30, pp. 511-529. 1908. A monograph on the higher Crustacea of the Carboniferous rocks of Scotland. Geol. Surv. Great Britain, Paleontol. Mem. 1908, 82 pp.

1914. On some Carboniferous arthropods, with description of a new genus of myriapod. Proc. Roy. Phys. Soc., 19, pp. 142-148.

PEACH, B. N. and J. HORNE

1903. The Canonbie coalfield: its geological structure and relations to the Carboniferous rocks of the north of England and central Scotland. Trans. Roy. Soc., Edinburgh, 40, pp. 835-878.

Prestwich, J.

1840. On the geology of the Coalbrookdale. Trans. Geol. Soc., London, ser. 2, 5, pp. 413-495. 


\section{RHODES, G. H. T. and A. A. WILSON}

1957. The arthropod species Anthrapalaemon dubius and related forms. Jour. Paleontol., 31, pp. 1,159-1,166.

\section{Richter, R.}

1948. Einführung in der Zoologische Nomenklatur (2nd ed.). Kramer, Frankfurt a.M. 252 pp.

ROLFE, W. D. I.

1961. A syncarid crustacean from the Keel beds (Stephanian) of Warwickshire. Paleontol., 4, pp. 546-551.

1963. Morphology of the telson in Ceratiocaris ? cornwallensis (Crustacea: Phyllocarida) from Czechoslovakia. Jour. Paleontol., 37, pp. 486-488.

1969. Phyllocarida, pp. R296-R331. In Moore, R. C., ed., Treatise on invertebrate paleontology, Part R, Arthropoda 4.

SAlter, J. W.

1861a. In Brown, T., Notes on the Mountain Limestone and Lower Carboniferous rocks of the Fifeshire coast from Burntisland to St. Andrews. Trans. Roy. Soc., Edinburgh, 22, pp. 385-404.

$1861 \mathrm{~b}$. On some higher Crustacea from the British Coal Measures. Q. Jour. Geol. Soc., London, 17, pp. 528-533.

1863a. On some fossil Crustacea from the Coal Measures and Devonian rocks of British North America. Q. Jour. Geol. Soc., London, 19, pp. 75-80.

$1863 \mathrm{~b}$. On a new crustacean from the Glasgow coalfield. Q. Jour. Geol. Soc., London, 19, pp. 519-521.

SARS, G. O.

1885. Report on the schizopods collected by H. M. S. Challenger during the years 1873-76. Challenger Reports, Zoology 13, pp. 1-288.

SCHRAM, F. R.

1969a. The stratigraphic distribution of the Paleozoic Eumalacostraca. Fieldiana: Geol., 12, pp. 213-234.

1969b. Some Middle Pennsylvanian Hoplocarida and their phylogenetic significance. Fieldiana: Geol., 12, pp. 235-289.

1973. On some phyllocarids and the origin of the Hoplocarida. Fieldiana: Geol., 26, pp. 77-94.

1974a. Mazon Creek caridoid Crustacea. Fieldiana: Geol., 30, pp. 9-65.

1974b. North American Paleozoic Peracarida. Fieldiana: Geol., 33, pp. 95-124.

SChram, J. M. and F. R. SChram

1974. Squillites spinosus Scott 1938 (Syncarida: Malacostraca) from the Mississippian Heath Shale of Central Montana. Jour. Paleontol., 48, pp. 95-104.

TAIT, D.

1925. Notice of a shrimp bearing limestone in the Carboniferous Sandstone Series at Granton near Edinburgh. Trans. Edinburgh Geol. Soc., 11, pp. 131-134.

VANDENBERghe, A.

1960. Un arthropode du terrain houiller de la Loire Eilecticus pruvosti nov. sp. Bull. Soc. Geol. France, ser. 7, 2, pp. 690-692. 
VAN DER HEIDE, S.

1951. Les arthropode du terrain houiller du Limbourg Meridinal (excepte les scorpions et les insectes). Mededeelingen van de Geol. Stichtung. wer. C-IV-3, no. $5,84 \mathrm{pp}$.

Van Straelen. V. and G. Schmitz

1934. Crustacea Phyllocarida., In Quenstedt, W. ed., Fossilium Catalogus. pars. 64. W. Junk, Berlin. 246 pp.

WOODWARD, H.

1867. Notes on some fossil Crustacea and a chilognathous myriapod from the Coal Measures of the west of Scotland. Trans. Glasgow Geol. Soc., 2, pp. 234-248.

1879. On Necroscilla wilsoni a supposed stomatopod crustacean from the Middle Coal Measures, Cossall, near Ilkeston. Q. Jour. Geol. Soc., London, 35, pp. 551-552.

1881. Contributions to the study of fossil Crustacea. Geol. Mag., ser. 2, 8, pp. 529-534.

1905. Notes on some Crustacea and two myriapods from the Lower Coal Measures near Colne, Lancashire. Geol. Mag., ser. 5, 2, pp. 437-441.

1907. On the genus Pygocephalus (Huxley) a primitive schizopod crustacean from the Coal Measures. Geol. Mag., ser. 5, 4, pp. 400-407.

1908. Some Coal Measure crustaceans with modern representatives. Geol. Mag., ser. 5, 5, pp. 385-396.

1911. On a large form of Anthrapalaemon from the clay-ironstone nodules of the Middle Coal Measures, Sparth Bottoms, Rochdale. Geol. Mag., ser. 5, 8, pp. 361-366. 

-+2
$-\quad+$ 
Publication 1293 



UNIVERSITY OF ILLINOIS-URBANA

$550.5 \mathrm{FI}$

FIELDIANA, GEOLOGY CHGO

36-41 1976-79

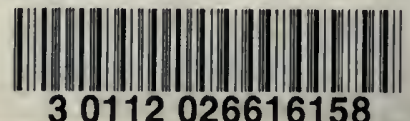

